\title{
Framework for Regional, Coordinated Monitoring in the Middle and Upper Deschutes River Basin, Oregon
}
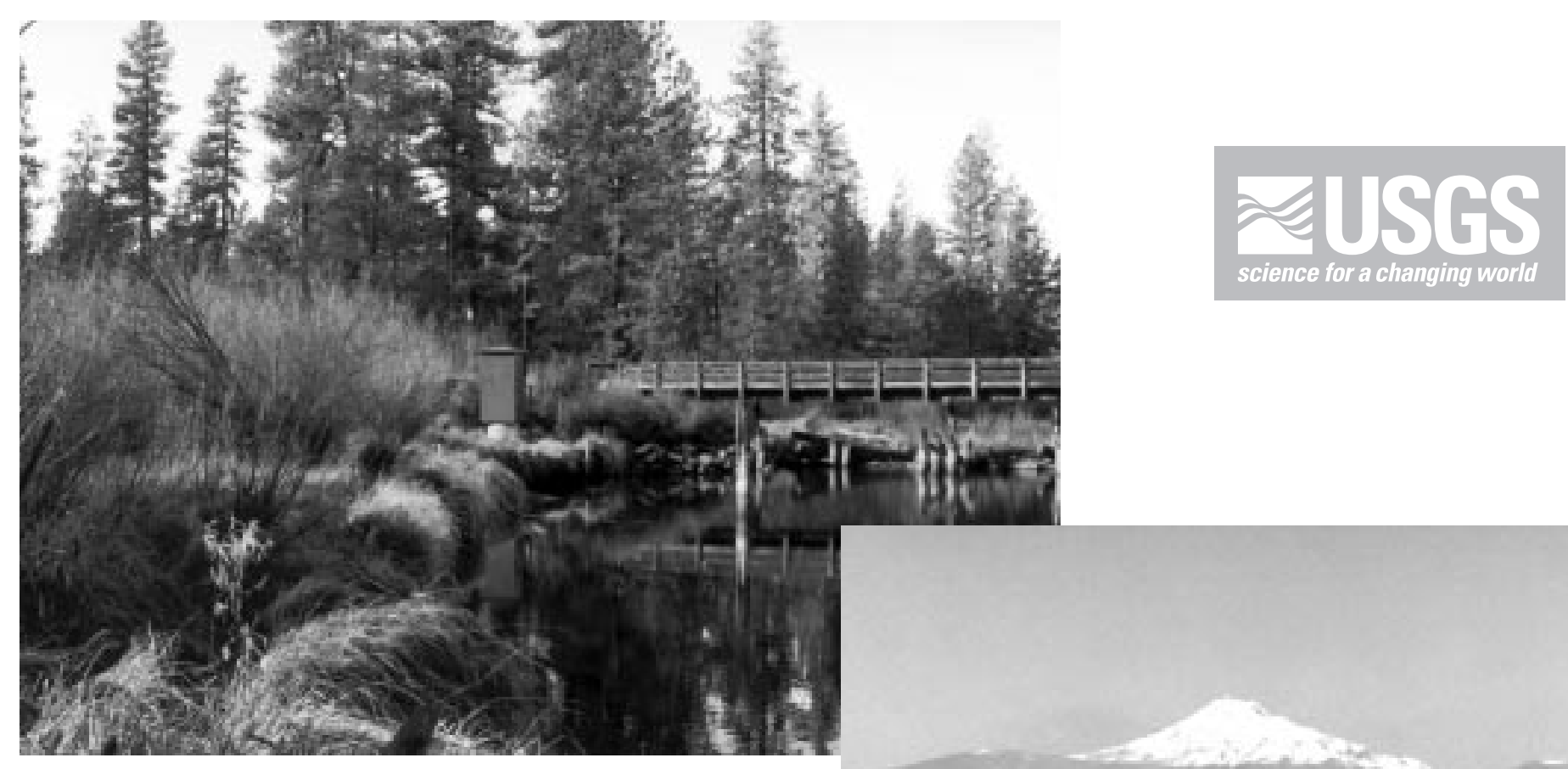

U.S. Department of the Interior U.S. Geological Survey Open-File Report 00-386

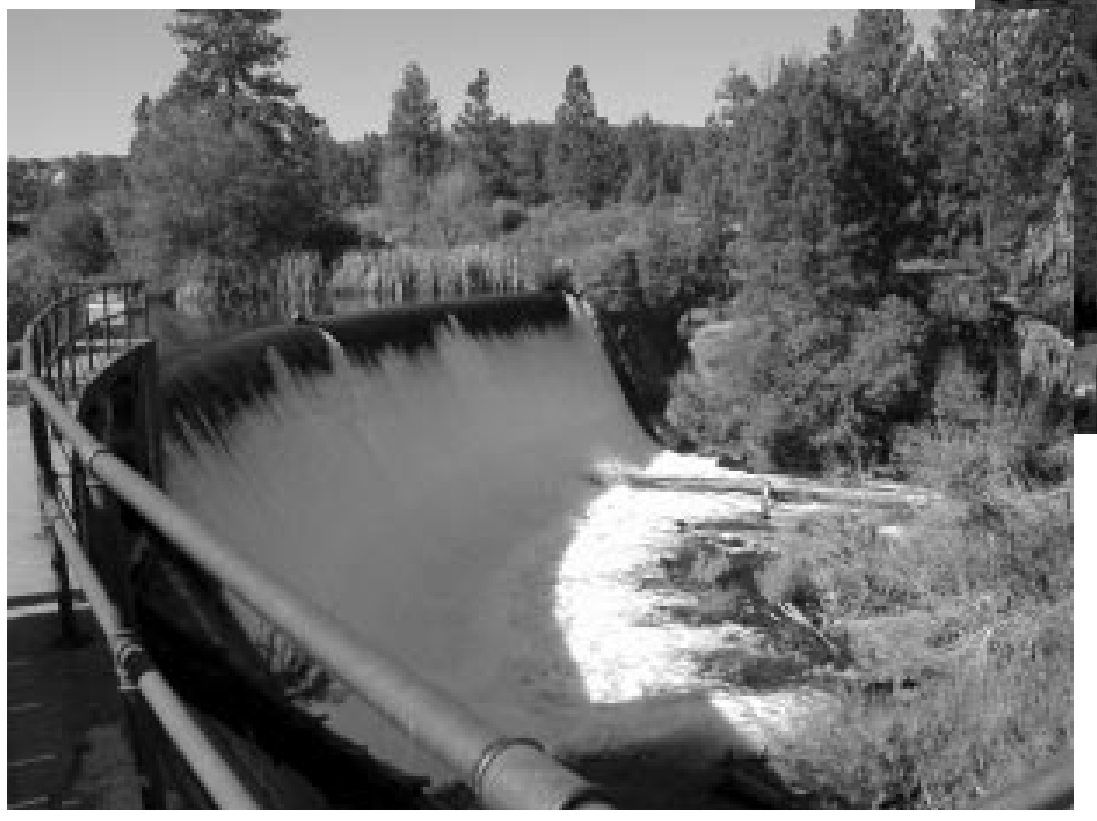

Prepared in cooperation with the UPPER DESCHUTES WATERSHED COUNCIL 


\section{PHOTOGRAPHS}

Front Cover:

Top, Oregon Water Resources Department stream-gaging station on the Deschutes River at Benham Falls.

Middle, Mount Jefferson, Deschutes County, Oregon.

Bottom, Diversion dam, North Unit Canal, Bend, Oregon.

\section{Back Cover:}

Top, Snow Creek.

Bottom, Steelhead Falls on middle Deschutes River upstream from Lake Billy Chinook.

Photographs courtesy of Kyle Gorman, Oregon Water Resources Department, Bend, Oregon. 
U.S. Department of the Interior

U.S. Geological Survey

\section{Framew ork for Regional, Coordinated M onitoring in the Middle and Upper Deschutes River Basin, Oregon}

BY CHAUNCEY W. ANDERSON

Open-File Report 00-386

Prepared in cooperation with the

UPPER DESCHUTES WATERSHED COUN CIL

Portland, Oregon: 2000 


\section{U.S. DEPARTM ENT OF THE INTERIOR}

BRUCE BABBITT, Secretary

\section{U.S. GEOLOGICAL SURVEY}

Charles G. Groat, Director

For additional information contact:

\section{District Chief}

U.S. Geological Survey

10615 S.E. Cherry Blossom Drive

Portland, OR 97216-3159

E-mail: info-or@usgs.gov

Internet: http://oregon.usgs.gov
Copies of this report can be purchased from:

U.S. Geological Survey Branch of Information Servic es B ox 25286, Federal Center Denver, CO 80225-0046

Suggested citation:

Anderson, C.W., 2000, Framew ork for regional, coordinated monitoring in the middle and upper Deschutes River Basin, Oregon: U.S. Geological Survey Open-File Report 00-386, 81 p. 


\section{CONTENTS}

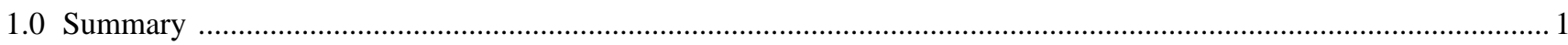

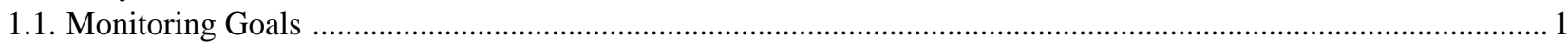

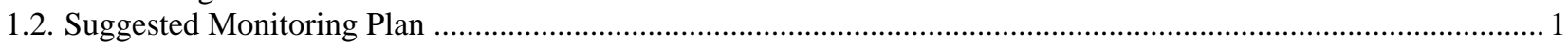

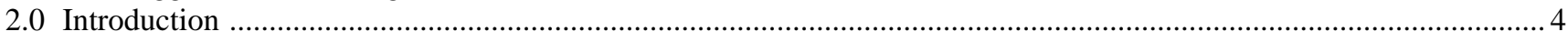

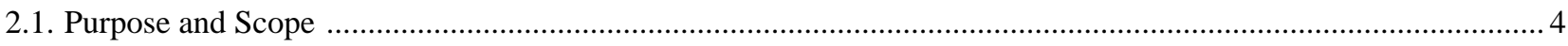

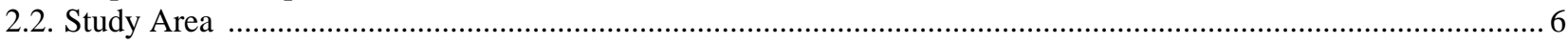

2.3. Water Management in the Upper Deschutes Basin .................................................................................. 9

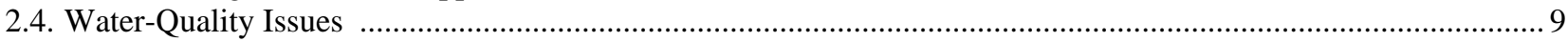

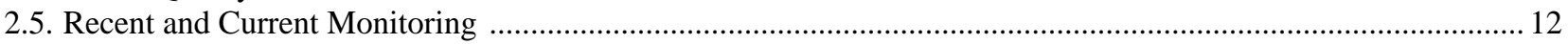

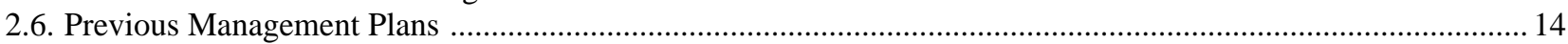

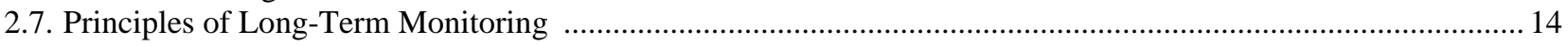

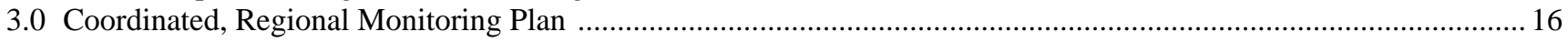

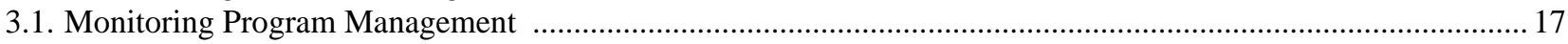

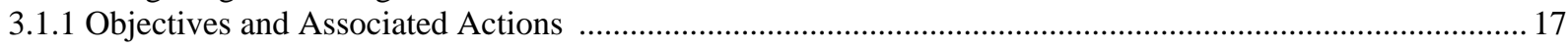

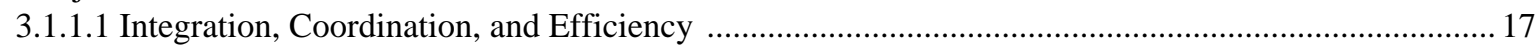

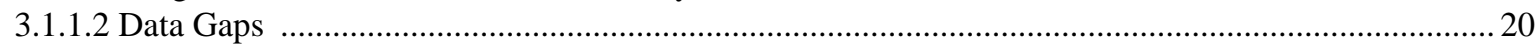

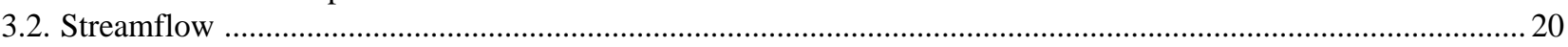

3.2.1 Monitoring Objectives and Associated Actions ................................................................................. 22

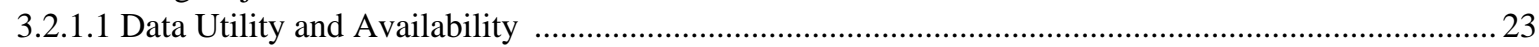

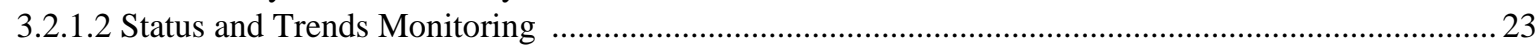

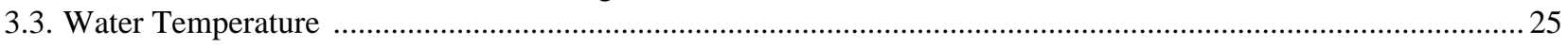

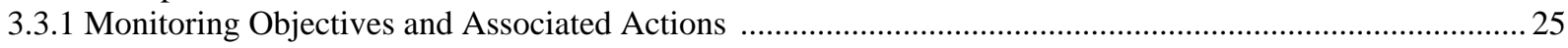

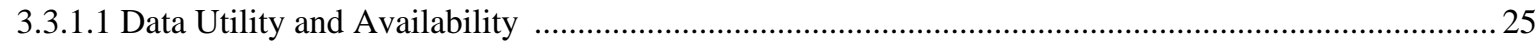

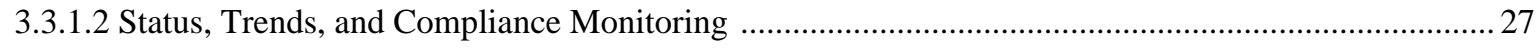

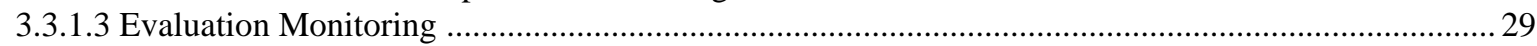

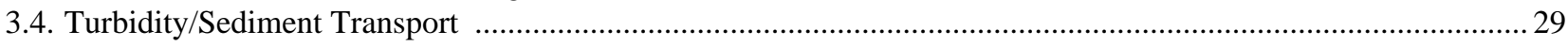

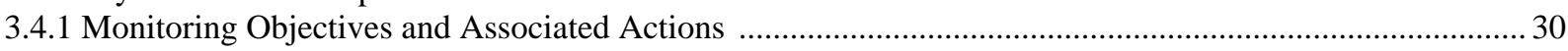

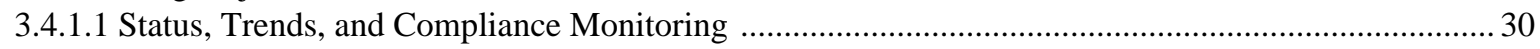

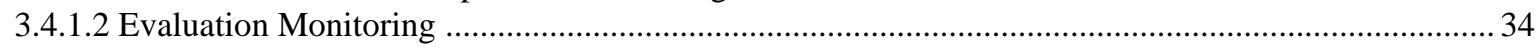

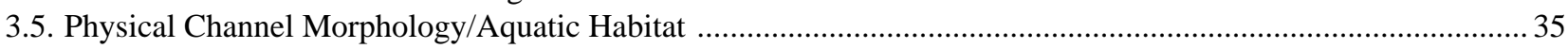

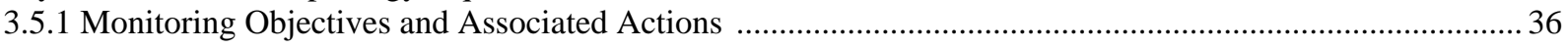

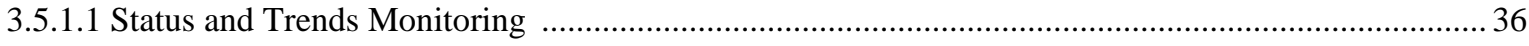

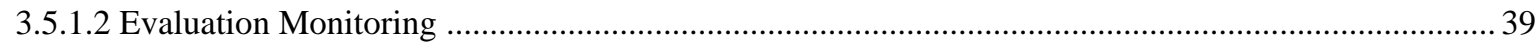

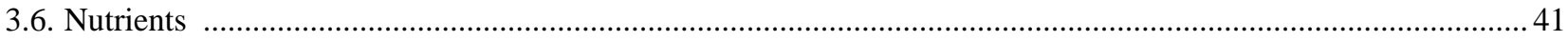

3.6.1 Monitoring Objectives and Associated Actions .................................................................................. 41

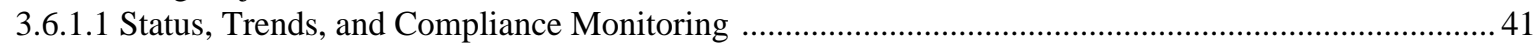

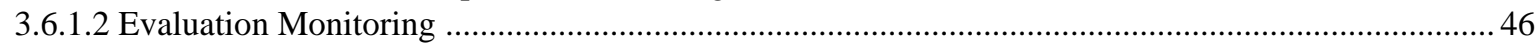

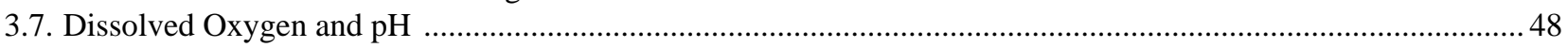

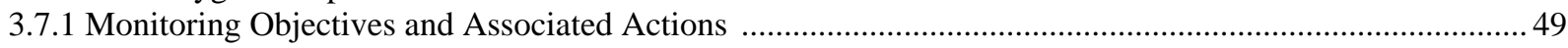

3.7.1.1 Status, Trends, and Compliance Monitoring ……...................................................................... 49

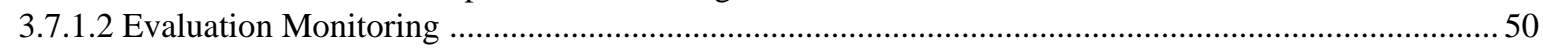

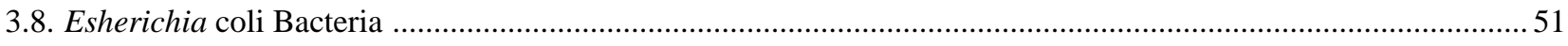

3.8.1 Monitoring Objectives and Associated Actions .................................................................................. 51

3.8.1.1 Status, Trends, and Compliance Monitoring ….......................................................................... 51

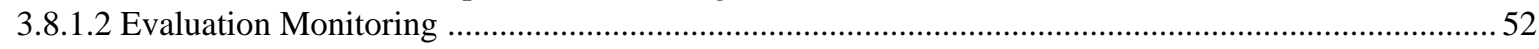

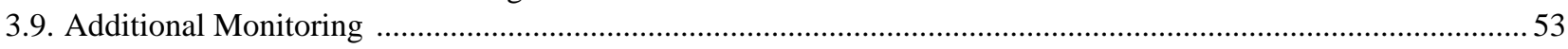

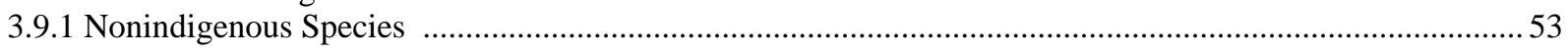

3.9.1.1 Monitoring Objectives and Associated Actions .......................................................................... 54

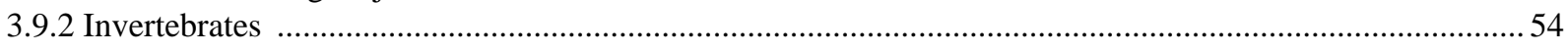

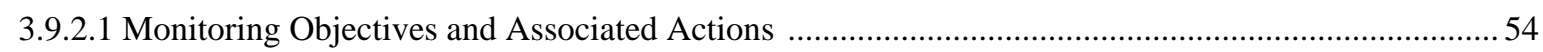

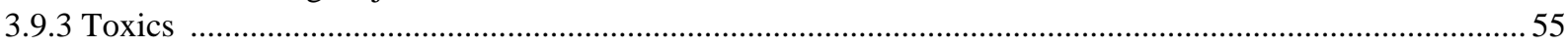

3.9.3.1 Monitoring Objectives and Associated Actions ........................................................................ 55 
4.0 Implementation

4.1. Summary of Proposed Monitoring Actions by Organization …..................................................................56

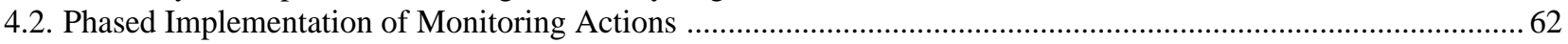

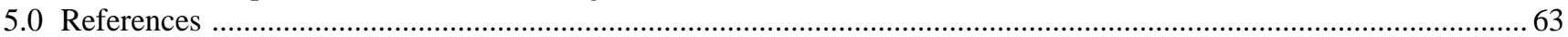

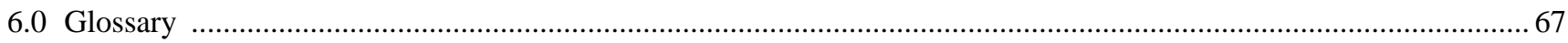

Appendixes:

A. Summary of water-quality objectives and recommendations from previous management plans

B. Quality-assurance terms

\section{FIGURES}

1. -5. Maps showing:

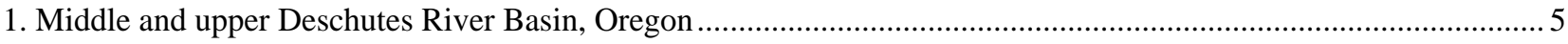

2. Designated reaches for regional monitoring in the upper and middle Deschutes River Basins, Oregon ................... 7

3. Location of active stream-gaging stations in the middle and upper Deschutes River Basin, Oregon, 1999 ............. 21

4. Location of temperature monitoring stations in the middle and upper Deschutes River Basin, Oregon .................. 26

5. Turbidity, total suspended solids, and sediment monitoring stations in the middle and upper

Deschutes River Basin, Oregon

6. Nutrient, dissolved oxygen, and $\mathrm{pH}$ monitoring stations in the middle and upper

Deschutes River Basin, Oregon

\section{TABLES}

1. Matrix showing proposed implementation schedule for suggested long-term monitoring actions in the middle and upper Deschutes River Basin, Oregon

2. Definition of reaches of the middle and upper Deschutes River Basin and selected tributaries, including estimated ground-water gains and losses and water-quality issues identified by the State of Oregon

3. Summary of relevant monitoring activities in the middle and upper Deschutes River Basin.

4. Historical and current fish and amphibian species in the waters of the middle and upper Deschutes River Basin .......... 13

5. Laboratory and field methods for sampling, preservation, and analysis of nutrients in water samples used by the Oregon Department of Environmental Quality in the Ambient Monitoring Program

6. Summary of objectives and suggested monitoring actions for coordinated, regional water-quality monitoring in the middle and upper Deschutes River Basin

\section{CONVERSION FACTORS}

\begin{tabular}{rll}
\hline Multiply & By & To obtain \\
\hline foot $(\mathrm{ft})$ & 0.3048 & meter $(\mathrm{m})$ \\
mile $(\mathrm{mi})$ & 1.609 & kilometer $(\mathrm{km})$ \\
cubic foot per second $\left(\mathrm{ft}^{3} / \mathrm{s}\right)$ & 0.02832 & cubic meter per second $\left(\mathrm{m}^{3} / \mathrm{s}\right)$ \\
feet per second $(\mathrm{ft} / \mathrm{s})$ & 0.3048 & meter per second $(\mathrm{m} / \mathrm{s})$ \\
milligrams per liter $(\mathrm{mg} / \mathrm{L})$ & 1 & parts per million $(\mathrm{ppm})$ \\
\hline
\end{tabular}

Temperature in degrees Celsius $\left({ }^{\circ} \mathrm{C}\right)$ may be converted to degrees Fahrenheit $\left({ }^{\circ} \mathrm{F}\right)$ as follows: ${ }^{\circ} \mathrm{F}=1.8\left(\right.$ temperature, in $\left.{ }^{\circ} \mathrm{C}\right)+32$

\section{MAP SOURCES:}

Base map modified from U.S. Geological Survey 1:500,000 State base map, 1982,

w ith digital data from U.S. Bureau of the Census, TIGER/Line (R), 1990, and

U.S. Geological Survey Digital Line Graphs published at 1:100,000.

Public ation projection is Lambert Conformal Conic.

Standard parallels $43^{\circ} 00^{\prime}$ and $45^{\circ} 30^{\prime}$, central meridian- $120^{\circ} 30^{\prime}$. 


\section{ACKN OW LEDGMENTS}

Funding for this cooperative project was provided to the Upper Deschutes Watershed Council by a grant from the Oregon Watershed Enhancement Board. A committee was convened on several occasions from 1998-2000 to help develop the plan for interagency monitoring in the upper Deschutes River Basin. This group was instrumental in identifying issues, providing information on previous and current monitoring programs, developing and agreeing on monitoring actions, and providing valuable reviews of the monitoring plan as it was written. The committee was organized and convened by Barbara Lee, Coordinator for the Upper Deschutes Watershed Council. Mollie Chaudet, Wild and Scenic Rivers Coordinator, and the Bend/Ft. Rock District of the Deschutes National Forest provided meeting space and logistics for committee meetings. Facilitation was provided by Gery Ferguson of the Deschutes National Forest. Bonnie Lamb, Oregon Department of Environmental Quality, spent many hours gathering information, creating Geographic Informatin Systems (GIS) coverages, and generating preliminary maps showing current monitoring programs and 303(d) listed segments for streamflow, temperature, sediment and turbidity, and nutrients. The Confederated Tribes of the Warm Springs Reservation also provided early input to this process. The following is a list of committee members.

\begin{tabular}{|c|c|}
\hline Name & Organization \\
\hline Bonnie Lamb & Oregon Department of Environmental Quality \\
\hline Steve Marx & Oregon Department of Fish and Wildlife \\
\hline Kyle Gorman & Oregon Water Resources Department \\
\hline Robert Main & Oregon Water Resources Department \\
\hline Barbara Lee & Upper Deschutes Watershed Council \\
\hline John Mason & Deschutes County \\
\hline Beverly Sunderlind & City of Bend \\
\hline Roger Prowell & City of Bend \\
\hline Scott Lewis & Portland General Electric \\
\hline Michelle McSwain & U.S. Bureau of Land Management \\
\hline Larry Zakrajsek & U.S. Bureau of Reclamation \\
\hline Jerry Cordova & U.S. Fish and Wildlife Service \\
\hline Mollie Chaudet & U.S. Forest Service, Bend/Ft. Rock Ranger District \\
\hline Tom Walker & U.S. Forest Service, Bend/Ft. Rock Ranger District \\
\hline Beth Sanchez & U.S. Forest Service, Crescent Ranger District \\
\hline Randy Gould & U.S. Forest Service, Deschutes Ranger District \\
\hline Mark Wilcox & U.S. Forest Service, Deschutes Ranger District \\
\hline Robert Rock & U.S. Forest Service, Ochoco Ranger District \\
\hline Jim Seymour & U.S. Forest Service, Ochoco Ranger District \\
\hline Richard Vacirca & U.S. Forest Service, Ochoco Ranger District \\
\hline Brad Houslet & U.S. Forest Service, Sisters Ranger District \\
\hline Mike Riehle & U.S. Forest Service, Sisters Ranger District \\
\hline Chauncey Anderson & U.S. Geological Survey \\
\hline
\end{tabular}




\title{
Framew ork for Regional, Coordinated M onitoring in the M iddle and Upper Deschutes River Basin, Oregon
}

\author{
By Chauncey W. Anderson
}

\subsection{Summary}

This report presents a framework for regional water-quality monitoring in the middle and upper Deschutes River Basin, Oregon, that would be coordinated among organizations doing related monitoring. The emphasis is on maximizing the value of existing programs and resources by minimizing overlapping sampling efforts, filling key data gaps, increasing communication about results, and facilitating coordination and cooperation among organizations. The report was developed in conjunction with the Upper Deschutes Watershed Council and a committee of representatives from each of the organizations listed in the Acknowledgments (hereafter referred to as the Upper Deschutes Water Quality Monitoring Committee, or "the Committee"). This group helped to (1) determine the water-quality issues to be addressed, (2) provide information on current programs in the basin, (3) develop the overall monitoring objectives, and (4) reach agreement on the general monitoring framework.

\subsection{Monitoring Goals}

The principal goals for this monitoring program are, in order of importance, to (1) understand the condition of a resource or changes in the status of critical parameters over time ("Status and Trends" monitoring), (2) determine whether conditions meet established criteria, reference levels, or standards ("Compliance monitoring"), and (3) assess the affects of land use or effectiveness of changes in resource management ("Evaluation monitoring"). For this plan, the primary goal is to provide data that can be used to evaluate the status and trends of waterquality related resources in the basin. Compliance monitoring needs will be met in part by data collected under this plan, but for some constituent groups or issues, such monitoring will require additional data collection targeted to answer specific questions. Evaluation monitoring will primarily be addressed through the use of short term, targeted studies with specific, narrowly defined objectives.

\subsection{Suggested Monitoring Plan}

The monitoring plan is organized by waterquality topic, with subsections addressing monitoring objectives and suggestions for monitoring actions to provide data for Status and Trends, Compliance, and (or) Evaluation monitoring. These objectives and actions were developed in conjunction with the Upper Deschutes Water Quality Monitoring Committee. The plan also suggests ways to increase the efficiency and usefulness of data collected to date, which in many cases have not been analyzed or communicated. Some suggested monitoring actions would provide data necessary for other actions to be carried out, whereas others would likely require data from a previous action in order to be completed. Other monitoring actions, especially special studies to answer questions about specific land-use or water-management practices, could be most effectively addressed by pooling of efforts among organizations, due to expense or limited resources within individual organizations. Some agencies might be unable to make major changes in their monitoring programs without internal deliberations, and possibly until new funding cycles are completed.

One way to account for the above considerations would be to implement the monitoring program in phases (table 1). Each phase would build upon the previous one, although some programs, especially the larger special studies, might extend into the next phase. The timing of the phases may correspond to funding cycles or possibly to time frames set by the agencies in conjunction with upcoming programs. 
Table 1. Matrix showing proposed implementation schedule for suggested long-term monitoring actions in the [Numbers correspond to the order the actions are presented in the text; EPA, Environmental Protection Agency; ODEQ, Oregon Department of DO, dissolved oxygen]

\begin{tabular}{|c|c|c|c|c|c|}
\hline $\begin{array}{c}\text { Phase of } \\
\text { implementation }\end{array}$ & $\begin{array}{l}\text { Monitoring } \\
\text { coordination and } \\
\text { management }\end{array}$ & Discharge & Water temperature & $\begin{array}{l}\text { Turbidity/sediment } \\
\text { transport }\end{array}$ & $\begin{array}{c}\text { Channel morphology } \\
\text { and habitat }\end{array}$ \\
\hline Phase 1 & $\begin{array}{l}\text { (1) Establish coordinat- } \\
\text { ing mechanism } \\
\text { (3) Establish common } \\
\text { protocols } \\
\text { (4) Develop quality- } \\
\text { assurance plans } \\
\text { (5) Establish data man- } \\
\text { agement strategy } \\
\text { (7) Analyze and commu- } \\
\text { nicate existing infor- } \\
\text { mation }\end{array}$ & $\begin{array}{l}\text { (9) Continue current net- } \\
\text { work }\end{array}$ & $\begin{array}{l}\text { (12) Compile existing } \\
\text { data and evaluate } \\
\text { QA/QC data }\end{array}$ & $\begin{array}{l}\text { (19) Compile existing } \\
\text { data and evaluate } \\
\text { QA/QC data }\end{array}$ & $\begin{array}{l}\text { (25) Compile existing } \\
\text { data and evaluate } \\
\text { metadata }\end{array}$ \\
\hline Phase 2 & $\begin{array}{l}\text { (1) Continue oversight, } \\
\text { and implement Phase 2 } \\
\text { monitoring compo- } \\
\text { nents } \\
\text { (2) Conduct periodic } \\
\text { reviews of monitoring } \\
\text { program } \\
\text { (7) Continue to analyze } \\
\text { and communicate } \\
\text { existing information }\end{array}$ & $\begin{array}{l}\text { (8) Update streamflow } \\
\text { records and publish } \\
\text { data } \\
\text { (10) Work with ODEQ } \\
\text { to collocate stream- } \\
\text { gaging and water- } \\
\text { quality stations }\end{array}$ & $\begin{array}{l}\text { (13) Analyze existing } \\
\text { data } \\
\text { (14) Use continuous } \\
\text { monitors in place of } \\
\text { grab samples where } \\
\text { possible, and time grab } \\
\text { sampling to account } \\
\text { for diel variations } \\
\text { (15) Begin to remove } \\
\text { redundant stations and } \\
\text { add new stations to fill } \\
\text { data gaps }\end{array}$ & $\begin{array}{l}\text { (18) Promote TSS as } \\
\text { preferred sampling } \\
\text { protocol } \\
\text { (20) Analyze existing } \\
\text { data } \\
\text { (21) Establish new sta- } \\
\text { tions below Wickiup } \\
\text { Reservoir and near La } \\
\text { Pine } \\
\text { (22) Begin continuous } \\
\text { turbidity monitoring } \\
\text { at selected locations } \\
\text { (especially down- } \\
\text { stream of Wickiup } \\
\text { Reservoir) } \\
\text { (23) Study relations } \\
\text { between sediment } \\
\text { concentrations, TSS, } \\
\text { and turbidity }\end{array}$ & $\begin{array}{l}\text { (26) Analyze existing } \\
\text { data } \\
\text { (27) Begin monitoring at } \\
\text { subbasin and indicator } \\
\text { reach scales } \\
\text { (28) Consider studies to } \\
\text { establish baselines for } \\
\text { critical reaches not yet } \\
\text { surveyed } \\
\text { (29) Consider studies to } \\
\text { evaluate changes in } \\
\text { channel geometry } \\
\text { below reservoirs rela- } \\
\text { tive to historical condi- } \\
\text { tions }\end{array}$ \\
\hline Phase 3 & $\begin{array}{l}\text { (1) Continue oversight, } \\
\text { implement Phase } 2 \\
\text { monitoring compo- } \\
\text { nents, and conduct } \\
\text { periodic reviews as } \\
\text { warranted }\end{array}$ & $\begin{array}{l}\text { (11) Develop models to } \\
\text { increase predictability } \\
\text { of snowmelt and } \\
\text { ground water to reser- } \\
\text { voirs and key river } \\
\text { reaches }\end{array}$ & $\begin{array}{l}\text { (16) Develop tempera- } \\
\text { ture model for 303(d) } \\
\text { listed reaches for } \\
\text { TMDL development } \\
\text { and to investigate } \\
\text { effects of resource- } \\
\text { management scenarios } \\
\text { (17) Consider studies to } \\
\text { determine effects on } \\
\text { temperature from dif- } \\
\text { ferent resource- } \\
\text { management scenarios }\end{array}$ & $\begin{array}{l}\text { (24) Consider study to } \\
\text { determine relations } \\
\text { between bedload trans- } \\
\text { port and flow changes, } \\
\text { and determine sedi- } \\
\text { ment sources below } \\
\text { Wickiup Reservoir }\end{array}$ & $\begin{array}{l}\text { (30) Consider studies in } \\
\text { selected reaches to } \\
\text { evaluate effects of } \\
\text { changes in flow on } \\
\text { stream physical envi- } \\
\text { ronments, water qual- } \\
\text { ity, and stream ecology }\end{array}$ \\
\hline Phase 4 & $\begin{array}{l}\text { (1) Continue oversight, } \\
\text { implement Phase } 2 \\
\text { monitoring compo- } \\
\text { nents, and conduct } \\
\text { periodic reviews as } \\
\text { warranted }\end{array}$ & & & & \\
\hline
\end{tabular}




\begin{tabular}{|c|c|c|c|c|c|}
\hline Nutrients & $\begin{array}{c}\text { Dissolved oxygen } \\
\text { and pH }\end{array}$ & Bacteria & $\begin{array}{l}\text { Nonindigenous } \\
\text { species }\end{array}$ & Macroinvertebrates & Toxic constituents \\
\hline \begin{tabular}{|l} 
(31) Compile existing \\
data and evaluate QA/ \\
QC data \\
(35) Follow EPA process \\
to develop nutrient cri- \\
teria for rivers and \\
lakes
\end{tabular} & $\begin{array}{l}\text { (38) Compile existing } \\
\text { data and evaluate QA/ } \\
\text { QC data }\end{array}$ & $\begin{array}{l}\text { (43) Compile existing } \\
\text { data and evaluate QA/ } \\
\text { QC data }\end{array}$ & & $\begin{array}{l}\text { (51) Compile existing } \\
\text { data and evaluate } \\
\text { metadata }\end{array}$ & \\
\hline \begin{tabular}{|l|} 
(32) Analyze existing \\
data \\
(33) Promote use of \\
ODEQ field and labora- \\
tory protocols as pre- \\
ferred methods among \\
monitoring agencies
\end{tabular} & $\begin{array}{l}\text { (39) Analyze existing } \\
\text { data } \\
\text { (40) Establish continu- } \\
\text { ous monitors for DO, } \\
\text { pH, specific conduc- } \\
\text { tance, and turbidity, at } \\
\text { selected ODEQ ambi- } \\
\text { ent monitoring or } \\
\text { ODFW stream-gaging } \\
\text { locations } \\
\text { (41) Modify field proto- } \\
\text { cols for grab samples } \\
\text { to sample at times that } \\
\text { will best document } \\
\text { diel extremes in DO } \\
\text { and pH. }\end{array}$ & & \begin{tabular}{|c|} 
(48) Establish contact \\
person in basin for \\
Aquatic Nuisance \\
Species (ANS) \\
(47) Participate in \\
statewide plan for \\
control of ANS, and \\
develop list of inva- \\
sive aquatic species \\
of concern, in con- \\
junction with West- \\
ern Regional Panel \\
of Aquatic Nuisance \\
Species Task Force
\end{tabular} & \begin{tabular}{|} 
(52) Use existing data \\
to assess current con- \\
ditions in macroin- \\
vertebrate \\
assemblages and \\
indicated water and \\
habitat quality
\end{tabular} & $\begin{array}{l}\text { (54) Assemble infor- } \\
\text { mation on permitted } \\
\text { point-source dis- } \\
\text { charges to rivers and } \\
\text { existing data on toxic } \\
\text { compounds in water, } \\
\text { sediments, or aquatic } \\
\text { biota } \\
\text { (55) Compile existing } \\
\text { environmental data } \\
\text { on toxics and evalu- } \\
\text { ate QA/QC data } \\
\text { (57) Change protocols } \\
\text { used for sampling } \\
\text { mercury to use fish } \\
\text { tissues and sediment } \\
\text { rather than water as } \\
\text { sampling media }\end{array}$ \\
\hline \begin{tabular}{|l|} 
(34) Increase frequency \\
of sampling in Wick- \\
iup Reservoir and Cres- \\
cent Lake \\
(36) Consider studies to \\
evaluate various nutri- \\
ent and eutrophication \\
issues in basin (pro- \\
vides support to \\
TMDLs)
\end{tabular} & $\begin{array}{l}\text { (42) Consider special } \\
\text { studies to evaluate var- } \\
\text { ious } \mathrm{DO} / \mathrm{pH} \text { and } \\
\text { eutrophication issues } \\
\text { in basin (provides sup- } \\
\text { port to TMDLs) }\end{array}$ & $\begin{array}{l}\text { (44) Analyze existing } \\
\text { data } \\
\text { (45) Maintain current } \\
\text { ODEQ sampling net- } \\
\text { work, and add stations } \\
\text { as indicated by analy- } \\
\text { sis of existing data or } \\
\text { special studies }\end{array}$ & $\begin{array}{l}\text { (49) Conduct cam- } \\
\text { paigns to educate } \\
\text { the public about } \\
\text { invasive species }\end{array}$ & $\begin{array}{l}\text { (53) Use information } \\
\text { from analysis of } \\
\text { existing data to refine } \\
\text { future monitoring for } \\
\text { macroinvertebrates, } \\
\text { water quality, and } \\
\text { habitat, if warranted }\end{array}$ & $\begin{array}{l}\text { (56) Conduct recon- } \\
\text { naissance samplings } \\
\text { for trace metals in } \\
\text { water and in sedi- } \\
\text { ments, dissolved pes- } \\
\text { ticides in water, and/ } \\
\text { or polycyclic aro- } \\
\text { matic hydrocarbons } \\
\text { (PAHs) in water and } \\
\text { sediments }\end{array}$ \\
\hline \begin{tabular}{|l|} 
(37) Consider study to \\
determine historical \\
water quality in lakes \\
and reservoirs, and pos- \\
sible downstream water \\
quality, by using lake- \\
sediment geochemistry \\
and diatom records
\end{tabular} & & $\begin{array}{l}\text { (46) Consider special } \\
\text { studies to determine } \\
\text { degree of bacterial } \\
\text { problems at popular } \\
\text { recreational areas }\end{array}$ & \begin{tabular}{|l|} 
(50) Conduct peri- \\
odic surveys to esti- \\
mate coverage or \\
populations of inva- \\
sive species
\end{tabular} & & $\begin{array}{l}\text { (58) Communicate } \\
\text { results of reconnais- } \\
\text { sance samplings } \\
\text { (59) Decide on need } \\
\text { for additional moni- } \\
\text { toring or special } \\
\text { studies based on } \\
\text { reconnaissance study } \\
\text { results }\end{array}$ \\
\hline
\end{tabular}


Descriptions of the proposed phases are as follows:

Phase 1 would focus primarily on program management and implementation, including the creation of institutional agreements. It might involve actions to be done principally within the auspices of the individual organizations and with existing resources. No changes to current monitoring programs would be made, but compilation of datasets among agencies and analysis of quality assurance data in preparation for data analysis in Phase 2 could be initiated.

Phase 2 would include minor modifications to existing monitoring programs and the analysis of data compiled in the previous phase. Other actions, upon which future monitoring will depend, would be initiated. Critical special studies to fill data gaps, or to provide data in support of important programs (such as allocation of Total Maximum Daily Loads [TMDLs]), would also be initiated.

Phase 3 would mark the beginning of more substantial modifications to existing programs, such as addition or relocation of monitoring sites. It would also include special studies to evaluate important land use or resource management issues. By the end of this phase much of the monitoring plan would have been implemented.

Phase 4 would include the largest changes to existing programs, along with actions on issues deemed less important regionally or that would be relatively expensive to evaluate.

The final decisions on phasing of monitoring actions, the order of implementation or priority, and the responsibilities of individual organizations, are beyond the scope of this report. Furthermore, the implementations of items in each phase could change as the plan is reevaluated periodically and local issues change in importance. This is particularly true for the later phases because the results from earlier phases could cause shifts in the understanding and priority of different issues

\subsection{Introduction}

The Deschutes River Basin, in central Oregon (fig.1), is an area known for its spectacular beauty. The terrain ranges from high mountains to deep river valleys, and the climate is dry and relatively mild. The combination of climate, abundant recreational opportunities, and outstanding natural resources, has resulted in increasing population growth, which in turn has increased pressures on those natural resources. Chief among these is water: Most of the surface water in the basin has been allocated; there are numerous threatened or endangered aquatic species, including salmonid fishes; and water use, land managment, and development have affected the hydrology, water-quality, channel configuration, and aquatic and riparian habitats in most major streams or rivers.

Natural-resource management agencies in the basin confronted with these problems are charged with balancing the needs of the resources with the needs of the growing human population, often in the face of shrinking budgets. Monitoring of water quantity and quality is one of the tools used by agencies to assess the effects of management decisions on resources and to make decisions about future land uses in the basin. Yet many natural resource agencies have overlapping or sometimes contradictory geographical and topical areas of interest, responsibility, and (or) missions. In the absence of a coordinated strategy and long-term, open communication between agencies, individual agency monitoring programs may be redundant, leave important data gaps, provide incomparable data because of differences in objectives and methods, provide data that are not used because of lack of awareness, or have other inefficiencies.

\subsection{Purpose and Scope}

This report presents a framework for coordinated, integrated, long-term monitoring by local, State, Tribal, and Federal agencies in the middle and upper Deschutes River Basin and selected tributaries. It includes a review of current, ongoing monitoring activities, suggestions for monitoring actions to be done on a regular basis or as special studies to fill important data gaps, and suggestions for reducing redundancies between agencies. There are also suggestions for establishing a mechanism to ensure the continued, coordinated implementation of this plan and 


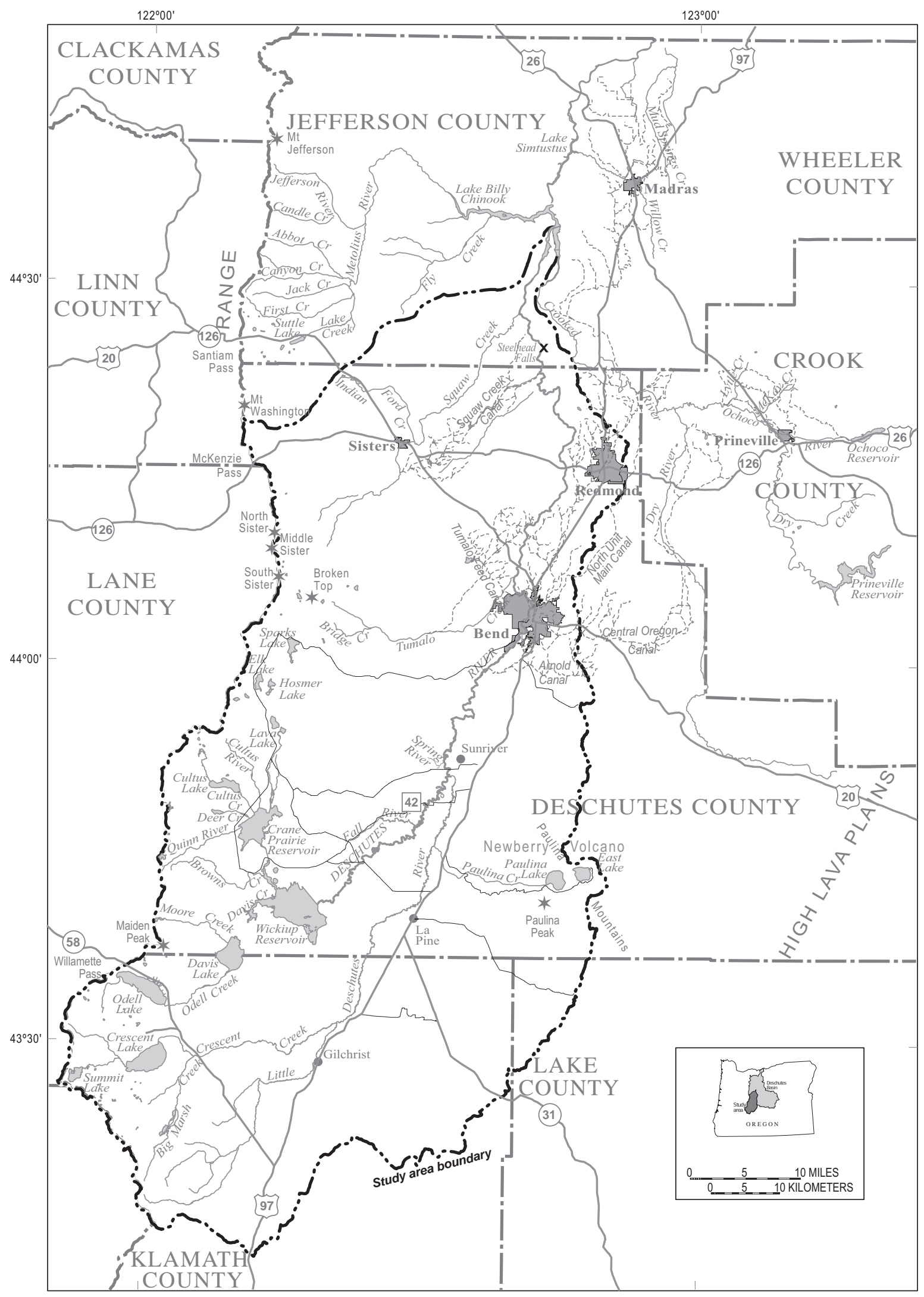

Figure 1. Middle and upper Deschutes River Basin, Oregon. 
to reevaluate the plan after a period of time following implementation. These suggestions were developed in conjunction with the Upper Deschutes Water Quality Monitoring Committee. A summary of objectives and suggested monitoring actions for each monitoring topic is provided at the beginning of each topical section, with subsequent explanation of individual actions. A glossary (p. 83) provides definitions of terms and acronyms used in this report.

For this plan, the primary goal is to provide data that can be used, at a regional level, to determine the status and trends of water-quality related resources in the basin. Compliance monitoring needs will be met in part by data collected under this plan, but for some constituent groups or issues additional data collection, targeted to answer specific questions, will likely be required. Evaluation of resource-management changes or land-use practices will typically be most effectively addressed through the use of short-term, targeted studies that have specific, narrowly defined objectives.

A first step in meeting the plan's goals is to make more effective use of existing data-collection programs through inventory, compilation review, assessment, and communication of those data, tasks that are generally beyond the scope of this document. Modifications to ongoing sampling programs are generally considered to be a second step, because in most cases decisions on changes to base programs will be most effective if they are founded on analysis of existing data. Furthermore, increasing or decreasing the number of monitoring locations, the frequency of sampling, or the number of constituents sampled will, in all likelihood, require changes in priorities of resource allocation or funding levels for most organizations. These types of changes will take time to implement because they often require, at best, a full funding cycle for most public agencies, in addition to decision making at various levels within those agencies and agreements among multiple organizations. In some cases reconnaissance data collection or other special studies are suggested as interim steps in order to provide data needed to make further monitoring decisions.
No attempt has been made to place priorities on the individual monitoring actions, in part because the priorities will vary by organization. However, a possible approach using a phased implementation of the monitoring program is outlined in the Summary section and in table 1. The phases described are not based on priorities of issues or monitoring actions, but rather on a sequence of logical steps that might be used to create a coordinated, regional program without causing rapid, undue disruption to current programs.

The monitoring plan does not, and cannot, accommodate all aspects of data collection and management in the study area. Many of the priorities, responsibilities, and data requirements of the individual land- and water-management agencies are unique to those agencies and are properly carried out within their own programs. Rather, the monitoring plan is intended to provide a base-level structure to supply data at a regional level, for use or augmentation by any organizations or researchers for a variety of purposes. The data collected might not be sufficient to answer all questions about the effect of management actions, or the combined effect of multiple management actions, on water quality. It would, however, provide indications of changing conditions over time, allowing additional investigations to be done to determine causes or define the extent of those changes.

Funding is an obvious constraint for most organizations. This plan does not take costs into account in providing a framework for coordinated monitoring. By working with this plan, and agreeing to strive for enhanced coordination in water-related monitoring in the study area, organizations are not necessarily expected to expend their finite resources except of their own volition. It will be the task of the combined organizations involved in coordinated monitoring to agree on a funding strategy for monitoring to supplement current programs.

\subsection{Study Area}

The water bodies under consideration for this monitoring plan (fig. 1) include the Deschutes River upstream of Lake Billy Chinook to Wickiup Reservoir and its major tributaries (Little 
Deschutes River from the mouth to the headwaters and to Crescent Lake, Squaw Creek, Tumalo Creek, and Paulina Creek). Some additional tributaries such as Fall River and Spring River are included where there are existing data collection activities and those activities contribute to the supply of data for the upper Deschutes River; however, the monitoring plan does not address these smaller systems explicitly. For selected topics, additional considerations are given to the Wickiup and Crane Prairie Reservoirs themselves, areas and tributaries upstream of the reservoirs, and the extensive irrigation canal system. The Crooked River and Metolius River systems are excluded from this monitoring plan in order to keep the tasks of assessing current monitoring, and designing future monitoring, to a manageable level. However, this plan could provide a basis for additional integrated monitoring in those basins if there is sufficient interest.

The study area includes several urban areas, most notably the communities of Bend, Redmond, Sisters, and La Pine, within Deschutes, Jefferson, and Klamath Counties. The headwaters of most of the area's streams predominantly drain forested and mountainous terrain, with the lowlands being composed of broad, high lava plains containing a mixture of land uses including irrigated agriculture, livestock pastureland and dairies, urban/ residential/industrial land, and recreational areas associated with the region's abundant natural resources. A generalized description of regional geology and hydrogeologic flow patterns is given by Caldwell (1998).

For the purposes of stratification and to focus monitoring resources, the study area was divided into 10 major stream reaches (table 2; fig. 2) according to flow volumes and independent geographic areas. This division is the same as that used by the Oregon Department of Environmental Quality for listing stream reaches as water-quality limited according to the Clean Water Act. Some of the reaches have been divided into subreaches for management purposes by individual agencies (for example, see U.S. Department of Agriculture Forest Service, 1996, for subreaches of the upper Deschutes River) but this monitoring plan is primarily targeted at a more regional scale. Hereinafter, the term "upper Deschutes River Basin" refers to the entire watershed upstream of
Bend (that is, reaches $2-5$ and 10 in table 2 and figure 2). The reach between the dam at Wickiup Reservoir and the mouth of the Little Deschutes River is sometimes referred to herein as the "upper Deschutes River below Wickiup Reservoir." The "middle Deschutes River" refers to the reach from the North Unit Main Canal to Lake Billy Chinook (reaches 6 and 8) and associated tributaries.

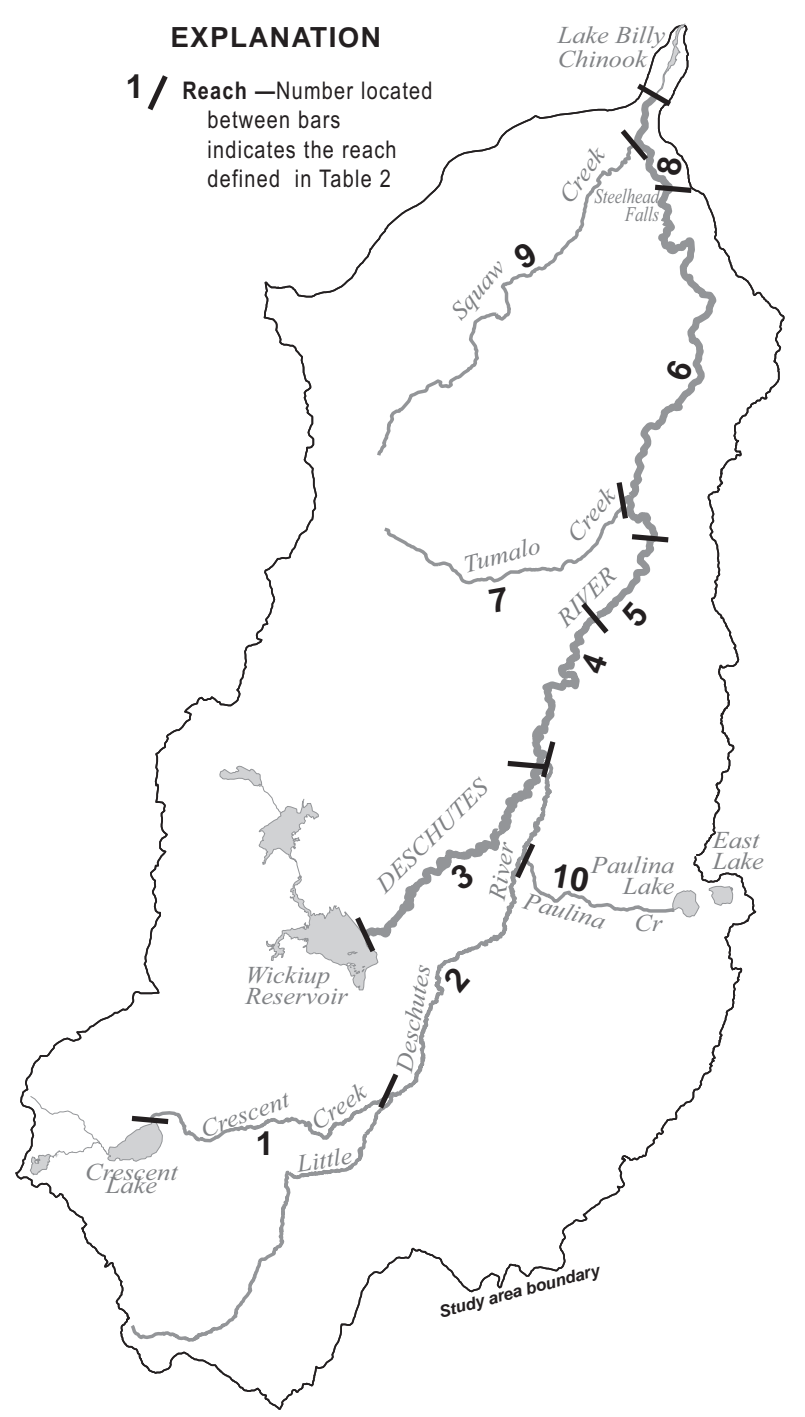

Figure 2. Designated reaches for regional monitoring in the upper and middle Deschutes River Basin, Oregon.

Several of the study reaches or subreaches have special management designations, and as such have been the subject of specific management plans (U.S. Department of Agriculture, Forest Service, 1996a; U.S. Department of the Interior, Bureau of Land Management and U.S. Department 
Table 2. Definition of reaches of the Upper Deschutes River Basin and selected tributaries, including estimated ground-water gains

and losses and water-quality issues identified by the State of Oregon

[Reaches are indicated in figure 2. Data on status of reach ground-water inputs or losses from Gannett and others (in press); Data on Water Quality issues from Oregon Department of Environmental Quality; "303(d) list"- reach is designated water-quality limited by the State under the Clean Water Act; "needs data"- there are indications that the reach could

be designated as water-quality limited by the State but insufficient data exist to make a final designation; COID Central Oregon Irrigation Diversion]

\begin{tabular}{|c|c|c|c|c|}
\hline $\begin{array}{c}\text { Reach } \\
\text { number }\end{array}$ & Monitoring reach & River miles & $\begin{array}{l}\text { Flow status } \\
\text { (fluctuating, gaining, } \\
\text { losing, or stable reach) }\end{array}$ & Water-quality issues \\
\hline 1 & $\begin{array}{l}\text { Crescent Creek, from Crescent Lake to mouth (Little } \\
\text { Deschutes river mile 57.3) }\end{array}$ & $30.0-0$ & Gaining & $\begin{array}{l}\text { Temperature—303(d) list } \\
\text { Flow modification—needs data }\end{array}$ \\
\hline 2 & $\begin{array}{l}\text { Little Deschutes River, from headwaters to mouth } \\
\text { (Upper Deschutes river mile 192.5) }\end{array}$ & $63.3-0$ & Slightly Gaining & $\begin{array}{l}\text { Temperature—303(d) list (mouth to Hemlock Creek) } \\
\text { Bacteria—needs data (mouth to Crescent Creek) } \\
\text { Flow modification—-needs data } \\
\text { Habitat modification—-needs data } \\
\text { Nutrients—needs data } \\
\text { Sedimentation—needs data }\end{array}$ \\
\hline 3 & $\begin{array}{l}\text { Upper Deschutes River, from Wickiup Reservoir to } \\
\text { Little Deschutes River }\end{array}$ & $226.8-192.5$ & Stable & $\begin{array}{l}\text { Dissolved Oxygen-303(d) list } \\
\text { Flow modification-303(d) list } \\
\text { Habitat modification-303(d) list } \\
\text { Sedimentation-303(d) list } \\
\text { Turbidity-303(d) list }\end{array}$ \\
\hline 4 & $\begin{array}{l}\text { Upper Deschutes River, from Little Deschutes to } \\
\text { COID }\end{array}$ & $192.5-169.9$ & $\begin{array}{l}\text { Gaining (to Harper's Bridge), } \\
\text { Losing (Harper's Bridge to } \\
\text { COID) }\end{array}$ & $\begin{array}{l}\text { Dissolved Oxygen-303(d) list (Little Deschutes to COID) } \\
\text { Habitat modification-303(d) list } \\
\text { Sedimentation-303(d) list } \\
\text { Turbidity_303(d) list } \\
\text { pH-303(d) list }\end{array}$ \\
\hline 5 & $\begin{array}{l}\text { Upper Deschutes River, from COID to North Unit } \\
\text { Main Canal }\end{array}$ & $169.9-164.8$ & Losing & $\begin{array}{l}\mathrm{pH}-303(\mathrm{~d}) \text { list } \\
\text { Flow modification—303(d) list (COID to North Unit Canal) } \\
\text { Habitat modification—-needs data } \\
\text { Sedimentation—needs data } \\
\text { Turbidity—needs data } \\
\text { Nutrients—needs data }\end{array}$ \\
\hline 6 & $\begin{array}{l}\text { Middle Deschutes River, from North Unit Main Canal } \\
\text { to Steelhead Falls }\end{array}$ & $164.8-127.8$ & Steady & $\begin{array}{l}\text { Flow modification-303(d) list } \\
\text { pH-303(d) list } \\
\text { Sedimentation-needs data } \\
\text { Temperature-303(d) list }\end{array}$ \\
\hline 7 & $\begin{array}{l}\text { Tumalo Creek, from Headwaters to mouth (Middle } \\
\text { Deschutes river mile 160.2) }\end{array}$ & All & Gaining & $\begin{array}{l}\text { Flow modification-303(d) list (mouth to Columbia Southern Canal) } \\
\text { Habitat modification—needs data (mouth to Columbia Southern Canal) }\end{array}$ \\
\hline 8 & $\begin{array}{l}\text { Middle Deschutes River, from Steelhead Falls to Lake } \\
\text { Billy Chinook }\end{array}$ & $127.8-120.0$ & Gaining & $\begin{array}{l}\text { Flow modification—needs data } \\
\text { pH—303(d) list } \\
\text { Sedimentation—needs data }\end{array}$ \\
\hline 9 & $\begin{array}{l}\text { Squaw Creek, from headwaters to mouth (Deschutes } \\
\text { river mile 123.1) }\end{array}$ & All & $\begin{array}{l}\text { Stable (to Alder Springs), } \\
\text { Gaining (Alder Springs to } \\
\text { mouth) }\end{array}$ & $\begin{array}{l}\text { Flow modification-303(d) list (Alder Springs to Maxwell Ditch) } \\
\text { Habitat modification—-needs data (Alder Springs to Maxwell Ditch) } \\
\text { Temperature—303(d) list (Alder Springs to Maxwell Ditch) }\end{array}$ \\
\hline 10 & Paulina Creek from Paulina Lake to mouth & All & Losing & Temperature-303(d) list \\
\hline
\end{tabular}


of Agriculture, Forest Service, 1992). The upper

Deschutes River, from Wickiup Reservoir to upstream of the Central Oregon Irrigation District (COID) canal on the southern side of Bend (reach 3 and part of reach 4), is designated as Federal Wild and Scenic, and several segments are also designated as a State Scenic Waterway (U.S. Department of Agriculture, Forest Service, 1996a). The middle Deschutes River has four subreaches designated as State Scenic Waterways, either solely or in combination with Federal Wild and Scenic designation (U.S. Department of Agriculture, Forest Service, 1996a). A portion of Squaw Creek (reach 9) also is designated as Federal Wild and Scenic, with a management plan pending (U.S. Department of Agriculture, Forest Service, 1998).

\subsection{Water Management in the Upper Deschutes Basin}

Many agencies are involved in the various aspects of water management in the middle and upper Deschutes River Basin, including the Oregon Water Resources Department (OWRD); the Oregon Department of Environmental Quality (ODEQ); the Oregon Department of Fish and Wildlife (ODFW); the Oregon State Parks and Recreation Department; Deschutes, Jefferson, and Klamath Counties; the cities of Bend, Redmond, and Sisters; the U.S. Forest Service (USFS) through the Bend/Fort Rock, Crescent, and Sisters Ranger Districts of the Deschutes National Forest; the Prineville office of the Bureau of Land Management (BLM); the U.S. Fish and Wildlife Service (USFWS); The U.S. Bureau of Reclamation (BOR); the Confederated Tribes of the Warm Springs Reservation; and several local irrigation districts. A private entity, Portland General Electric (PGE), which operates the hydroelectric facility at Lake Billy Chinook, also collects data in the basin, and management of the lake could become an issue farther upstream because water-quality standards for temperature, dissolved oxygen, and $\mathrm{pH}$ are sometimes violated during summer in the lake (E\&S Environmental Chemistry, 1997).

\subsection{Water-Quality Issues}

Representatives of the agencies participating in the development of this monitoring plan identified the principal issues to be addressed after review of known issues (table 2), recommendations from existing plans (Appendix A, table A-1), and their own agency programs (table 3 ) and overall priorities (Appendix A). The primary issues related to or indicative of water quality in the basin are water quantity (and its temporal pattern), stream temperature, turbidity and sediment transport, eutrophication (effects of nutrient and other inputs on dissolved oxygen, $\mathrm{pH}$, and indicator bacteria), macroinvertebrates, and physical status of channel configuration and habitat for aquatic biota. Flooding is not generally a problem for most of the study reaches because of flow regulation from reservoirs, irrigation withdrawals, and the overall stable flows resulting from ground water inputs to the system. However, some runoff is likely during snowmelt or rainstorms, and the smaller streams may swell at times. These events, which can be critical for transport of contaminants, are typically not monitored for water quality.

Table 2 indicates reaches included either on the State of Oregon's 303(d) list of waterquality limited streams (Oregon Department of Environmental Quality, 1999a), or its decision matrix for possible 303(d) listing where limited data exist. TMDLs will eventually be required for issues that are formally included on the 303(d) list by the State (Oregon Department of Environmental Quality, 1999a) and are planned for completion by the end of 2002 for the upper and Little Deschutes River Basin. There are 95 permit holders for pollution discharges within the study area, of which only 5 are National Point-Discharge Elimination System (NPDES) permits for direct or indirect discharge to the upper Deschutes River. The remainder are Water Pollution Control Facility (WPCF) or other general permits for domestic or industrial discharges of effluent to ground water or land (Oregon Department of Environmental Quality, 1999b). Nonpoint-source impacts qualitatively identified in a 1988 report by the State (Oregon 
Table 3. Summary of relevant monitoring activities in the Upper Deschutes River Basin

[D.R., Deschutes River; L.D.R., Little Deschutes River; C.R., Crooked River; Field, field parameter, including temperature, DO, pH, Specific Conductance; Alk, alkalinity; TSS, Total Suspended Solids (evaporated); TDS, Total Dissolved Solids; SS, Suspended Sediment; Nut., Nutrients; Majors, major ions (cations +anions); Bac-T, Bacteria; Benth, benthic invertebrates in wadeable streams; BOD, biological oxygen demand; COD, chemical oxygen demand; CBOD, carbonaceous biological oxygen demand; TOC, Total Organic Carbon; Alk, alkalinity; Note: TSS, TDS, and SS are indicated separately because of methods differences]

\begin{tabular}{|c|c|c|c|c|c|c|}
\hline \multirow{2}{*}{ Issue } & \multirow{2}{*}{ Monitoring program objectives } & \multicolumn{2}{|c|}{ Time frame } & \multirow{2}{*}{$\begin{array}{l}\text { Spatial coverage in upper } \\
\text { Deschutes River Basin }\end{array}$} & \multirow{2}{*}{ Constituents } & \multirow{2}{*}{ Remarks } \\
\hline & & Period & Frequency & & & \\
\hline \multicolumn{7}{|c|}{ Oregon Water Resources Department (OWRD)—Contact: Kyle Gorman 541-388-6669 } \\
\hline $\begin{array}{l}\text { Flow volume } \\
\text { (esp. at low flow) }\end{array}$ & - Data for allocation of water rights & Ongoing & every $15 \mathrm{~min}$ & $\begin{array}{l}\text { Approximately } 31 \text { sites in Upper Des- } \\
\text { chutes River Basin }\end{array}$ & -Streamflow & $\begin{array}{l}\text { Raw data available; } \\
\text { completed records } \\
\text { from 1992-present } \\
\text { not yet released }\end{array}$ \\
\hline - Temperature & -Stream temperatures & Ongoing & every $15 \mathrm{~min}$ & Various & -Temperature & $\begin{array}{l}\text { •Periodically checked, } \\
\text { not corrected }\end{array}$ \\
\hline \multicolumn{7}{|c|}{ Oregon Department of Environmental Quality (ODEQ)—Contact: Bonnie Lamb 541-388-6146 x239 } \\
\hline $\begin{array}{l}\text {-Ambient Water } \\
\text { Quality Monitoring }\end{array}$ & -Trend monitoring, Compliance & $\begin{array}{l}\text { Ongoing } \\
\text { (varies) }\end{array}$ & Bi-monthly & $\begin{array}{l}\text { •5 sites: Desch. Riv. @ Pringle Falls; } \\
\text { L.Desch. Riv. @ Hwy 42; } \\
\text { Desch. Riv. @ Harper Br. (Sunriver); } \\
\text { Desch. Riv. @ Mirror Pond; } \\
\text { Desch. Riv. @ Lower Br }\end{array}$ & $\begin{array}{l}\text {-Field, TSS, Alk, Bac-T, } \\
\text { Major ions, BOD, COD, } \\
\text { chlorophyll, TOC, color, } \\
\text { turbidity, }\end{array}$ & $\begin{array}{l}\text { No toxics regularly } \\
\text { monitored. See 305(b) } \\
\text { and 303(d) reports. } \\
\text { Data supports Water } \\
\text { Quality Index. }\end{array}$ \\
\hline $\begin{array}{l}\text {-Upper Deschutes } \\
\text { Water Quality Survey }\end{array}$ & $\begin{array}{l}\text { Reconnaissance/Evaluation of impacts } \\
\text { from development, temperature } \\
\text { problems, water withdrawals }\end{array}$ & $\begin{array}{l}\text {-1995-96 } \\
\quad \text { (one time study) }\end{array}$ & $\begin{array}{l}\cdot 2-4 \text { visits per } \\
\text { site, some } \\
\text { continuous }\end{array}$ & $\begin{array}{l}\text { •23 sites, mostly on Deschutes R., Little } \\
\text { Deschutes R., Crescent Cr., Fall R., } \\
\text { Squaw Cr. }\end{array}$ & $\begin{array}{l}\text {-Water chemistry, } \\
\text { temperature, other? }\end{array}$ & $\begin{array}{l}\text {-Data available but not } \\
\text { yet analyzed }\end{array}$ \\
\hline •REMAP & -Status and Trends & $\begin{array}{l}\cdot 1997-98 \\
\quad \text { (one time study) }\end{array}$ & $\begin{array}{l}\cdot 1 \text { visit per } \\
\text { site, plus } \\
\text { continuous } \\
\text { temperature }\end{array}$ & $\begin{array}{l}\cdot 15 \text { sites, plus some in Crooked \& } \\
\text { Metolius. Sites were randomly selected. }\end{array}$ & $\begin{array}{l}\text {-Water chemistry, } \\
\text { continuous temperature, } \\
\text { biological (inverts?), } \\
\text { riparian habitat }\end{array}$ & $\begin{array}{l}\text {-Water chemistry data } \\
\text { available, biological } \\
\text { and habitat data not } \\
\text { yet released }\end{array}$ \\
\hline \multicolumn{7}{|c|}{ US Environmental Protection Agency_Contact: Scott Augustine, Region 10 (Seattle) 206 553-1795 } \\
\hline - Temperature & -Analysis of QA for existing network & $\cdot$ & $\cdot \mathrm{NA}$ & -All known sites & -Water temperature & $\begin{array}{l}\text {-Work done by Stuart } \\
\text { Mckenzie, } \\
\text { USGS-retired }\end{array}$ \\
\hline \multicolumn{7}{|c|}{ City of Bend-Contact: Roger Prowell, 541-317-3017 } \\
\hline \multirow[t]{3}{*}{-Drinking water quality } & -Compliance & -Many Years & $\cdot$ Continous & -Bridge Creek above Tumalo Creek & -Turbidity, temperature & -Some data online \\
\hline & & •1990-present & $16-40 \mathrm{x} / \mathrm{mo}$ & •Bridge Creek above Tumalo Falls & $\begin{array}{l}\cdot \text { Fecal coliform, } \\
\text { inorganics / organics }\end{array}$ & $\begin{array}{l}\text { •low bact. counts, No } \\
\text { synthetic compds, all } \\
\text { inorganics }<\text { MCLs }\end{array}$ \\
\hline & & •Many Years & $\cdot$ Continous & Bridge Cr. @ Skyliner Rd (in pipe) & $\bullet$ pH & $\begin{array}{l}\text {-Some data online. } 90 \\
\text { minute travel time }\end{array}$ \\
\hline \multicolumn{7}{|c|}{ Portland General Electric (PGE)—Contact: Scott Lewis 541-475-1302 } \\
\hline $\begin{array}{l}\text { Relicensing at } \\
\text { Pelton Round Butte }\end{array}$ & •Background Conditions & 1994-Present & various & $\begin{array}{l}\text { Lake Billy Chinook, Squaw Creek, } \\
\text { Fisheries Study }\end{array}$ & •Field parameters & $\begin{array}{l}\text { Some data/reports are } \\
\text { available }\end{array}$ \\
\hline - Temperature & -Status and trends, Compliance & & $\begin{array}{l}\text { Continuous- } \\
\text { Monthly }\end{array}$ & $\begin{array}{l}\text { Deschutes R. inflow to Billy Chinook, } \\
\text { Deschutes R @ Lower Bridge }\end{array}$ & •Temperature & \\
\hline
\end{tabular}


Table 3. Summary of relevant monitoring activities in the Upper Deschutes River Basin—Continued

[D.R., Deschutes River; L.D.R., Little Deschutes River; C.R., Crooked River; Field, field parameter, including temperature, DO, pH, Specific Conductance; Alk, alkalinity; TSS, Total Suspended Solids (evaporated); TDS, Total Dissolved Solids; SS, Suspended Sediment; Nut., Nutrients; Majors, major ions (cations +anions); Bac-T, Bacteria; Benth, benthic invertebrates in wadeable streams; BOD, biological oxygen demand; COD, chemical oxygen demand; CBOD, carbonaceous biological oxygen demand; TOC, Total Organic Carbon; Alk, alkalinity; Note: TSS, TDS, and SS are indicated separately because of methods differences]

\begin{tabular}{|c|c|c|c|c|c|c|}
\hline \multirow{2}{*}{ Issue } & \multirow{2}{*}{ Monitoring program objectives } & \multicolumn{2}{|c|}{ Time frame } & \multirow{2}{*}{$\begin{array}{l}\text { Spatial coverage in upper } \\
\text { Deschutes River Basin }\end{array}$} & \multirow{2}{*}{ Constituents } & \multirow{2}{*}{ Remarks } \\
\hline & & Period & Frequency & & & \\
\hline & $\cdot$ & & & & & \\
\hline \multicolumn{7}{|c|}{ U.S. Bureau of Land Management (BLM)—Contact: Michelle McSwain 541-416-6474, Brent Falston } \\
\hline \multirow{5}{*}{$\begin{array}{l}\text {-Temperature/ } \\
\text { Irrigation } \\
\text { Withdrawals }\end{array}$} & \multirow[t]{5}{*}{-Temperature standards compliance } & •1993-96 & •2-hour & •D.R. near Cline Falls State Park & \multirow[t]{5}{*}{ •Temperature } & \multirow{5}{*}{$\begin{array}{l}\text {-Also have riparian } \\
\text { vegetation data for } \\
\text { D.R. @ Steelhead } \\
\text { Falls } \\
\text { •No exceedances noted } \\
\text { for temperature }\end{array}$} \\
\hline & & $\bullet 7 / 96-9 / 98$ & •2-hour & •L.D.R. @Hwy 97 & & \\
\hline & & & $\cdot 2$-hour & •Crescent Cr @ Hwy 97 & & \\
\hline & & 1996-present & & •D.R. at Steelhead Falls & & \\
\hline & & 1995-present & & •D.R. at Geneva & & \\
\hline \multicolumn{7}{|c|}{ U.S.D.A. - Forest Service, Deschutes National Forest—Contact: Mollie Chaudet 541-383-4769; Tom Walker 541-383-4787; Robert Rock 541-416-6573, Ochoco NF } \\
\hline - Temperature & •Baseline, status and trends, compliance & •1991-present & $\cdot$ Continuous & $\begin{array}{l}\text {-D.R. from Bend to headwaters, including } \\
\text { tributaries } \\
\text { •L.D.R., Crescent Cr., Squaw Cr., }\end{array}$ & $\begin{array}{l}\text {-Temperature from } \\
\text { thermographs }\end{array}$ & -Uses DEQ protocols \\
\hline $\begin{array}{l}\cdot \text { Eutrophication } \\
\text { (pH / DO) }\end{array}$ & •Baseline, status and trends, compliance & $\bullet$ •1998-99 & $\begin{array}{l}\cdot \text { Monthly } \\
\text { (Apr-Oct) }\end{array}$ & •Squaw Creek & $\bullet \mathrm{pH} / \mathrm{DO}$ & - One time study \\
\hline \multirow{3}{*}{ • Stream Surveys } & $\begin{array}{l}\text { - Baseline, status and trends } \\
\text {-Biological - Invertebrates }\end{array}$ & •1991-present & $\begin{array}{c}\cdot 1 \mathrm{x} \text { every } 2 \text { yrs } \\
\text { at each site }\end{array}$ & $\begin{array}{l}\text {-D.R. from Bend to headwaters, including } \\
\text { tributaries }\end{array}$ & •Benthic macroinvertebrates & $\begin{array}{l}\text {-Analyzed at BLM in } \\
\text { Logan, UT }\end{array}$ \\
\hline & & & & •L.D.R., Crescent Cr., Squaw Cr., & & $\begin{array}{l}\text {-Protocols and QA data } \\
\text { available }\end{array}$ \\
\hline & $\begin{array}{l}\text {-Baseline, status and trends, compliance } \\
\text { • Fine sediment, Habitat }\end{array}$ & •1991-present & $\begin{array}{c}\cdot 1 \mathrm{x} \text { every } 2 \mathrm{yrs} \\
\text { at each site }\end{array}$ & $\begin{array}{l}\text {-D.R. from Bend to headwaters, including } \\
\text { tributaries } \\
\text {-L.D.R., Crescent Cr., Squaw Cr., }\end{array}$ & •Fine sediments & $\begin{array}{l}\text {-Protocols and QA data } \\
\text { available }\end{array}$ \\
\hline -Turbidity & $\cdot$-Compliance, Cause and Effect & $\begin{array}{l}\text { 1992-98 } \\
\text { (March-June/ } \\
\text { July) }\end{array}$ & $\begin{array}{l}\cdot>4 \mathrm{x} \text { per day, } \\
\text { based on } \\
\text { flow changes }\end{array}$ & $\begin{array}{l}\text {-Primarily } 2 \text { stations: D.R. below } \\
\text { Wickiup, D.R. @ Sheep Mtn Bridge } \\
\text { •Some data at other locations }\end{array}$ & $\begin{array}{l}\text { Turbidity from ISCO } \\
\text { samplers }\end{array}$ & •No QA data available \\
\hline -Instream flow & •Evaluate fish habitat at different flows & $\begin{array}{l}\cdot 1991 \text { (Spring- } \\
\text { Summer) }\end{array}$ & $\begin{array}{l}\text {-One time } \\
\text { study }\end{array}$ & •Deschutes R. from Sunriver to Wickiup & •Flow & •Report available \\
\hline \multicolumn{7}{|c|}{ U.S. Bureau of Reclamation, Pacific Northwest Region—Contact Larry “'Zak” Zakrajsek, 541-389-6541 } \\
\hline •Lake quality & -Baseline, status, and trends, compliance & •1984-present & $\begin{array}{l}\cdot 1 \mathrm{x}, \text { every } 3 \\
\text { years }\end{array}$ & $\begin{array}{l}\text {-Wickiup Reservoir (1 station, 3-4 depths) } \\
\text {-Crescent Lake (1 station, 3-4 depths) }\end{array}$ & $\begin{array}{l}\text { •temperature/pH/DO/Sp. C } \\
\text { •Inorganic chemistry, chl a }\end{array}$ & $\begin{array}{l}\text { Data available on } \\
\text { STORET }\end{array}$ \\
\hline \multicolumn{7}{|c|}{ U.S. Geological Survey, Water Resources Division (USGS, WRD)_Contact: Chauncey Anderson 503-251-3206, Dave Morgan (503-251-3263) } \\
\hline -Streamflow & •Basic data collection & 1952-present & Continuous & •D.R. near Culver & -Streamflow & •No other current sites \\
\hline $\begin{array}{l}\text { - Ground water in } \\
\text { La Pine }\end{array}$ & $\begin{array}{c}\text {-Evaluation of land use contributions to } \\
\text { nitrate in } \mathrm{GW} \text {, model development }\end{array}$ & 1999-present & $\begin{array}{l}\text { One time } \\
\text { study }\end{array}$ & $\begin{array}{l}\text {-La Pine area, including Upper Deschutes } \\
\text { (above Bend) and Little Deschutes }\end{array}$ & $\begin{array}{l}\text {-Ground-water level and } \\
\text { flow patterns, nitrate }\end{array}$ & $\begin{array}{l}\text { Just beginning. Also } \\
\text { trying to look @ } \\
\text { nitrate transport to } \\
\text { near-stream zones }\end{array}$ \\
\hline $\begin{array}{l}\text {-Regional ground-water } \\
\text { flow patterns }\end{array}$ & $\begin{array}{l}\text {-Status and trends, } \\
\text { Model development }\end{array}$ & $1994-98$ & $\begin{array}{l}\text { One time } \\
\text { study }\end{array}$ & $\begin{array}{l}\text { Above and including L. Billy Chinook, } \\
\text { including Metolius, Crooked, Upper } \\
\text { Deschutes, \& Little Deschutes }\end{array}$ & $\begin{array}{l}\text { Ground-water level, field, } \\
\text { alk, nut, majors, TSS, } \\
\text { Isotopes of H and O }\end{array}$ & $\begin{array}{l}2 \text { reports completed } \\
\text { (OFR 97-197, } \\
\text { WRIR 97-4233) } \\
\text { •Modeling report in } \\
\text { progress }\end{array}$ \\
\hline
\end{tabular}


Department of Environmental Quality, 1988) included severe effects on beneficial uses in various reaches from flow alterations, turbidity, low dissolved-oxygen concentrations, sedimentation, and toxic chemicals; however, specific causes and the exact magnitudes of these problems were not identified. Rapid growth in the towns of Bend and Redmond and in the southern part of Deschutes County threaten to compound these issues in the future.

Bull trout are federally listed as "threatened" species and redband trout are federally listed as "sensitive" in the middle and upper Deschutes River Basin (Steven Marx, Oregon Department of Fish and Wildlife, written commun., 2000). Although these listings are not necessarily due to water-quality problems, their management is often intricately linked with management of waterquality issues in the basin. Aquatic species included in management considerations are indicated in table 4 . These species are not resident in all water bodies, but are locally concentrated.

Also indicated in table 4 are certain introduced fish species and an amphibian (bullfrog) which, in some cases, may be problematic because of competition with native fish.

\subsection{Recent and Current M onitoring}

Current monitoring activity in the middle and upper Deschutes River Basin (table 3 ) is determined by the priorities and missions of the individual agencies, but monitoring activities generally are not coordinated among agencies. The largest amount of data is collected for streamflow, primarily measured by OWRD, and for temperature, which is measured by several entities. Aside from flow and temperature, the ODEQ's Ambient Monitoring Program, a statewide program with five stations in the Deschutes River Basin upstream of Lake Billy Chinook is the most stable ongoing water-quality monitoring program in the basin. It is therefore a logical foundation around which more comprehensive, integrated water-quality monitoring can be structured. Data from the Ambient Monitoring Program have periodically been analyzed and made available through the Oregon Water Quality Index (OWQI), which provides a measure of trends in water quality at each location (Oregon Department of Environmental Quality, 1999d). Ambient
Monitoring Program data are used in conjunction with data from other sources for regulatory purposes, including decisions about listing specific water bodies on the State's 303(d) list and for setting TMDLs. However, the OWQI alone is not used for regulatory purposes because it is not rigorously designed for those purposes. Rather, the OWQI can provide a general overview of water quality at a site, including trends over time and identification of noteworthy features.

Localized but relatively complete and longterm data have been collected by the City of Bend for its drinking water intake from Tumalo Creek, including the only continuous monitoring of $\mathrm{pH}$ in the study area (table 3). Since 1994, Portland General Electric has collected and continues to collect a variety of basic water-quality data, at locations near the lower end of the study area in support of their management of Lake Billy Chinook and the lower Deschutes River. Stream inventories to document habitat features and physical measures of stream channels are regularly conducted by the Forest Service and the Bureau of Land Management, for Federal lands along most of the stream reaches included in this plan. For Wickiup Reservoir and Crescent Lake, the Bureau of Reclamation takes summertime samples for inorganic water chemistry and chlorophyll $a$ at multiple depths, at intervals intended to be roughly 3 years.

In addition to the above ongoing programs, there is a wide variety of project-oriented data collection to address specific issues or evaluate the effects on streams from resource management changes. Typically, these have been short-term studies, lasting at most about 3 years. Many such studies have been oriented towards stream temperature; the Bureau of Land Management, Forest Service, Oregon Department of Environmental Quality, Oregon Water Resources Department, Oregon Department of Fish and Wildlife, and U.S. Geological Survey have all collected temperature data for various purposes at some time within the last 10 years. The Oregon Department of Environmental Quality conducted a 1995-96 water-quality survey of the upper Deschutes River Basin, including water chemistry from over 20 
Table 4. Historical and current fish and amphibian species in the waters of the upper Deschutes River Basin [Source: Oregon Department of Fish and Wildlife, 1996]

\begin{tabular}{|c|c|c|c|c|}
\hline Common name & Scientific name & Origin & Status & Abundance \\
\hline Pacific lamprey & Entosphenus tridentatus & indigenous & extinct & Not applicable \\
\hline Summer steelhead & Oncorhynchus mykiss & indigenous & extinct & Not applicable \\
\hline Chinook salmon & Oncorhynchus tshawytscha & indigenous & extinct & Not applicable \\
\hline Redband trout & Oncorhynchus mykiss & indigenous & present & moderate $^{\mathrm{a}}$ \\
\hline Bull trout & Salvelinus confluentis & indigenous & present & 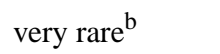 \\
\hline Mountain whitefish & Prosopium williamsoni & indigenous & present & very abundant \\
\hline Shorthead sculpin & Cottus confusus & indigenous & present & locally abundant \\
\hline Reticulate sculpin & Cottus perplexus & indigenous & present & unknown \\
\hline Longnose dace & Rhinichthys cataractae & indigenous & present & low \\
\hline Chiselmouth & Acrocheilus alutaceus & indigenous & present & moderate \\
\hline Largescale sucker & Catostomus macrocheilus & indigenous & present & locally abundant \\
\hline Bridgelip sucker & Catostomus columbianus & indigenous & present & moderate \\
\hline Northern pikeminnow & Ptychocheitus oregonensis & indigenous & present & moderate \\
\hline Crayfish & Pacifastacus leniusculus & indigenous & present & abundant \\
\hline Coho salmon & Oncorhynchus kisutch & introduced & present & locally abundant \\
\hline Kokanee & Oncorhynchus nerka & introduced & present & abundant \\
\hline Atlantic salmon & Salmo salar & introduced & present & rare \\
\hline Rainbow trout & Oncorhynchus mykiss & introduced & present & abundant \\
\hline Brown trout & Salmo trutta & introduced & present & abundant \\
\hline Brook trout & Salvelinus fontinalis & introduced & present & abundant \\
\hline Cutthroat trout & Oncorhynchus clarki lewisi & introduced & present & moderate \\
\hline Lake trout & Salvelinus namaycush & introduced & present & low \\
\hline Largemouth bass & Micropterus salmoides & introduced & present & moderate \\
\hline Smallmouth bass & Micropterus dolomieui & introduced & present & low \\
\hline White crappie & Pomoxis annularis & introduced & present & low \\
\hline Black crappie & Pomoxis nigromaculatus & introduced & present & low \\
\hline Brown bullhead catfish & Ictalurus nebulosus & introduced & present & locally abundant \\
\hline Bluegill & Lepomis Macrochirus & introduced & present & moderate \\
\hline Three-spine stickleback & Gasterosteus aculeatus & introduced & present & very abundant \\
\hline Tui chub & Gila (Siphateles) bicolor & introduced & present & very abundant \\
\hline Blue chub & Gila (Gila) coerulea & introduced & present & locally abundant \\
\hline Bullfrog & Rana catesbeiana & introduced & present & unknown \\
\hline
\end{tabular}

${ }^{a}$ Federally listed as "sensitive."

bFederally listed as "threatened."

locations, and a 1998 study as part of R-EMAP (Regional Environmental Monitoring and Assessment Program) for water chemistry, aquatic biota, and habitat features. Although the data are available, only the water-chemistry findings from the R-EMAP study have been published (Oregon Department of Environmental Quality, 1999e). The Forest Service has performed studies to assess eutrophication, turbidity, flow regulation, and instream flows, as well as numerous smaller scale studies to evaluate the effects of specific forestmanagement projects in the basin. The U.S. Geological Survey has done studies in the basin to investigate sediment erosion and transport below Wickiup Dam, geothermal and water quality aspects of Newberry Crater (Morgan and others, 1997), and regional ground-water chemistry and flow patterns, but has no long-term data-collection 
program in the basin other than one stream-gaging station on the middle Deschutes River near Culver, upstream of Lake Billy Chinook. Finally, the Oregon Department of Fish and Wildlife has done various short-term studies to evaluate its habitat enhancement program or to measure temperature in important reaches, but does not regularly collect water-quality or physical stream geometry data at any locations in the basin (S. Marx, Oregon Department of Fish and Wildlife, oral commun., November 1999).

Despite the relatively large amount of data collection done in the basin over the last decade and continuing to this day, there is a lack of published or otherwise available information on most of these studies. In fact, data from many of the studies have not been analyzed and are not likely to be disseminated to other agencies or the public without specific requests. In some cases, individual agencies do not have a good inventory of the data they themselves have collected, for disparate programs and for various objectives among scattered offices, so it is not surprising that data analysis efforts are often incomplete. This lack of communication of study data is a fundamental area in which current monitoring and data-collection programs in the basin can be substantially improved.

\subsection{Previous Management Plans}

This regional monitoring plan has been developed with consideration of monitoring recommendations from previous management plans that apply to the same study area. These plans range from general, overarching plans, such as the President's Northwest Forest Plan (U.S. Fish and Wildlife Service, 1992) and the Oregon Plan for Salmon and Watersheds (State of Oregon, 2000), to more locally derived and specific plans such as the Forest Service's Comprehensive Management Plan for the Upper Deschutes Wild and Scenic River and State Scenic Waterway (U.S. Forest Service, 1996a). These plans were examined for recommendations relevant to monitoring in the middle and upper Deschutes River Basin, and their recommendations are compiled in Appendix A-1. For the most part, those recommendations were general in nature, so the monitoring actions crafted for this regional plan do not contradict those in the previous plans.

\subsection{Principles of Long-Term Monitoring}

For a monitoring program to be successful, it must be both focused and relevant to regional issues. Because of limitations of funding and other resources, monitoring cannot be all things to all people, but rather must adhere to an agreed upon set of principles. The following principles for monitoring in the middle and upper Deschutes River Basin are modified from those established by the Lower Columbia River Estuary Program (1999) and the San Francisco Estuary Project (1993):

1. Monitoring is focused on the development of data that will provide information on status and trends in the study area.

To understand the need for changes in management of resources in the study area and the effect of such changes, it is important to be able to define current conditions in the river, including their natural variability in space and time, and to recognize any long-term changes in these conditions. This monitoring plan was developed with the two-fold intent of helping to define both the current state of selected environmental variables and their rate of change, if any. These variables represent important aspects of the river to monitor over time in order to assess the integrity of the river's ecological system.

2. A variety of special studies will be needed, both in the short term and over the long term, to fill key data gaps.

There is a need for short and long-term investigations of specific issues in the middle and upper Deschutes River Basin, especially focusing on the mechanisms by which certain environmental processes occur. In many cases the results of these investigations may be critical to understanding or implementing certain aspects of the monitoring plan itself, and this document includes recommendations for several such investigations. However, regional monitoring alone cannot be expected to determine cause and effect relationships among human actions and responses in rivers and streams. Rather, results of monitoring will most likely provide an indication of change (or conversely, no change) in some 
constituent of interest over a specified area and period of time, with the cause of that change being uncertain. Likewise, the monitoring plan cannot encompass all possible known or unknown contaminant sources, and the plan is therefore designed to highlight general areas of concern rather than specific sources. Thus, many useful studies will be beyond the scope of this plan, and it will be incumbent on those implementing and coordinating the plan to recognize efforts more appropriately left to a research or targeted approach. Such studies ideally will provide information for management purposes and to improve or modify the monitoring plan. A commitment from key organizations and agencies to seek funding for special studies will therefore be critical.

\section{Commitment to development of an integrated plan utilizing ongoing programs will be necessary.}

One of the key roles of the monitoring plan is to bring together diverse monitoring data from the middle and upper Deschutes River Basin to enhance the overall understanding of the system. Numerous entities have collected and continue to collect data along the river, but no institutional framework exists to provide a linkage for these various data-collection and assessment efforts. The monitoring plan provides an opportunity to connect these disparate efforts under the umbrella of one organization.

With this in mind, the monitoring plan has been developed with the intent of utilizing existing and planned monitoring programs as its cornerstone. In this way, duplication of effort will be minimized and available resources maximized. Existing programs that have been reviewed and considered are listed in table 3 and explained in greater detail in the topical sections. Compliance monitoring and National Pollution Discharge Elimination System (NPDES) programs are data sources that can augment information collected by the monitoring plan. Additional monitoring beyond the scope of this plan will likely be needed by most agencies to meet their specific organization's objectives. Data collected under this plan will therefore provide a basis for longterm data analysis and provide a regional context for evaluation of more detailed, agency-specific data.

In some cases, standardized approaches to sampling and analysis are specified in the plan, and their use by the respective agencies is highly encouraged; however, some agencies may be reluctant to change methods because such changes would make it difficult to compare newly collected data with historic data collected by different methods. In these cases, it is critical to collect adequate quality-control data in order to evaluate the comparability of data among agencies. Furthermore, it is equally critical to report and review quality-control data on a regular basis to ensure that data being collected are of known quality and can be interpreted in conjunction with other monitoring data.

\section{Establishment of a mechanism for coordinating regional monitoring will be necessary.}

This monitoring plan provides a framework for coordinated monitoring in the middle and upper Deschutes River Basin; however, such monitoring is not likely to be fully implemented without a dedicated mechanism to help to promote it. This mechanism may take the form of a separate oversight entity or a well developed and supported series of agreements among organizations, but in either case it will require diligence. There will be needs for securing funding, developing interagency agreements, contracting for special studies, developing or reviewing quality-assurance plans, verifying that agreed upon monitoring takes place, communicating and discussing study findings, and determining new studies or adjustments to monitoring. All of these activities, and more, will require a substantial commitment of time and resources in order to accomplish them.

5. A strategy for management of data is necessary to ensure access to essential information.

A common problem in comparing or analyzing data among different agencies and investigators is lack of compatibility of the datamanagement systems themselves. In the case of the middle and upper Deschutes River Basin, historical data are located in diverse paper reports 
or computer systems, and in most cases metadata (information defining the type, objectives, and quality of data themselves) are not readily available. Although all these historical data may not be available from a common electronic source in the short term, it is important that newly collected data be maintained by the agency collecting them in a format that is accessible by other participating agencies. It is also advisable to summarize the data and make it available to the public.

\section{A periodic assessment of monitoring data and reevaluation of the monitoring plan will be required to ensure success of the plan.}

As a mechanism to ensure continued attention and commitment to monitoring in the study area and to keep the monitoring plan appropriately focused, regular reviews of progress and findings of the plan will be essential. While it is widely recognized that monitoring is necessary to understand the effects of changes in systems, there is often a lack of followup to monitoring efforts, and hence funding for monitoring programs has been reduced or eliminated because their potential benefits have not been realized. Periodic reassessments will provide a continued emphasis on monitoring and opportunities to educate agencies as well as the public about the benefits of the monitoring program.

The various aspects of the monitoring plan will not necessarily require the same intervals of time between periodic assessments. An annual meeting or workshop is suggested for review of monitoring data and progress, including review and assessment of quality-control data. Participants in the meeting would include the Watershed Council and agencies participating in monitoring or otherwise collecting data in the study area. At a longer interval, the overall efficacy and design of the plan would be assessed, in addition to more thorough analysis of monitoring data to evaluate status, trends, and compliance with standards for specific constituents. At least 5 years of data could be required to detect trends in most response variables, though this time may vary from as little as 3 years to longer than 10 years. The time required to detect changes ultimately will depend on the degree of change desired, sampling frequency, and natural variability, including occurrence of extreme or episodic climatic events such as floods or droughts. In general, a period of 5 years has been accepted as the logical reassessment interval for the monitoring plan itself. As the plan is initially phased in, some operational changes will likely be required in response to emerging logistical or funding constraints.

7. Successful monitoring will require active participation of key entities and individuals

There are many agencies and organizations involved in jurisdiction or influence of one or more aspects of river management. Each has specific purposes for its involvement with the river, and sometimes these purposes conflict among different organizations. Although not all of these organizations have been directly involved in the watershed council or the development of the monitoring plan, the number of organizations involved remains large, and avenues for input from other organizations must remain open. In this setting, a monitoring program can be most successful if it has the involvement and support of the many agencies charged with its implementation or affected by its findings. Training in the use of common methodologies among monitoring organizations may at times be necessary. Managers and scientists representing affected agencies and other organizations will need to periodically review the goals, technical merits, and findings of the monitoring plan, incorporating input from the public wherever possible.

\subsection{Coordinated, Regional Monitoring Plan}

Many of the suggested monitoring actions contained in this plan are concerned with basic aspects of monitoring, namely quality assurance, analysis, and communication of existing data. In fact, the existing monitoring programs being conducted by individual organizations appear relatively sound, providing a good structure around which to base more comprehensive and coordinated monitoring, without large data gaps or overly unnecessary overlap between agencies. 
However, for almost all issues considered herein, there is an apparent need to inventory existing data within and across agencies and to assess the suitability of available data for analysis at a regional scale, to complete data analysis, and (or) to communicate the results of those analyses. The processes of completing these steps will help to clarify where the monitoring network is adequate and where there are data gaps.

In general, it is not advisable to initiate new monitoring without doing some preliminary analysis of existing data. This analysis could enhance understanding of system processes and help to determine the frequency and spatial coverage of sampling necessary to achieve a desired resolution in the acquired data; conversely, it could also help define the ability of a practical level of monitoring to provide acceptable resolution for a given issue. In the case of the middle and upper Deschutes River Basin, ongoing monitoring programs and previously conducted studies might provide a good basis for making these determinations. It is not suggested that all monitoring cease until the networks have been optimized. Rather, it is suggested that ongoing monitoring continue, largely in its current form, with several modifications and selected special studies indicated in subsequent sections. Data on variability of different properties of water would then be available for a statistical network design when such an effort can be commissioned.

In the following sections water-quality issues in the study area are described, and monitoring objectives and associated actions are listed with brief explanations. The objectives and their actions are organized according to the type of monitoring addressed, such as Status and Trends, Compliance, or Evaluation monitoring. In many cases, a more basic set of objectives and actions has also been added; these are primarily oriented towards increasing the utility of data that have already been or are currently being collected. Following the listing of objectives and suggested monitoring actions associated with them, the rationales for each action are explained.

\subsection{M onitoring Program M anagement}

Certain steps can be taken to enhance the likelihood of success in meeting the goals for regional monitoring. These steps fall generally into the categories of increasing integration and efficiency of current monitoring efforts among agencies, filling data gaps, and communicating available information.

\subsubsection{Objectives and Associated Actions}

\subsubsection{Integration, Coordination, and Efficiency}

There are several general actions that can be taken to improve the foundation and increase the efficiency of monitoring in the study area. Some follow directly from the principles listed in section 2.7 .

Objective: Integrate existing monitoring efforts among participating organizations to increase efficiency, minimize redundancy, and improve data quality and comparability, to the extent possible, by:

Action 1: Establishing a mechanism for coordinating and supporting the long-term execution of the middle and upper Deschutes River Basin monitoring plan, and tracking major changes in management or land use in the basin in relation to monitoring;

Action 2: $\quad$ Periodically reviewing progress for the regional monitoring plan, with suggested annual and 5-year intervals, to determine if monitoring elements are being carried out, evaluate monitoring data and results, and modify the design and priorities of the monitoring as needed;

Action 3: Establishing common protocols that enable data comparison among agencies and that are consistent with objectives for data collection;

Action 4: Developing quality-assurance plans for each major monitoring element; 
Action 5: Establishing a data management strategy that allows data and databases developed under this plan to be shared among agencies and other interested parties, provides information regarding the type and quantity of data collected, and is easily used; and

Action 6: Working to increase availability of information, reports, and other products to other agencies and the public.

\subsection{Rationale and Explanation}

\section{Action 1: Establish coordinating}

mechanism-As mentioned previously, a process for coordination and discussion of monitoring issues is critical to the long-term success of any regional, integrated monitoring effort among agencies. If coordination is to be done by one organization, the most likely candidates, for example, are the Bend office of the Oregon Department of Environmental Quality, the Bend/Fort Rock Ranger District of the Forest Service, or the Upper Deschutes Watershed Council. A watershed council might be the most appropriate because it provides a forum for public deliberation that is not associated with the mandates of any particular agency but rather with the broad participation of private citizens, businesses, nonprofit organizations, and public agencies. A watershed council can also be instrumental in securing additional funding from grants or other sources, helping to ensure that member agencies participate actively in various aspects of the monitoring plan, and in general act as a strong advocate for the basin as a whole.

A possible drawback to a watershed council as a coordinating entity is that they are a relatively new component in water management in Oregon. The long-term existence and role of these councils is not yet certain, whereas the roles and mandates of State or Federal agencies are likely to be more stable for many years. Ultimately, the decision of which organization will manage regional monitoring according to this plan, and how such management will be done, is beyond the scope of this plan. However, due to the importance of this task in moving forward with coordinated monitoring in the region, it is already being addressed by the monitoring committee.

\section{Action 2: Conduct periodic progress}

reviews-If monitoring is to remain viable, it must be flexible enough to adapt to changes in regional priorities or other aspects of water-quality management. There is no way to anticipate all of the issues and other questions that monitoring may be asked to help answer in coming years.

However, most changes to monitoring will need to be made on the basis of information gleaned from previous data-collection efforts. Periodic, planned reevaluation of the monitoring program is therefore suggested, at two different time scales: (1) Annual reviews would be used to assess and communicate the progress of monitoring, the quality of data collected, and any immediate findings such as violations of water-quality standards or emergence of new issues. A workplan for the following year, with priorities and agency responsibilities for upcoming monitoring actions, would also be determined. (2) Every fifth year the reassessment would include a more substantial analysis of data by the participating organizations. Topics for analysis would include, in addition to the annually examined aspects of the plan, an evaluation of trends in the data, effects of resource management, synthesis of data from multiple monitoring tasks (for example the relation of sediment transport to nutrient loading), and recommendations for modifications to the monitoring program. Changes in regional water management priorities, such as monitoring load allocations resulting from TMDLs, could be reflected in changes in the long-term monitoring program. This larger reassessment will also provide an opportunity to communicate to managers and to the public the findings and benefits of the area's monitoring efforts. For some water-quality measurements, such as those collected continuously (temperature, turbidity, or others), 5-year intervals might be long enough to observe trends or make other conclusions about river processes or relations of management actions to water quality. For other issues, such as channel geometry, for which sampling is much less frequent or natural variability is high, real trends may take decades or more to observe. 
Action 3: Establish common protocolsThe use of common, clearly defined protocols for sample collection, processing, and laboratory analysis is important wherever possible to ensure the comparability of data collected by different organizations or over time within an individual organization. Data for water-quality constituents with the same or similar names often represent different measurements of water quality because of small but important operational differences in their collection, such as sample filtration and preservation techniques, and instrument calibration procedures.

\section{Action 4: Develop quality assurance} plans-Quality assurance (QA) plans will be critical to the success of monitoring. Good quality-control (QC) data, and assessments of those data, can allow the comparison of data among agencies and over time, whereas poor quality-control data can prevent such comparisons. As part of the implementation of the monitoring plan, an important task for each component of the plan, based on the principles outlined previously, would be the development of a detailed QA plan - an example is given by ODEQ at http://waterquality.deq.state.or.us/wq/ 303dlist/QAPPExample.htm. It is the goal of all QA programs to provide environmental data, using multiple sampling crews and analytical laboratories, with quantifiable bias, variability, and representativeness, along with appropriate detection levels, that will allow all data to be comparable within a single dataset and of a sufficient quality to meet the objectives of the monitoring plan. The three important components of quality assurance in any monitoring plan are quality-assurance elements, quality-control data, and quality assessment. These are the planned and systematic procedures necessary to provide adequate confidence about monitoring data to satisfy data-quality objectives. Quality assessment, or the actual inspection of qualitycontrol and environmental data after its collection, is an important aspect and is often overlooked. Without assessments, simple details can be missed. For example, if continuous monitors are not logging the proper time (including a.m. or p.m.), subsequent data will be of marginal value. More detailed definitions of QA/QC elements and their components are provided in Appendix B.
The development and utilization of good quality-assurance plans will be particularly important where protocols are not completely in agreement among different entities involved in data collection. Such situations could arise if one organization has an interest in using a particular protocol, because of historical or geographically widespread databases of data collected with that specific protocol, or because of legal or agency specific mandates. In these cases it will be especially important to verify that data collected by multiple organizations using differing protocols are comparable. A good qualityassurance plan can help quantify precision, accuracy, representativeness, and biases among the different methods to understand the limitations of data comparisons. Examples would include protocols on calibration, acceptable tolerances, and data management for the use of meters to measure turbidity, $\mathrm{DO}, \mathrm{pH}$, and temperature, or documentation of the laboratory techniques, precision, and bias for nutrient analysis.

Action 5: Establish a data management strategy - In order for monitoring data to be used to assess status and trends, compliance, management effectiveness, and the monitoring plan itself, those data will need to be available. An agreed-upon strategy for data management would enhance the ability of different organizations to have access to monitoring data. Issues requiring discussion will include both programmatic and institutional issues as well as technical issues. Programmatic and institutional issues include funding and staffing, and agreement on data sharing and data standards. Technical issues include system location, operation and maintenance, system compatibility, database design (for example, centralized or dispersed), and data accessibility. These issues are discussed in more detail by the Lower Columbia River Estuary Program (Lower Columbia River Estuary Program, 1998) in regards to similar data management needs.

Action 6: Increase data availabilityOne of the measures of success of the monitoring program will be the degree to which the data collected, and the findings resulting from them, are used. Users of data can include the data-collection agencies themselves, other 
organizations involved in the monitoring plan, water managers in the region, and the public. Water managers and the public are most likely to use interpretations resulting from the monitoring plan rather than raw data, produced by the collecting agencies as data analyses, written reports, and other products. Including these end users as part of the data-collection and interpretive process increases the relevance of the monitoring program and the likelihood of its continued support by the involved organizations and public alike. This suggestion is differentiated from Action 5 by its emphasis on results and analysis in order to provide information to the public. Action 5 is more oriented towards the mechanics of making monitoring data available among agencies or other researchers for the purposes of analysis.

\subsubsection{Data Gaps}

\section{Objective: Identify large gaps in data from existing monitoring efforts that can be filled with minor modifications to existing programs, and}

Objective: Identify data gaps or other research deficiencies that limit or prevent success of additional monitoring efforts, by:

Action 7: $\quad$ Analyzing and communicating data from previously completed studies in the Deschutes River Basin to help formulate baselines and refine issues.

\subsection{Rationale and Explanation}

Action 7: Analyze existing data-As is commonly the case, much of the data collected in the study area either have not been analyzed at all or have been analyzed only sparingly. Analysis of these data in a series of more comprehensive undertakings would provide many benefits to future monitoring as well as to water managers in the basin. Results from these studies could be used individually and collectively to (1) help answer the questions they originally were intended to address, (2) formulate hypotheses regarding water-quality processes or sources of contaminants in the basin, (3) evaluate the value of those data as components of future monitoring, (4) evaluate the qualityassurance practices of the collecting organization and the reliability of the data, (5) provide data for determination of the status of a resource or a baseline for future determinations of trends, and (6) identify important data gaps in the current monitoring programs in order to make appropriate modifications for future monitoring. Among the potentially available datasets are studies by ODEQ in 1995 and 1996 of water quality in the upper Deschutes River Basin and in 1997 and 1998 (Oregon Department of Environmental Quality, 1999e), as part of the R-EMAP program, data from ODEQ's ongoing Ambient Monitoring program, data from the many temperature monitoring studies conducted previously in the basin (see section 3.3), and data from stream surveys conducted by the Forest Service, BLM, and ODFW for both long-term monitoring purposes and for specific management projects.

\subsection{Streamflow}

Stream discharge is one of the most fundamental components of all water-related investigations. Uses of streamflow data include decision-making for water allocation, irrigation, reservoir storage, and instream-flows; flood forecasting; evaluation of habitat availability or channel change; recreation; determination of constituent loads (streamflow multiplied by concentration); and others. Although streamflow is not generally considered a water-quality constituent itself, it is intricately tied to all other water data, so evaluation of the stream-gaging network in the middle and upper Deschutes River Basin as it applies to water-quality monitoring is included in this plan.

Streamflow in the study area is primarily measured by OWRD, which operates 36 gaging stations upstream of lake Billy Chinook (fig. 3), including those on tributaries and irrigation canals; one stream-gaging station, on the middle Deschutes River near Culver, is maintained by the USGS. More than half of these stations have over 50 years of record. This network of streamflow data makes the flow regime in the basin one of the most completely monitored in the State, which is indicative of the many demands on water in the basin. The middle Deschutes River is the only substantial length of 


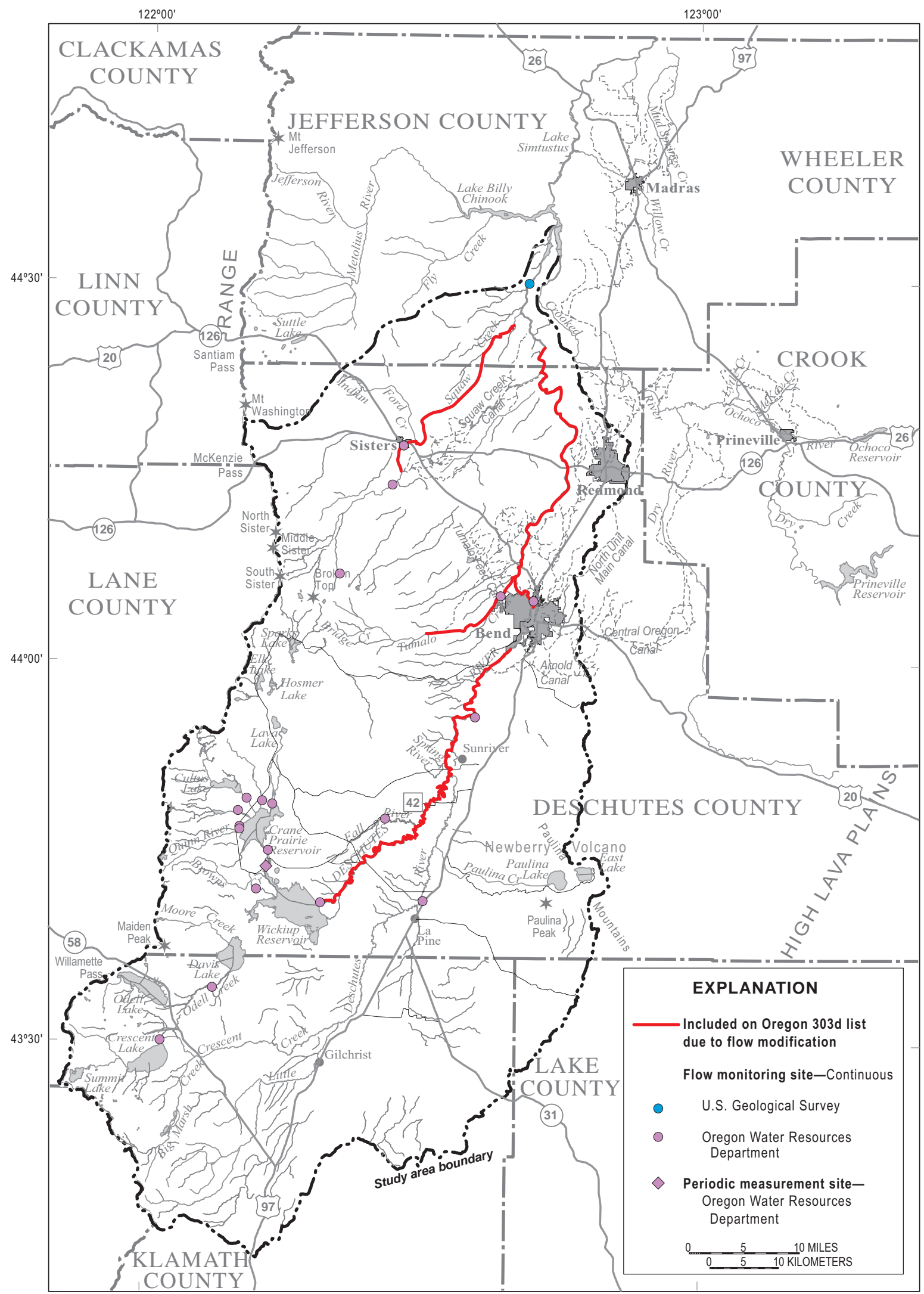

Figure 3. Active stream-gaging stations in the middle and upper Deschutes River Basin, Oregon, 1999. (Stations on canals are not shown.) 
stream in the basin that is ungaged. In the reach from Bend to Lower Bridge there is little groundwater inflow (Gannett and others, in press) so the major addition of water is from Tumalo Creek. Because a gage was reinstalled on Tumalo Creek in 1999, streamflow at Lower Bridge can now be estimated by summing flows from Tumalo Creek and the Deschutes River below Bend. Several reaches, including the Deschutes River from Wickiup Reservoir to Bend, from Bend to Steelhead Falls, Squaw Creek, and Tumalo Creek, are listed on the State's 303(d) list as water-quality limited because of flow modification.

Several stream reaches, most notably the upper Deschutes River from Wickiup Reservoir to the Little Deschutes River (reach 3 in table 2), have higher and fluctuating flows during summer resulting from irrigation water released from reservoirs, and lower flows during fall and winter as water is stored for the irrigation season. These flow modifications cause the timing of stream hydrographic patterns to be shifted seasonally from their natural flow patterns (Cameron and Major, 1987; U.S. Department of Agriculture Forest Service, 1996). Crescent Creek (reach 1) is a 30 mile reach from Crescent Lake to the Little Deschutes River that also is regulated for irrigation purposes, with peak flows occurring in summer (Moffat and others, 1990); however, the Little Deschutes River (reach 2) is unregulated. The Deschutes River at Benham Falls (reach 4), representing the combined flow of the Little Deschutes River (with Crescent Creek) and the upper Deschutes River below Wickiup Reservoir, therefore has peak flows that are only partially shifted in timing from their preimpoundment patterns (U.S. Department of Agriculture, Forest Service, 1996). However, the magnitude of the flow changes remain substantial compared with preimpoundment flows, because most of the water originates from Wickiup Reservoir. These release patterns are propagated downstream with only minor attenuation, until withdrawals from the irrigation canals dominate the streamflow cycles.

A small hydroelectric dam in Bend, which forms Mirror Pond in the city center, is operated by a private power company. Essentially a run-ofthe-river facility (that is, a minor amount of water is stored behind the dam), it does not regulate flow in the middle Deschutes River downstream save for a short bypass reach between the dam and powerhouse, where flows can be as low as 10-15 $\mathrm{ft}^{3} / \mathrm{s}$ (cubic feet per second). Rather, the main issues associated with the dam are fish passage and protection (there is no passage for upstream migration or screening for protecting fish from the turbines), sedimentation, and temperature (Steve Marx, Oregon Department of Fish and Wildlife, oral commun., 2000). Additional water-quality concerns associated with Mirror Pond are discussed elsewhere in this report.

Irrigation withdrawals are also responsible for downstream changes in streamflows. The changes are most significant below the North Unit Main Canal. Although irrigation water rights would allow complete diversion of the middle Deschutes River below the canal (more than 1,000 $\mathrm{ft}^{3} / \mathrm{s}$ ), summer streamflow there is maintained at 30 $\mathrm{ft}^{3} / \mathrm{s}$ through a nonbinding agreement. Groundwater inflows, mostly in the final reach from Steelhead Falls to Lake Billy Chinook (reach 7), rapidly add more than $400 \mathrm{ft}^{3} / \mathrm{s}$ (Gannett and others, in press). Squaw Creek, Tumalo Creek and Paulina Creek also are subject to significant diversions to irrigation canals. Discharge in Squaw Creek often drops from about $90 \mathrm{ft}^{3} / \mathrm{s}$ upstream of the Squaw Creek Irrigation Canal to only a few cubic feet per second through the town of Sisters, with subsequent inflows from Indian Ford Creek, Camp Polk Springs, and Alder Springs (Houslet, 1998). Discharge in Tumalo Creek drops from over $120 \mathrm{ft}^{3} / \mathrm{s}$ upstream to around $2.5 \mathrm{ft}^{3} / \mathrm{s}$ near the mouth during irrigation season, and flows in Paulina Creek rarely (if ever) reach the Little Deschutes River.

\subsubsection{Monitoring Objectives and Associated Actions}

With an extensive flow monitoring network covering most of the basin already in place, flow monitoring objectives for this plan are largely oriented toward increasing the utility of the data currently being collected. Flow data are used by many people for myriad purposes, so actions increasing their accuracy and availability would be well received. Near-real-time data for many of the stations are already available online through the Bureau of Reclamation's Hydromet System (http://www.wrd.state.or.us/surface_water/ realtime). The largest sources of uncertainty in the 
measurement and prediction of discharge are associated with the variability of streamflow that enters the upper Deschutes River as snowmelt (including flood waters) or as ground water, and the large inputs of ground water in the lower portions of the basin. Objectives for monitoring streamflow in the basin are as follows:

\subsubsection{Data Utility and Availability}

\section{Objective: Increase availability of current and historical data to other agencies and the public, by:}

Action 8: $\quad$ Updating streamflow records for all stations and publish data (as paper reports or electronically) to maximize utility of data to other agencies and to the public.

\subsection{Rationale and Explanation}

Action 8: Update streamflow recordsDespite the extensive stream-gaging network in the basin, there is a backlog of uncompleted records at many stations that generally dates to 1992, although relations between discharge and stage are up to date for most stations (Kyle Gorman, Oregon Water Resources Department, written commun., 1999). As a result of this backlog, flow data are obtained primarily by calling the OWRD offices in Bend. In addition to placing a burden on OWRD personnel, this is a time-consuming and potentially expensive step for users of streamflow information and could be a limitation to hydrologic analysis for streams in the basin. Furthermore, streamflow records, including computation of hourly discharge at all flow levels on the basis of stage, are up to date for some highpriority stations but are not completed for all stations in the basin. For the purposes of increasing the completeness and availability of streamflow data in the basin, it is suggested that a concentrated effort be given to bringing these records up to date, publishing the backlogged data, and publishing future records on an annual basis. Streamflow data could be published electronically, including on the World Wide Web, or in paper reports. There undoubtedly will be costs associated with updating streamflow records from previous years, but making these basic data available will help maintain the quality of data collected previously and in the future, as well as provide a valuable service to the public.

\subsubsection{Status and Trends Monitoring}

Objective: Provide flow data, over the range of flow conditions, for use in combination with waterquality data for load calculations, to support evaluation of sources and transport of water-quality constituents, and

\section{Objective: Improve predictive capabilities} for flow entering reservoirs and upper Deschutes River in order to more adequately allocate water resources downstream, by:

Action 9: Continuing to measure flows in all major streams, tributaries, and irrigation canals in the middle and upper Deschutes River Basin;

Action 10: Collocating OWRD stream-gaging locations with ODEQ Ambient Monitoring Stations in order to better combine streamflow and water-quality data; and

Action 11: Developing process-based or statistical hydrologic models to:

-Increase predictability of snowmelt and ground-water systems to reservoirs.

-Increase predictability of groundwater discharge to Fall River and Spring River, and to the middle Deschutes River, by exploring relationships between water levels in select wells and ground-water discharges to rivers. 


\subsection{Rationale and Explanation}

Action 9: Continue current streamflow

network-This action is an acknowledgement that the current streamflow network is both comprehensive and useful. With appropriate dissemination of data, it can provide critical information at important locations for many different users, including irrigators, water resource managers, planners, scientists, and recreationists. With the exception of a few suggested relocations of flow or sampling locations (see Action 10), the current discharge network is highly effective and is not in need of physical changes.

Action 10: Collocate streamflow and water-quality stations-In addition to providing data for water allocation and flood forecasting, streamflow data are used in conjunction with water-quality data to determine transport, sources, and loading of many different constituents of interest. Constituent loads, defined as a mass of material passing a location in a specified time, are determined as the product of streamflow (volume per unit time) and concentration (mass per unit volume). They can be calculated for various purposes using flows averaged on annual, monthly, or daily time steps, or are sometimes determined on an instantaneous basis, especially for peak flows and contaminant transport. In order to provide the greatest utility for the most users, it is desirable to have streamflow gaging stations at the same locations where water-chemistry data are collected.

Alternatively, streamflow data from known upstream sources can be summed for use in estimating constituent loads, but this approach increases uncertainties for shorter time period loadings (for example, peak instantaneous, hourly, or daily loads) because of uncertainties in time-oftravel of flow and from ungaged inflows.

\section{Action 11: Develop hydrologic models-}

There is a need to know how much water in the basin can be used for irrigation in an upcoming growing season while maintaining the required instream flows for fish and other biota. The major sources of water in the basin are snowmelt, which feeds the reservoirs located on the eastern flanks of the Cascades, and ground water. Ground water enters the river system in large amounts through spring-dominated streams feeding the reservoirs, the Fall and Spring rivers, the middle Deschutes River below Steelhead Falls, and the lower Crooked River (outside the study area). Snowmelt also recharges the ground-water system, so the two systems are intrinsically linked. Although ground-water discharges are relatively stable compared to snowmelt, there is nonetheless some annual variability, mostly responding to major variations in precipitation and evapotranspiration in the Cascades from previous years. The variability in both systems increases the uncertainty over the quantities of water available in a given year for various water uses, and makes management of reservoirs more difficult.

Two different types of modeling potentially could be done to increase the predictability for water entering the reservoir system and through ground-water discharges to the rivers. A physically based model linking snowmelt and ground-water hydrology in the Cascades could be developed to improve predictions of inputs to the reservoirs, particularly Crane Prairie and Wickiup Reservoirs. The dynamics of ground-water discharge from the Cascades, including linkages with snowmelt, have already been explored by Manga (1996, 1999); the primary tasks for this modeling effort would therefore be to develop a good network for collecting snowpack data, modify the general models by Manga (1996) to be specific to streams entering the upper Deschutes River reservoirs, and include a component of direct surface runoff from snowmelt based on precipitation and climate data (Gannett and others, in press).

For ground-water discharges to the Fall and Spring Rivers and to the middle Deschutes River below Steelhead Falls, simple statistical regressions between stage in select wells and streamflow could possibly be developed. Groundwater elevations in wells along the margins of the Cascades are known to be highly correlated with discharge in the Fall River, and levels in some wells near Terrebone and Redmond are likely to be highly correlated with discharge to the middle Deschutes River (Gannett and others, in press). Such models might help resolve variability of approximately $100 \mathrm{ft}^{3} / \mathrm{s}$ in the Fall and Spring Rivers, and another $100 \mathrm{ft}^{3} / \mathrm{s}$ in the Deschutes 
River below Steelhead Falls, amounts that could be important in helping to allocate flows during critical periods.

\subsection{Water Temperature}

Maintenance of cold or cool water temperature is critical for most native fishes in the middle and upper Deschutes River Basin, and in particular for salmonids. Accordingly, temperature is the most commonly measured water-quality constituent in the basin, with over 60 locations currently monitored by private and local organizations (City of Bend, Portland General Electric), State agencies (OWRD, ODFW, ODEQ), and Federal Agencies (BLM, Forest Service). About two-thirds of these stations have some form of continuous monitoring, and the remainder are sampled by spot measurements during periodic station visits (fig. 4). The quality of data for these sites is as yet undetermined, however, so their utility in meeting the objectives of the monitoring plan is not fully known. Many additional locations have been used in the past for short-term purposes associated with specific needs (Bonnie Lamb, Oregon Department of Environmental Quality, written commun., 1999).

Across Oregon many streams do not meet State standards for temperature. Within the study area for this monitoring plan, several of the major stream reaches are listed as water-quality limited for temperature (table 2) on the State's 303(d) list, including portions of the Little Deschutes River, Crescent Creek, Paulina Creek, the middle Deschutes River, and Squaw Creek. Where streamflow is high and riparian coverage is good in the basin, temperatures tend to be cooler, whereas streams that have relatively low flow or reduced riparian cover tend to exceed the State maximum temperature standard. The upper Deschutes River from Wickiup Dam down to the Central Oregon Irrigation Canal does meet the temperature standard, most likely as a result of releases of large amounts of cool water from Wickiup Reservoir during summer. Water withdrawals downstream apparently reduce flow below Bend to the point that the river is unable to withstand the effects of solar warming and other heat inputs such as tributary inflows, and the temperature standard is not met. In the final reach below Steelhead Falls, where ground-water inputs increase discharge several-fold, the cool temperature of the additional ground water helps to reduce stream temperatures again to within State standards.

\subsubsection{Monitoring Objectives and Associated Actions}

\subsubsection{Data Utility and Availability}

\section{Objective: Increase availability of existing and future temperature data and analysis for the public and other agencies, by:}

Action 12: Compiling data bases of existing data and evaluating temperature QA/QC data to determine if enough QA data are being collected, if data are of high quality, and if data are comparable between sites and agencies; and

Action 13: Analyzing existing data to determine baseline conditions and look for changes over time, and communicate the results of this analysis to interested agencies and public.

\subsection{Rationale and Explanation}

Action 12: Compile existing data and evaluate QA/QC data-As with most data on water-quality, stream-temperature data have been collected by a wide variety of organizations, using many different methods. Although analysis of existing temperature data, as in Action 13 (see below), is suggested as a basis for any major redesign of the temperature monitoring network, the first step is to inventory available data and determine whether those data are amenable to analysis in the first place. This task could involve creating a database to handle the disparate data, and ensuring that there are adequate quality-assurance data to allow comparison of datasets among agencies and different locations. Quality assurance and other data that may be used to determine the quality of 


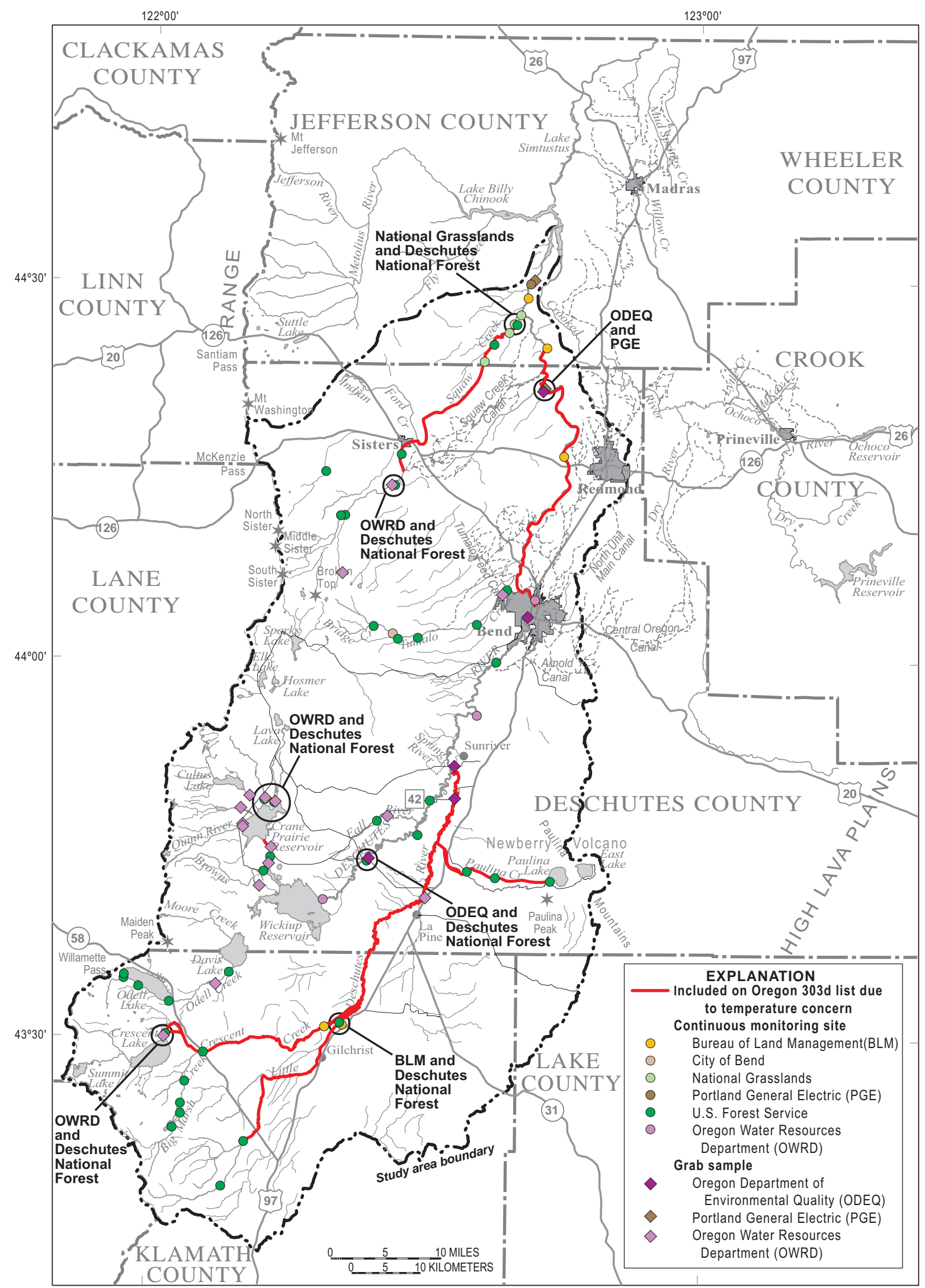

Figure 4. Location of temperature monitoring stations in the middle and upper Deschutes River Basin, Oregon. (Circles indicate redundant monitoring stations by indicated organizations.) 
the temperature data will include (1) instrument type, age, and specifications, (2) calibration frequency, tolerances, and records, to evaluate precision and accuracy, (3) miscellaneous check measurements or other applicable spot measurements from other organizations for comparison, (4) information on the completeness of records, including the amount of missing data, and (5) observations on the location of recording devices or sites for grab samplings, including riparian shading, depth of deployment, and date and time of station visits. The USEPA has already initiated part of this action with a contract for some of the above work (Stuart McKenzie, U.S. Geological Survey [retired], written commun., 1999).

Action 13: Analyze existing data-Once the quality of available temperature data has been documented, an analysis of existing data would prove invaluable for several purposes. In addition to determining whether there have been detectable changes in temperature over time, or changes that can be linked to management actions in the basin, this analysis will help highlight strengths and weaknesses in the current temperature monitoring network. Sites that are redundant or that otherwise provide little useful data, and sites that are critical and that provide highly useful data, will be more evident after this type of analysis.

\subsubsection{Status, Trends, and Compliance Monitoring}

\section{Objective: Determine the spatial}

(longitudinal) variability, diel

and seasonal variability, and

long-term trends of water

temperature, and

Objective: Provide data to determine if water temperatures exceed State standards and to support development of TMDLs for the basin, by:

Action 14: Collecting data for temperature using continuous monitors rather than individual field measurements, where possible, to capture diel and seasonal variations. For temperature field measurements, schedule sampling times to account for diel variations;

Action 15: Modifying the existing temperature network to increase efficiency by removing redundant monitors and installing new monitors to fill data gaps for support of TMDL development; and

Action 16: Developing temperature models for the 303(d) listed reaches, especially Squaw Creek, Little Deschutes River from Crescent Creek to Deschutes River, and Deschutes River from Bend to Lake Billy Chinook, to support development of TMDLs and to determine effects of flow variations from reservoirs, irrigation withdrawals, and other management alternatives on stream temperatures.

\subsection{Rationale and Explanation}

Action 14: Use continuous monitors and modify timing of field sampling-Stream temperature, like $\mathrm{DO}$ and $\mathrm{pH}$, typically exhibits a predictable diel pattern, with increasing temperature during the day and decreasing at night, particularly during summer. Maximum and minimum temperatures occur during late evening and early morning, respectively, with temperature during midday generally representing an average temperature. Exceptions are usually limited to situations where the measurement location is close to a large water source that remains at a relatively constant temperature, such as the outflow of a lake or spring, or where regional ground-water input is important, so that the magnitude of diel cycling is less. The State water-quality standard for temperature reflects this pattern, requiring calculation of a 7-day average of daily maximum temperatures. For long-term, routine sampling programs that do not specifically target daily maximum temperatures, data are accepted for evaluation relative to standards if they are collected during representative seasons (typically summer) and times of day (mid- to late afternoon) (Oregon Department of Environmental Quality, 
1999c). However, for routine monitoring of water quality, when there are often several constituents being measured, or where work is scheduled so as to maximize the number of locations that can be sampled in a day, spot measurements for temperature are often taken without regard to the time of day. Thus, stream temperatures in many existing water-quality datasets are not adequate to assess adherence to temperature standards or trends over time. Wherever possible, temperature sampling under this monitoring plan is best done with calibrated, continuous monitors. Spot measurements for temperatures taken in association with this plan would be best made in the late afternoon or early evening in order to be most applicable to water-quality standards or for trend analysis.

\section{Action 15: Modify existing network-}

With over 60 sites, coverage of temperature monitors in the middle and upper Deschutes River Basin is extensive, perhaps more so than would be warranted solely from the perspective of this regional plan. However, many of these sites, for example those that are located near the headwaters of smaller tributaries or the inflows to reservoirs, are monitored for purposes such as project-level evaluations specific to the individual management organizations. Nonetheless, there are a few locations where temperature is monitored by more than one organization, whereas other relatively long segments of major stream reaches that are on the 303(d) list for temperature have no monitors (fig. 4). Because TMDL development may ultimately depend on temperature data from the 303(d) listed reaches, additional data from these reaches are likely to be useful. Redundant continuous monitors are located in the following two locations:

- Little Deschutes River near Gilchrist (upstream of Crescent Creek). Monitors are operated by the BLM and the Forest Service. One of these could be moved to the Little Deschutes River below the mouth of Crescent Creek so as to provide data on temperatures resulting from the mixing of the two streams.

- Squaw Creek near the mouth. Monitors are operated by the Crooked River National
Grasslands and the Forest Service. Monitors already exists on the Deschutes River downstream of Squaw Creek.

There are also cases where one agency is collecting continuous temperature data and another is making spot measurements for temperature at the same or nearby sites (fig. 4). These include several inflow streams to Crane Prairie and Wickiup Reservoirs, the outflow from Crescent Lake, the Deschutes River at Pringle Falls, Squaw Creek upstream of the Squaw Creek Canal, and others. However, the spot measurements could provide additional checks on the continuous records collected at these stations and are therefore valuable components of a quality assurance program. Furthermore, the spot measurements for temperature are often conducted with other work at the same locations, so they do not in most cases represent substantial additional work. For these reasons it is not suggested that these apparent redundancies be eliminated. Instead it will be important to maintain awareness about these overlaps and to share field and quality assurance data for measurements among agencies. This will allow continuous temperature records to be accurately analyzed.

Some important locations in the basin are monitored using only spot measurements. In particular these include the ODEQ Ambient Monitoring locations on the Little Deschutes River at Highway 42, the Deschutes River at Harper's Bridge, and the Deschutes River at Lower Bridge. Because these reaches are likely to be the subject of TMDLs for temperature, it would be advantageous to install temperature monitors at one or all of them. As an alternative to, or in addition to, the ODEQ site at Lower Bridge, a temperature monitor could be located upstream in the vicinity of Cline Falls to provide temperature data closer to Tumalo Creek in the low-flow section of the river.

\section{Action 16: Develop temperature} models-A reach-based temperature model developed for Squaw Creek by Houslet (1998) indicates that maintaining the natural average flow in the creek would allow temperature standards to be met. However, the model also indicates that the minimum flow determined by Oregon Department of Fish and Wildlife $\left(10 \mathrm{ft}^{3} / \mathrm{s}\right)$, and the current 
flow regime whereby the stream is dry for several miles during summer, prevent Squaw Creek from meeting the temperature standard. The model also indicates that other factors, such as riparian shading, also will help to maintain low temperatures in the upper reaches of the river and that additional flow will increase available trout habitat. For TMDL purposes, higher resolution modeling of stream networks will be needed in Squaw Creek. Temperature modeling in the Deschutes River below Bend or in the Little Deschutes River and Crescent Creek could provide information on the effects of water releases, withdrawals, riparian restoration, and other management actions on stream temperature in the Deschutes River. The modeling effort would also help identify strengths and weaknesses in the current temperature monitoring network in the basin. More intensive efforts, such as Forward Looking Infrared Radiometer (FLIR) data collection, will also be important components to future temperature modeling. Temperature modeling in portions of the middle and upper Deschutes River Basin is projected to occur in 2001 associated with TMDL development (Bonnie Lamb, Oregon Department of Environmental Quality, written commun., 2000).

\subsubsection{Evaluation Monitoring}

\section{Objective: Determine the effects of current management activities on water temperature by:}

Action 17: Considering special studies to evaluate effects on water temperature from surface or ground water withdrawals, floodplain, and riparian development, and restoration projects on stream temperatures.

\subsection{Rationale and Explanation}

Action 17: Consider special studies to evaluate management effects-Water and land use practices in the basin may contribute cumulatively to increased water temperatures, and these effects are therefore likely to be interrelated and difficult to determine individually. Nonetheless, there are opportunities to investigate individual effects in relative isolation so as to better determine their specific contributions to temperature changes. In some cases existing data might be sufficient to address these questions, whereas in others new data might need to be collected. Examples include:

- By explicitly examining existing temperature records before, during, and after periods of streamflow manipulations, or collecting new temperature data, the effects of flow manipulations on temperature in the upper Deschutes River and the middle Deschutes River could be examined.

- A series of overhead flights using remote sensing FLIR technology would provide a spatially continuous snapshot of temperature conditions in selected reaches. These data, in combination with existing temperature recorders and ground truthing in key additional locations, could provide valuable information on spatial changes in water temperatures corresponding to riparian or instream habitat, urbanization and development, agricultural runoff, and water withdrawals and inputs. It could also help identify areas with lower water temperatures that act as critical habitat areas or refugia for salmonids.

\subsection{Turbidity/Sediment Transport}

The concentration and transport of suspended material in streams is an important issue in much of the upper Deschutes River Basin. Several reaches are included on the State's 303(d) list for turbidity, sedimentation, or habitat modification (possibly related to erosion), or are listed as potential concerns for which data are needed to resolve the severity of the problem (fig, 5 , table 2). In reaches downstream from Wickiup Reservoir, erosion of streambanks resulting from flow fluctuations has been identified as a major contributor to sedimentation and turbidity in the rivers as well as to degradation of riparian habitat (USDA Forest Service, 1996b). Few data are available on the erosional status of Crescent Creek, but there is a potential for processes similar to those below Wickiup Dam because the hydrologic 
patterns are altered due to irrigation withdrawals from the lake, and the stream is an alluvial, gravel banked system similar to the upper Deschutes River. Algae in water released from reservoirs during summer can also increase turbidity in the receiving waters. Turbidities that do not meet State standards can be harmful to native fish. Excessive sedimentation or erosion is also known to accelerate channel migration and degrade fish spawning habitat. In general, extremely high flows (flooding) are not a problem in the study area because of flow regulation by the reservoirs and because the large amount ground water input locally stabilizes the hydrograph. However, during low elevation storms, there is potential for increased sediment loading resulting from urban and nonpoint runoff, or inflows from small, ungaged tributaries that are often otherwise dry. These events may contribute disproportionately to elevation of turbidities.

Despite its importance in the basin, previous monitoring for sediment transport has been highly variable among agencies (fig. 5). Many small scale monitoring projects of short durations have been done to estimate effects from individual land management or restoration practices; data from these types of studies are typically difficult to obtain and are of uncertain quality. Among the different organizations monitoring turbidity and sediment, there are several different methods that are being and have been used (principally the use of meters to measure turbidity, or collection of samples for analysis of total suspended solids [TSS] and suspended sediment concentrations). Regional monitoring for suspended material, as suggested in this plan, is oriented to actions that increase the comparability of data and efficiency of collection among agencies, initially fill some apparent data gaps, and address the most pressing resource-management issues related to suspended material.

\subsubsection{Monitoring Objectives and Associated Actions}

In the following sections several interrelated monitoring actions (Actions 20-24) are proposed. For the purposes of this report, the actions are listed separately so that they may be budgeted and scoped separately, however if there are sufficient resources or need they could be undertaken simultaneously for one relatively substantial sediment monitoring project.

\subsubsection{Status, Trends, and Compliance Monitoring}

Objective: Determine spatial (longitudinal) variability, diel and seasonal variability, and long-term trends in suspended sediment concentrations, and

Objective: Determine if suspended sediment (TSS/turbidity) values meet State and Federal water-quality criteria (including TMDL), by:

Action 18: Using TSS as the preferred datacollection protocol, with continuous turbidity monitoring at selected locations;

Action 19: Compiling data bases of existing data and evaluating QA/QC data to determine if enough QA data are being collected, and if data are comparable between sites and agencies;

Action 20: Analyzing existing, usable data to (1) statistically determine optimum sampling frequency and spatial coverage needed to observe changes at a rate specified by management agencies, (2) determine reference (historical) and baseline (current) conditions, (3) look for historical changes over time prior to initiation of new monitoring, and (4) determine relations between TSS and turbidity for existing sites;

Action 21: Establishing periodic sampling for TSS at new locations, such as at OWRD gaging stations on Deschutes River below Wickiup Reservoir and Little Deschutes River at La Pine; and

Action 22: $\quad$ Establishing continuous turbidity monitoring locations, with priority stations in reaches downstream of Wickiup Reservoir. Monitors could 


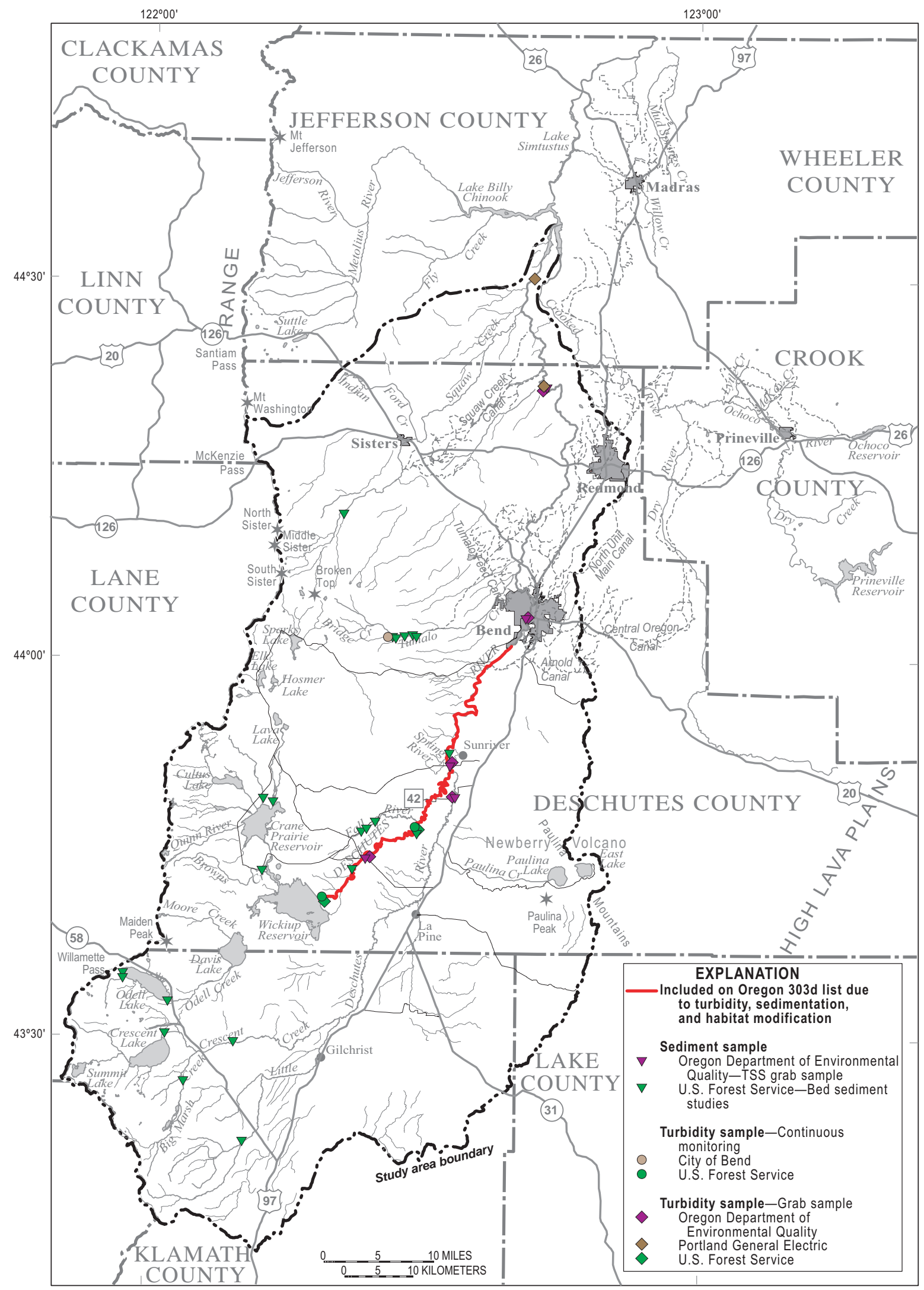

Figure 5. Turbidity, Total Suspended Solids (TSS), and sediment monitoring stations in the middle and upper Deschutes River Basin, Oregon, 1999. 
be located at OWRD gages or at ODEQ ambient monitoring sites.

\subsection{Rationale and Explanation}

\begin{abstract}
Action 18: Establish preferred protocol-The three most common analyses of the amount of particulates in a river sample are suspended-sediment concentration, TSS concentrations, and turbidity. Sampling techniques for each of these are different and measure somewhat different aspects of sediment in water. Suspended sediment is usually collected using techniques that integrate across the depth and width of the stream (Edwards and Glysson, 1999) and the entire sample is analyzed for the mass of sediment; for TSS a simple grab sample is often taken from the stream, with an aliquot from that sample being used to determine the mass of suspended solids; turbidity is an optical measurement of the amount of light scattered caused by particulates in a sample and can be measured with probes either instantaneously or using continuous monitors. Of the three, suspended-sediment concentrations are the most representative and also the most time consuming and expensive measurements, TSS is perhaps the most widely used for sampling water, and turbidity is commonly used for in-place monitoring. TSS has a potential for bias from undersampling of coarse sediment fractions that are likely to be missed in grab samples and in subsequent aliquots (Gray and others, 2000). However, because most agencies that regularly sample in the middle and upper Deschutes River Basin have used TSS in the past and are likely to continue to do so in the future, TSS is suggested as the determination of choice for agencies participating in this plan. Suspended-sediment sampling will likely be warranted in some cases to develop rating curves or for correlations with TSS or turbidity data (see Action 23). Comparison of concurrent samples for suspended sediment and TSS at selected sites, over a range of flow conditions, would also provide valuable quality assurance for interpreting the results of TSS sampling in the basin.
\end{abstract}

Turbidity is important, in part because it is the only measurement of the three for which there is a State standard, but it also is good for continuous monitoring as a relative indicator of changing sediment transport resulting from changing hydrologic or other conditions. Field measurements of turbidity are relatively inexpensive and can provide an effective early screening mechanism on which to base additional sampling or management decisions. The ODEQ provides recommendations to watershed councils on equipment purchasing, calibration, and use, including for field turbidimeters that can be reliable for grab sampling. Relations between turbidity and suspended sediment or TSS can be, and have been, established but they tend to be unique to the specific water bodies or processes being monitored. Establishing strategic locations (Actions 22 and 23) for continuous or spot measurements of turbidity, to be used in conjunction with TSS or suspended-sediment sampling and streamflow data, will help provide long-term data for trend analysis and for developing relationships between turbidity and sediment transport.

\section{Action 19: Compile data base and} evaluate QA/QC data-This task is suggested for turbidity, TSS, and suspended sediment measurements for the same reasons that it has been suggested previously for temperature monitoring (Action 12). These data are collected by a variety of methods, and their comparability among organizations is not necessarily guaranteed. Turbidity, in particular, is subject to bias because of differences in historical instrument design among manufacturers and calibration constraints. Although recent technological changes have improved the reliability of many newer turbidity monitors, as with all monitoring instruments their calibration may drift over time, and calibration standards have until recently been unstable. Turbidity also does not actually measure suspended-solids concentrations but rather the scattering of light. Because so many organizations are collecting turbidity information in the study area (fig. 5), there is a substantial need for an understanding of the reliability and the comparability of these data. An inventory and assessment of quality-assurance data for turbidity monitoring, and for any TSS or suspended sediment monitoring, would provide a basis for knowing which data could reliably be used and analyzed together and which should not. As with 
temperature, it will likely be necessary to gather quality-assurance data for (1) instrument type, age, and specifications, (2) calibration frequency, tolerances, and field records, to evaluate precision and accuracy, (3) miscellaneous check measurements or other applicable grab samples from other organizations that can be used for comparison, and (4) information on the completeness of records, including the amount of missing data. Furthermore, comparisons between TSS, turbidity, and suspended sediment concentrations are warranted to provide a basis for interpretation of turbidity and TSS data. If data are not currently available to make this comparison, it may be necessary to specifically collect samples using two or all three of the methods in order to establish relations between these variables. Finally, the initial task of gathering the turbidity, TSS, and sediment data among organizations is itself likely to be formidable.

\section{Action 20: Analyze existing data-As} with temperature, much data has been collected for sediment-related issues in the study area (fig. 5), not all of which has been analyzed. Analysis of existing data as an initial exercise would help (1) answer the questions the original studies were intended to address, (2) formulate hypotheses regarding water-quality processes, relations between TSS, suspended sediment, and turbidity, and sources of contaminants in the basin, (3) evaluate the value of these data for future monitoring, (4) provide additional evaluation of the quality-assurance practices of collecting organizations, (5) provide data for determination of the status of the resource and baselines for future determinations of trends, and (6) identify data gaps, such as extreme events, in the current monitoring programs in order to make appropriate modifications for future monitoring.

This task could be done without interruption of present routine data-collection programs (mostly by ODEQ but also by the Forest Service). Some relatively straightforward modifications to those programs (for example, Action 21) could be initiated without this more comprehensive analysis of existing data, but decisions about future monitoring will be greatly augmented by the information gleaned from the data analysis process. For instance, some comparison of TSS and turbidity data was done in 1998 for the upper
Deschutes River below Wickiup Reservoir and for the Little Deschutes River (Thomas Walker, USDA Forest Service, Deschutes National Forest, written commun., March 2000). If sound relations for TSS and turbidity can be determined from these comparisons and other existing data (such as ODEQ Ambient Monitoring data) then perhaps additional investigations into this question are unwarranted and monitoring for turbidity and TSS can be redesigned without additional data collection.

\section{Action 21: Establish new TSS} monitoring locations-The ODEQ Ambient Monitoring Network, with five sites in the middle and upper Deschutes River Basin, provides good spatial coverage for routine water sampling and is relatively complete given the patterns of the river network. There are a few important gaps, however, for TSS and turbidity sampling, based on areas of known sediment transport and erosion issues. For example, the ODEQ station on the Deschutes River at Pringle Falls is a useful location for quantifying sediment transport in the upper Deschutes River. However, one of the sediment related issues in this reach is fluctuating turbidity resulting from reservoir operations at Wickiup Reservoir, and proposed sources of turbidity include turbidity released from the reservoir, bank erosion, and bed sediment resuspension in the stream caused by flow fluctuations (USDA Forest Service, 1996b). Routine sampling of TSS at the OWRD gaging station immediately below the reservoir, together with continuous turbidity monitoring, could help establish whether reservoir turbidity itself contributes significantly to sediment transport in the upper Deschutes River. This would be particularly useful in conjunction with increased water sampling in the reservoir (see Action 34). It would also help quantify any additional sediment loads that originate in the reach from Wickiup Reservoir downstream. Additional TSS locations may be identified elsewhere in the basin such as the Little Deschutes River near La Pine, on the basis of known sedimentation issues or resulting from analysis of 
existing data, or in support of management needs (for example, TMDLs).

\section{Action 22: Establish new continuous} turbidity monitors-Although the maintenance and calibration needs of continuous monitors, including those for turbidity, can be substantial, these types of monitors also can provide a tremendous amount of data for relatively little cost. Data can be useful for long-term trend analysis, for evaluating the short-term effects of specific events on water quality, for documenting compliance with standards, to support management needs such as TMDLs, and for understanding the causes of short- and long-term variations in sediment and chemical data. Within the study area, ODEQ's ambient monitoring stations would be useful locations to add continuous monitors for turbidity as well as for temperature, $\mathrm{DO}, \mathrm{pH}$, and specific conductance (see Action 40), because these sites represent most of the major reaches of interest. Establishing continuous monitors, in this case for turbidity, at sites in ODEQ's network (fig. 5) would help increase the consistency of data collection in the region. Alternatively, stream-gaging stations maintained by OWRD would be reasonable locations for continuous monitors because data from these monitors can be related to streamflow and because of the need to house instrumentation, though comparison with ODEQ water-quality data would be less straightforward. As a cost saving measure, monitors could be installed seasonally to account for the most sensitive conditions during which turbidity information are of greatest interest. These conditions could be based on hydrology, during peak flow releases from Wickiup Reservoir in May through July, or on aquatic ecology, during important periods of fish migration or spawning. The highest priority sites would likely be those targeted at turbidity and sediment issues related to releases of water for irrigation from Wickiup Reservoir, specifically (1) Deschutes River at Pringle Falls, (2) Deschutes River at Harper Bridge, and (3) Little Deschutes River at Highway 42. An additional station could be added in other sites such as the Deschutes River at Lower Bridge (ODEQ Ambient Monitoring Network) or Culver (USGS gaging station) if analysis of existing data indicates that data are needed from those locations. Finally, turbidity data from monitors would need to be checked against turbidities or suspended sediment concentrations in entire cross sections of the river to determine the representativeness of monitor data.

\subsubsection{Evaluation Monitoring}

Objective: Determine effects of variations in streamflow from reservoir operations and irrigation withdrawals on downstream sediment concentrations, including daily and seasonal effects, and

Objective: Provide data to develop sediment-discharge rating curves below Wickiup Reservoir, by:

Action 23: Conducting a special study to refine relations between suspended sediment, TSS, and turbidity in upper Deschutes River downstream to Bend and Little Deschutes River; and

Action 24: Conducting a special study to evaluate the relationship between bedload transport and changes in flow and determine sediment sources (reservoir releases, resuspension of bed material, bank erosion) below Wickiup Reservoir to Bend. Include effects of Little Deschutes River on the upper Deschutes River above Bend.

\subsection{Rationale and Explanation}

Action 23: Conduct special study on suspended sediment, TSS, and turbidity relations-From a management standpoint, it would be a great advantage to be able to use a relatively low-cost, continuously monitored constituent such as turbidity as a surrogate for TSS or suspended sediment. Examples of the uses of these data include estimating effects of management practices on sediment concentrations (see Action 24), estimating the load of sediment being transported in a given time period, or quantifying the variability of sediment transport in 
the rivers. Although in principle there are relations between the transport of sediment in the water column and both TSS and turbidity, in practice these relations tend to be specific to individual water bodies and their unique sediment or particulate sources and local hydrological, physical, and biological characteristics. In the upper Deschutes River, releases of water from Wickiup Reservoir have been identified as a cause of bank erosion (USDA Forest Service, 1996), which results in increased sediment transport downstream and sedimentation in the streambed, in addition to destruction of riparian habitat. Fluctuating streamflows also may resuspend streambed sediments, and reservoir releases may contain particulates in the form of phytoplankton algae, especially during summer. All of these source types can produce different types of particulate matter in the water, with the result that the relations between turbidity and suspended sediment or TSS are likely to be different at different times of the year or at different parts of the hydrologic cycle.

In order to decrease the long-term cost of monitoring and increase the value of data collected, it is suggested that a special study be conducted that would determine relations between turbidity and concentrations of suspended sediment and TSS in the upper Deschutes River, over a range of flow conditions. The Forest Service, which is charged with management of the upper Deschutes River, is interested in the use of turbidity monitors and might be willing to take the lead in such an investigation (Randall Gould, U.S. Forest Service, Bend, Oregon, oral commun., 1999). The Little Deschutes River is mentioned for inclusion in this study because it is an important contributor to the flow and sediment regime after it joins the Deschutes River and downstream to the Central Oregon Canal. This action is differentiated from Actions 21 and 22 by its probable short-term duration, and because it would provide data to support the long-term needs of those actions, as well as possible benefits for evaluation monitoring (see Action 24).

\section{Action 24: Special study of sediment} sources and transport-In the upper Deschutes River between Wickiup Reservoir and Bend the amount and specific sources of sediment are an important management issue and remain undefined. In order to best care for the health of the river and its biota while maintaining the ability to supply water for irrigation, it is important to understand the relationship between flow, flow changes, seasonality of flow releases (including extreme events), and bedload or sediment transport. It would also be helpful to determine the relative importance of sediment sources, such as water from the reservoir, bank erosion below the reservoir, recreation and other activities along the river and tributaries, and resuspension of bed material, from Wickiup Reservoir to Bend. Such a study would most likely rely, in part, on implementation of other aspects of the monitoring plan, including analysis of previously collected data (Action 20), TSS/turbidity monitoring (Actions 21 and 22), information on the relations between turbidity, TSS, and suspended sediment (Action 23), and studies of channel morphology in the same reaches (Actions 27-30). Hence it would be best attempted after those actions have been initiated. Actions 23 and 24 could both be important in the development of TMDLs for sedimentation and turbidity.

\subsection{Physical Channel M orphology/ Aquatic Habitat}

There are many issues associated with the adequacy of, and changes in, the physical structure and functioning of streams (morphology) and the quality of aquatic habitat in the study area. These issues are often related to questions of suspended material in streams (section 3.4). The State has included several river reaches on the 303(d) list for habitat modification (table 2), the criteria for which include (1) low multimetric or multivariate biological ratings for macroinvertebrate communities, (2) low ratings for indices of biological integrity, or (3) a combination of poor or declining fish populations and habitat conditions that limit fish production (Oregon Department of Environmental Quality, 1999c). Reservoir operations and their downstream effects are considered to be causes of much of the changes in stream morphology (Cameron and Major, 1987; USDA Forest Service, 1996b), but other potential causes include extreme flooding (infrequent, but potentially important in some locations), forest-management practices such as timber harvesting and road building, recreational uses of stream and riparian areas, agricultural practices (generally irrigation 
withdrawals or livestock grazing) and commercial or private development along riparian areas.

Perhaps more than any other "water-quality" related issue included in this plan, past projects to measure the status of channel morphology and habitat have been done by many different organizations with a wide variety of methods, some more quantitative and (or) objective than others (Roper and Scarnecchia, 1995; Bauer and Ralph, 1999). Agencies involved in these measurements have included the Forest Service, the BLM, the USGS, the Oregon Department of Fish and Wildlife, the Oregon Department of Environmental Quality, and Portland General Electric, with the Forest Service being the most active recently (fig. 5). The State of Oregon also is monitoring and restoring salmon habitat on a statewide basis through the Oregon Plan for Salmon and Watersheds (State of Oregon, 1997). Most of these organizations have had their own protocols in use, or have had different protocols among individual offices, during different time frames, or for specific project purposes. Therefore, as with other aspects of the monitoring plan, many of the monitoring actions suggested herein are directed towards bridging the differences in monitoring efforts among organizations in order to increase the overall efficiency of those efforts and provide a common basis for comparison. Additional actions to help establish baseline conditions, to evaluate changes over time, and to evaluate effects of specific land and watermanagement practices are suggested. Note that, because there are no standards or criteria for stream habitat and channel morphology, there are no objectives or actions targeted towards compliance monitoring.

\subsubsection{Monitoring Objectives and Associated Actions}

\subsubsection{Status and Trends Monitoring}

\section{Objective: Establish baseline conditions and evaluate changes over space and time, by:}

Action 25: Compiling a database of existing data among agencies, including metadata, to evaluate usability of data currently available and to determine what locations have or have not been studied;

Action 26: Analyzing existing, usable data to (1) determine optimum sampling frequency and spatial coverage to observe a rate of change that is agreed upon by water management agencies in the basin (2) determine reference [historical] and [or] baseline [current] conditions, and (3) look for changes over time prior to initiation of new monitoring;

Action 27: Conducting monitoring at subbasin and "indicator" reach scales, as follows:

-At the subbasin scale, use remote sensing (aerial photography) and GIS to document sinuosity, riparian vegetation, areal extent of wetlands, and amount of development within the floodplain, repeated every 5-10 years.

-At the "indicator" reach scale, use selected attributes from IRICC protocols (IRICC Fish Hydrography Strike Team, 1999) and methods by Harrellson and others (1996) to document channel geometry and habitat characteristics, repeated every $2-5$ years (or following major flood events) at each site.

Action 28: Consider special studies to establish baselines for areas that have not yet been surveyed, especially any critical stream segments of the upper Deschutes River, Little Deschutes River, Squaw Creek, and Tumalo Creek.

\subsection{Rationale and Explanation}

Action 25: Establish database of existing data-Many studies of stream morphology and aquatic habitat have been done in reaches of the upper Deschutes River and its 
tributaries, yet little of those data are readily available. A preliminary analysis of bed-sediment distribution, erosion, and transport was done in late 1980's (Cameron and Major, 1987), and an analysis of historical channel changes was initiated as part of an Instream Flow Assessment done in 1994 (USDA Forest Service, 1994); however, for most of the major reaches addressed by this monitoring plan, there is no consensus on historical reference conditions or even current (baseline) conditions. As for many of the other issues addressed in this plan, an important first step in the assessment of current and past conditions will be to assemble data from the various sources and make a determination of their use for analysis in conjunction with other datasets. Metadata refers to information about the dataset itself, including protocols used, dates and locations sampled, objectives of study, and other information that can be used to determine the applicability and content of existing data. For geomorphic and habitat studies, QA/QC data may be less applicable or available, so metadata could be the only information to use to determine whether a study's data will be usable in conjunction with other datasets. Pertinent questions that could be asked about the data include: What were the objectives of the study? What is the database structure and accessibility of the data? Were the protocols used published and commonly used by other agencies in the region? Are the measured parameters objectively defined and repeatable? Do the datasets include basic information such as dates, locations, and estimates of discharge?

The Forest Service is currently in the process of compiling data from most of its previous stream studies, including stream habitat and morphology data, into a common, national database, termed NRIS (National Resource Inventory System). This process is expected to greatly simplify tasks such as Action 25. The NRIS database will not, however, include data collected by agencies other than the Forest Service. Likewise, the BLM is creating a database called ARIMS (Aquatic Resources Information Management System), although this system is still several years from being operational. The task of assembling an overall dataset for geomorphic and habitat data in the basin is itself likely to be substantial; therefore it is included here as a separate action from data analysis.

Action 26: Analyze existing data-Once a reliable dataset has been assembled as indicated above, an analysis of those data is suggested, with the objectives being to (1) define baseline conditions where possible and (2) use the results to modify future sampling strategies, including defining which data are the most useful and are critical to collect, and obtaining estimates of variability to use in determining statistical power and sampling frequencies. Additionally, such an analysis would help refine current conceptual understandings of the important channel processes in the reaches of interest. The reaches of highest priority for this analysis would be those most affected by flow changes or where biological considerations are the most pressing. In particular, these reaches would likely include the upper Deschutes River from Wickiup Reservoir to the Little Deschutes River, the Little Deschutes River itself, the upper Deschutes River from the Little Deschutes River to Bend, which are all affected by reservoir releases. Also, the middle Deschutes River from Bend to Lake Billy Chinook, the flow of which is severely altered by irrigation withdrawals, would be included. Squaw Creek, which is included on the 303(d) list for habitat modification, would also be a candidate for analysis.

\section{Action 27: Conduct monitoring at} multiple scales-At a relatively large scale (for example, subbasin scale), it is possible to measure a number of important stream parameters using aerial photography or other remote methods. These measurements could be made at relatively little expense, probably through the use of a GIS system, and would serve to classify changes along the length of selected study reaches. At smaller scales, measurements can be taken with teams in the field, using previously defined indicator reaches, to document more intensively the local stream physical structure and habitat conditions in relatively short sections of river. Because habitat measurements tend to be highly subjective (Roper and Scarnecchia, 1995), this plan focuses more on the most repeatable, physical measurements of stream geometry. The indicator reach monitoring 
would be done more frequently, on the order of once every $2-5$ years or more for each study reach, and, if possible, immediately following flood events with recurrence intervals of 25 or more years.

Specific determinations made from remotely sensed data at the subbasin scale would include sinuosity (the channel length divided by the river valley length); the number and length of oxbows and side channels; amount, type, and extent of wetlands and riparian vegetation (trees, shrubs, and herbaceous plants); and possibly the extent of floodplain development. Estimates of floodplain development, which could include measurements of road densities, impervious area, numbers of structures, and population within the floodplain, might be best undertaken initially with leadership from State programs or academia. Part of a relatively complex model for this type of analysis was recently published for the Willamette River Basin by a consortium of researchers from the University of Oregon, Oregon State University, the USEPA, the Forest Service, and others (Pacific Northwest Ecosystem Research Consortium, 1998); however, that report contains much more land-use information for the Willamette Basin than is proposed here for the Deschutes, and it is not oriented specifically towards the river's floodplain but rather the entire river basin. Nonetheless, it provides an example of the types of information that could be useful in describing and tracking development along river corridors in the middle and upper Deschutes River Basin. Useful information might also be available through the National Wetlands Inventory database, the Oregon Division of State Lands, or county and city planning departments.

Specific determinations for the indicator reaches would be done in the field using published methods acceptable to the respective agencies, such as the Forest Service, the BLM, and the Oregon Department of Fish and Wildlife. These would primarily be measures of physical stream attributes; however, some of the more repeatable and widely used habitat measurements would be included as well. The stream attributes listed under the IRICC protocols (IRICC Fish Hydrography Strike Team, 1999), which are being adopted by the BLM and the Forest Service, are appropriate for this type of analysis. They include determinations of cross-sectional area, width-to depth ratio, wetted perimeter, longitudinal profile (gradient), bankfull width and depth, and a measure of overall streambed material such as pebble counts. Specific locations (cross sections, pools, and riffles) within reaches would be selected and flagged for repeat measurements of the physical attributes over time with exact coordinates recorded by a global positioning system (GPS). Also included would be measurements of stream patterns (meander length, belt width, and radius of curvature) that are easily determined from aerial photography but which are most properly applicable to the smaller scale of the indicator reaches as described here. Field methods for measurement of most of these attributes are well described in a commonly used manual by Harrelson and others (1994).

Additional habitat measurements at each indicator reach would include the abundance of large woody debris (LWD) and pool frequency. Streamflow measurements would also be made as part of each site visit to the indicator reaches.

Stream systems can be highly variable in time, and measurements of stream indicator reaches are likely to reflect this variability. Many repeated measurements, over decadal time frames and a broad range of hydrologic conditions, may be necessary to detect statistically and environmentally significant changes. This time may be shortened somewhat if analysis of existing data allows baseline conditions to be established in some locations for previous years (that is, "hindcasting") or if selected critical reaches are measured more frequently.

The indicator reach measurements outlined above are not intended to replace the regular Stream Surveys conducted by the Forest Service. Those surveys, which use protocols established by Hankin and Reeves (1988), remain important for the Forest Service and it is assumed that they will continue to be done in the basin. Data collection for the indicator reaches as outlined here would be done in addition to the stream surveys, or perhaps at the same time if at all possible because much of the same data are used for both protocols.

Likewise, the approaches suggested for this plan are intended to be compatible with the recommendations contained in the Oregon Plan 
(State of Oregon, 1997), which are fairly general in nature.

Owing to the importance of flow releases from Wickiup Reservoir and Crescent Lake, and their roles as sources of irrigation water, causes of geomorphic channel changes, and management issues, the primary river reaches to be addressed with the above techniques would be (1) upper Deschutes River from Wickiup to Little Deschutes River, (2) upper Deschutes River from Little Deschutes River to Bend, and, possibly, (3) the Little Deschutes River including Crescent Creek. Specific study subreaches would be selected from these larger reaches, representing not only federally owned but State and private lands as well. Additional study will be important in the other reaches specified in the study area, and could include the middle Deschutes River between Bend and Lake Billy Chinook, Squaw Creek, and Tumalo Creek, as resources allow. Final decisions on specific study subreaches would be made by agency scientists in consultation with those coordinating the regional monitoring plan.

\section{Action 28: Establish baselines for} undocumented reaches-Some of the reaches that may be chosen for monitoring at the subbasin or indicator reach scales, as indicated above, may not have been studied in the past. In these cases, baselines will be established the first time that they are surveyed. However, it may be possible, through a qualitative analysis of historical records or specific field surveys, to develop a conceptual understanding of probable baselines or physical processes prior to current conditions. The types of historical information that could prove useful would include accounts of explorers, early maps, or surveys conducted during railroad expansion. Quantitative habitat assessments or fisheries surveys prior to dam construction are unlikely to be found but nonetheless may exist for certain locations. Locally specific field investigations, including evaluation of flood deposits, stratigraphic records, or streambed morphology could be undertaken to estimate the relative importance of various processes (for example floods, landslides, volcanic eruptions, or woody debris) in channel formation and migration. In selected reaches that are important from a scientific or management standpoint, such studies might provide a perspective from which to understand the river systems, extrapolate the potential effects of flow manipulations, or gain insights about the extent to which the systems can realistically be restored.

\subsubsection{Evaluation Monitoring}

As indicated, maintaining channel integrity and habitat quality is one of the most common water-management goals in the upper Deschutes River Basin. These aspects have been and will continue to be affected by land and water-use practices. Making decisions on future land and water use will be facilitated if agreement can be reached on fundamental questions such as what the current processes are that affect the river's geomorphological and habitat structure, and whether those processes are substantially different from the dominant processes prior to construction of the reservoirs. Several monitoring actions are oriented towards tracking changes in the river system resulting from these processes (Actions 17, $21,22,24,26,27$, and 28); however, an understanding of the processes involved, and of the degree to which the rivers have already been changed, will likely require more detailed geomorphic analysis of the system than monitoring alone is likely to provide. The following special studies are suggested in order to help answer pervasive questions about (1) changes that have taken place since the reservoirs became operational and significant amounts of water were diverted for irrigation and (2) current effects of those management practices on the rivers. These studies would ultimately allow managers to more completely evaluate potential changes in management practices for their effects on stream morphology and habitat.

\section{Objective: Evaluate effects of reservoir operations, flow management, and other land uses on channel morphology, habitat, and riparian vegetation, by:}

Action 29: Considering special studies to evaluate changes in historical streambed morphology after construction of reservoirs; and

Action 30: Considering special studies in selected reaches (for example, 
upper Deschutes River below

Wickiup Reservoir, Deschutes

River from Bend to Lake Billy

Chinook) to evaluate the effects of

short-term fluctuations and seasonal

flow modifications on:

-Stream physical environments

(channel morphology, bank

stability, etc.),

-Water quality, including turbidity, stream temperature, and water chemistry; and

-Stream ecology, including

invertebrate populations, fish

habitat, fish populations, macrophyte or other aquatic plant growth.

\subsection{Rationale and Explanation}

\section{Action 29: Evaluate historical changes-}

A study to reconstruct historical geomorphic change, prior to and after construction of dams, would help improve the understanding of the relative effects of Wickiup Reservoir and Crescent Lake operations on the upper Deschutes River and the Crescent Creek/Little Deschutes River systems, respectively. Of particular interest would be the degree of natural variability historically, possibly resulting from periodic flooding or other extreme events, in comparison to the variability in stream geometry under current conditions. Some work has already been done along these lines by Cameron and Major (1987) and during various instream flow assessments (USDA Forest Service, 1994; USDA Forest Service, 1996b), although these have not been comprehensive assessments. One finding was that the river below Wickiup Reservoir is still adjusting to the new flow regime imposed on it by reservoir releases after construction of Wickiup Dam from 1939-49. For example, during the 1994 study, the river was found to be 20 percent wider and to have formed a disproportionately high number of cutoff meanders since 1943 in response to reservoir releases, with higher peak flows and shifted hydrologic patterns, and to removal of large woody debris (USDA Forest Service, 1994). It is likely that additional changes have occurred since the 1994 study as the river continues to adjust. It would be useful to know if the river's morphology still is truly in transition or has reached some sort of equilibrium set of channel processes. It would also be advantageous to understand the causes and consequences of bank erosion problems, and if possible to get an idea of the expected rate or magnitude of change, or the expected habitat conditions, that would result from different flowrelease options and other management scenarios.

This study of the upper Deschutes River could involve (1) the use of historical and current maps to define the expected variability in stream channels, (2) field measurements of current channel configurations and searches for physical evidence of previous channel migration, and evaluations of the relative importance of reservoir operations, or (3) evaluation of tributary inputs, and large hydrologic events in determining historical channel morphology.

A similar study could be proposed for the middle Deschutes River, from Bend to Steelhead Falls or further, where irrigation withdrawals reduce spring and summer streamflow to a fraction of its historical flows. However, this reach is largely constrained by its bedrock channel in a canyon, so habitat problems in the reach may be more related to low flow, temperature increases, or nonnative species than to physical channel changes.

Action 30: Evaluate current effects of flow modifications-This study is proposed as a followup to the above evaluation of historical geomorphic processes in the upper Deschutes River (Action 29). In this phase of the study, the current effects of management practices, including reservoir operations and water withdrawals, would be evaluated with respect to their effects on channel morphology, sediment transport (see Action 24), and aquatic habitat. The principal study reaches would be, as indicated earlier, the upper Deschutes River from Wickiup Reservoir to the Little Deschutes River and downstream to Bend, and Crescent Creek and the Little Deschutes River. The middle Deschutes River from Bend to Steelhead Falls could also be evaluated, either separately or in conjunction with the upstream reaches, for its effects from water withdrawals. 


\subsection{Nutrients}

The OWQI, updated by the Oregon Department of Environmental Quality through 1999 for Ambient Monitoring sites in the study area, indicates generally good to excellent water quality in the basin. There was an overall increasing (improving) trend at the Harper Bridge (Sunriver) and Mirror Pond (Bend) sites, and no trend at the Lower Bridge site (Curtis Cude, Oregon Department of Environmental Quality, written commun., 1999). Despite these positive signs, there is evidence that several of the major reaches included in the study area have seasonal problems with eutrophication. The middle Deschutes River from the North Unit Canal to Lake Billy Chinook and the Little Deschutes River are included on the 303(d) list for parameters such as low dissolved-oxygen concentration or high $\mathrm{pH}$ (table 2), which are commonly associated with algal blooms resulting from excessive nutrient loading. Such results might not be represented by the OWQI if Ambient Monitoring data are collected at these sites without regard to diel variation. The Little Deschutes River is also a candidate for the 303(d) list because of concerns with nutrients (Oregon Department of Environmental Quality, 1999a). There are occasional high spikes in phosphorus concentrations, and generally high biochemical oxygen demand (BOD), at the Harper Bridge site- the reasons for these excursions are not known. High phosphorus and BOD concentrations are also noted at Mirror Pond, and increasingly higher phosphorus concentrations, with high $\mathrm{pH}$, are observed farther downstream at the Lower Bridge site (Oregon Department of Environmental Quality, 1999d).

There are potential nutrient sources in the basin about which little is known. These include lakes and reservoirs managed by the Bureau of Reclamation, high nitrate-nitrogen concentrations in shallow ground water in the La Pine area that could act as a nutrient source to the alluvial Little Deschutes River, urban runoff in Bend or Redmond, and a variety of agricultural activities. Although there are few permitted point sources contributing waste directly to the rivers, septic systems or landscape fertilization associated with the numerous private homes along the rivers could act as nonpoint sources of nutrients. Investigations of some or all of these sources would provide valuable information for management of waterquality problems associated with eutrophication.

There is a small amount of ongoing nutrient monitoring in the basin, but it is not currently coordinated among agencies or oriented towards any common objectives. Nutrient data have been collected as part of the ODEQ's Ambient Monitoring Program for many years, but are not otherwise routinely collected in the basin's streams by any other organizations (fig. 6, table 3 ). The Bureau of Reclamation intends to collect water samples, including those for nutrients, at one or two sites in each reservoir once every $3-5$ years, although recent sampling has been less frequent. Monitoring objectives and actions listed here are similar to those for other topics, and are primarily intended to help improve coordination and utility of current activities. Additional suggestions are made to increase the frequency of sample collection in some instances in order to help define the magnitude and variability of nutrient loading from individual sources, and special studies are suggested to help determine the importance of several possible nutrient sources.

\subsubsection{Monitoring Objectives and Associated Actions}

\subsubsection{Status, Trends, and Compliance Monitoring}

\section{Objective: Determine spatial (longitudinal) and seasonal variability, and long-term trends, in nutrient concentrations in streams, and}

Objective: Determine if nutrient concentrations meet State or Federal water-quality criteria (including TMDLs), by:

Action 31: Compiling existing data and evaluating QA/QC data to determine if enough QA data are being collected and if data are comparable between sites and agencies; 


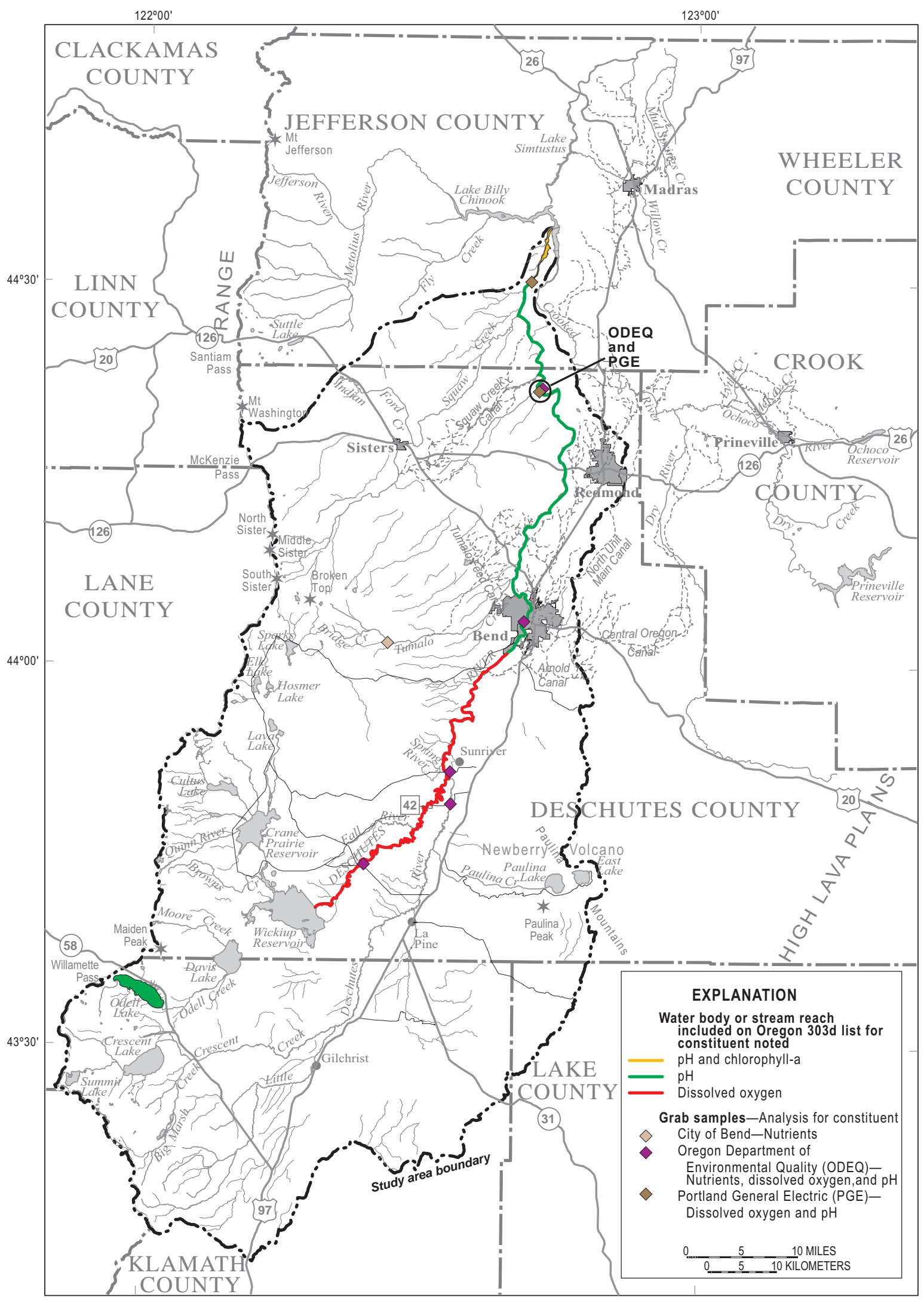

Figure 6. Nutrient, DO, and pH monitoring stations in the middle and upper Deschutes River Basin, Oregon, 1999. 
Action 32: Analyzing existing data to determine baseline conditions and look for changes over time;

Action 33: Using ODEQ's sample collection, preservation, and analytical protocols as preferred nutrient protocols for monitoring;

Action 34: Increasing frequency of sampling in Wickiup Reservoir and Crescent Lake to provide additional information on nutrient transport and loading to the upper Deschutes River; and

Action 35: Follow USEPA Region 10's effort to determine regional nutrient criteria for streams.

\subsection{Rationale and Explanation}

Action 31: Compile existing data and evaluate QA/QC data-As with temperature and other water-quality constituents in this plan, an analysis of existing data would be an important step in the final design of a new monitoring network for the basin. The first phase of that process would be to gather and analyze information on the quality of the existing data. Important data quality elements to look for would include those mentioned previously and listed in Appendix B (such as bias, variability, and accuracy), as well as any evidence of sample contamination, and a listing of the field and analytical methods used and the detection levels achieved. Although nutrients are commonly analyzed by many laboratories, there are numerous methods that may not be directly comparable and terminologies that can be easily confused. Where multiple detection levels have been used among different data sources for the same constituents, this exercise could indicate what subsets of data can be analyzed together and what subsets might need to be ignored.

Comparison of analytical methods would include consideration of sample filtration and preservation techniques.

Action 32: Analyze existing data-After completion of data gathering and analysis of quality-assurance information as indicated above, the environmental nutrient data themselves would be analyzed. Specifically, the types of analysis suggested include:

- Statistical refinement of the sampling network to more accurately determine the number of samples needed at each location, in order to detect desired changes over time, by using information on analytical, seasonal and spatial variability of nutrient concentrations.

- Adequacy of current detection levels for nutrients: lower detection levels may be necessary to detect trends for some constituents if nondetections are prevalent in datasets.

- Investigation of sources and processes by evaluating relations of nutrient concentrations with streamflow, TSS concentrations (or turbidity), indicators of stream productivity (algal biomass, diel $\mathrm{pH}$ or dissolved oxygen cycles), or other constituents, and by evaluating concentrations and speciation of nutrients at given locations, times of year, or flow conditions.

- Definition of baseline concentrations. Information on variability could be used to help define a range of concentrations typical of baseline conditions.

- Compliance with State or Federal Standards or evaluation of trophic state.

\section{Action 33: Establish preferred} protocols-In order for water-quality data collected by multiple organizations to be comparable and usable in combined datasets, it is important that the methods used be as similar as possible. In the case of nutrients, the primary opportunities for differences have to do with field processing, preservation and handling, laboratory analysis, and nomenclature. Because the organization collecting most nutrient data in the basin is the Oregon Department of Environmental Quality, through the Ambient Monitoring Program and miscellaneous studies, their protocols are suggested as the preferred protocols (table 5). The only other routine nutrient collection that occurs in the basin is the infrequent (once every 3-5 years) reservoir sampling done by the Bureau of Reclamation. With respect to nutrients, methods for field processing and analysis used by the 
Bureau of Reclamation are essentially identical to those in table 5. Additional nutrient species that could prove valuable in understanding system processing, including transport of nutrients from the reservoir systems to downstream reaches, are the dissolved, organic forms of phosphorus and nitrogen. These nutrients have been shown to represent not only a large portion of nutrient budgets in northwest streams (Triska and others, 1984) but also an additional pool of bioavailable nutrients (Paerl and Downs, 1978; Tuchman, 1996), especially below reservoirs (for example, see Anderson and Carpenter, 1988). Thus, if sufficient funds are available, addition of dissolved-organic nitrogen (that is, filtered, Kjeldahl nitrogen) and total-dissolved phosphorus (filtered, digested phosphorus) would be useful additions to the suite of nutrients sampled.

\section{Action 34: Increase reservoir sampling}

frequency-Management of water quality in the lakes and reservoirs of the upper Deschutes River Basin is integral to management of water quality in the rivers themselves. Despite substantial ground water inputs from the Fall River and Spring River, and other locations, most of the water that enters the upper Deschutes and Little Deschutes Rivers passes through either the Wickiup/Crane Prairie Reservoir complex or Crescent Lake. Water quality in these large water bodies, therefore, strongly influences waterquality conditions entering the rivers, and to a large extent these conditions will be propagated downstream before being modified by other inputs or instream processes. If the lakes and reservoirs become progressively more eutrophic over time, export of nutrients or algae-caused turbidity is likely to increase, resulting in negative effects on water quality in the downstream reaches. Many of the possible management strategies for the upper Deschutes River revolve around different options for releasing water from Wickiup Reservoir, and it is important that water-quality conditions and processes in the reservoir be understood in order to anticipate potential in-lake and downstream effects of different flow-release options.

The ODEQ collected data on the reservoirs in the mid-1980's but has not revisited them since that time. The Forest Service collected water samples for a standard suite of analyses (nutrients, major ions, algae and zooplankton, and made field measurements) from Wickiup Reservoir in 1991 and 1997. Routine monitoring is planned by the BOR on Wickiup and Crane Prairie Reservoirs, Crescent Lake, and Haystack Reservoir, but at a very low measurement frequency. The current program plans for sampling approximately once every 3-5 years, although Wickiup Reservoir was last sampled in 1995 and Crescent Lake in 1991 (unpublished STORET data; Norbert Cannon, Bureau of Reclamation, oral commun., 2000). The next samplings are scheduled for the summer of 2001. This is typically not frequent enough to be able to document the status or trends for systems as dynamic as lakes, especially if periodic algae blooms occur in those lakes between samplings. Nor does it provide enough information to determine nutrient loading to downstream reaches from the reservoirs or meet most of the other needs identified above.

As an example, Crescent Lake was characterized in 1985 as having excellent water quality and as being "distinctly oligotrophic," but with the possibility of adverse effects from human activities, on the basis of three summertime samplings between 1981 and 1982 (Johnson and others, 1985). Yet in a sampling from August 1991, $\mathrm{pH}$ in the lake's hypolimnion ranged from 8.9 to 9.5, well in excess of the State's upper allowable $\mathrm{pH}$ limit of 8.5. Hypolimnetic DO readings exceeding 120 percent of saturation support the inference that a strong algal bloom had occurred, indicating possible degradation of water quality in this previously oligotrophic lake. No other data have been collected since 1991 so the current trophic status of Crescent Lake is unclear. It is entirely possible that other blooms may have occurred that were not sampled. Likewise Wickiup Reservoir, a shallow lake that was classified as mesotrophic but with abnormally high phosphorus concentrations in 1982 (Johnson and others, 1985), is susceptible to increased eutrophication, particularly with eutrophic Crane Prairie Reservoir upstream. Algal blooms in the reservoir are known to supply part of the turbidity to the upper Deschutes River downstream. Yet with the most recent sampling having occurred there as long ago as 1995, there is little knowledge of the recent water quality in the reservoir. 
Table 5. Laboratory and field methods for sampling, preservation, and analysis of nutrients in water samples used by the Oregon Department of Environmental Quality in the Ambient Monitoring Program

[Method numbers are U.S. Environmental Protection Agency Method Numbers except for total phosphorus, which is a method included in Standard Methods (American Public Health Association, 1985). Source: Oregon Department of Environmental Quality, 1994; $\mu \mathrm{m}$, micrometer; $\mathrm{mg} / \mathrm{L}$, milligrams per liter]

\begin{tabular}{|c|c|c|c|c|c|}
\hline Constituent & $\begin{array}{l}\text { STORET } \\
\text { code }\end{array}$ & Method number & $\begin{array}{l}\text { Field filtration } \\
\qquad(0.45 \mu \mathrm{m})\end{array}$ & Preservation & $\begin{array}{l}\text { Detection limit } \\
(\mathrm{mg} / \mathrm{L})\end{array}$ \\
\hline $\begin{array}{l}\text { Nitrite, Dissolved, } \\
\mathrm{mg} / \mathrm{L} \text { as } \mathrm{N}\end{array}$ & 00613 & 353.2 & $\mathrm{No}^{\mathrm{a}}$ & $\begin{array}{c}\text { Chill at } \\
4 \text { degrees } \\
\text { Celsius }\end{array}$ & 0.02 \\
\hline $\begin{array}{l}\text { Nitrate + Nitrite, } \\
\text { Dissolved, mg/L as N }\end{array}$ & 00631 & 353.2 & $\mathrm{No}^{\mathrm{a}}$ & $\mathrm{H}_{2} \mathrm{SO}_{4}$ & .02 \\
\hline $\begin{array}{l}\text { Ammonium, Dissolved, } \\
\mathrm{mg} / \mathrm{L} \text { as } \mathrm{N}\end{array}$ & 00610 & 350.1 & $\mathrm{No}^{\mathrm{a}}$ & $\mathrm{H}_{2} \mathrm{SO}_{4}$ & .02 \\
\hline $\begin{array}{l}\text { Total Kjeldahl Nitrogen, } \\
\mathrm{mg} / \mathrm{L} \text { as } \mathrm{N}\end{array}$ & 00625 & 351.2 & No & $\mathrm{H}_{2} \mathrm{SO}_{4}$ & .2 \\
\hline $\begin{array}{l}\text { Orthophosphorus, } \\
\text { Dissolved, mg/L as P }\end{array}$ & 00671 & 365.2 & Yes & $\begin{array}{c}\text { Chill at } \\
4 \text { degrees } \\
\text { Celsius }\end{array}$ & .005 \\
\hline $\begin{array}{l}\text { Phosphorus, Total, } \\
\mathrm{mg} / \mathrm{L} \text { as } \mathrm{P}\end{array}$ & 00665 & $424 \mathrm{~F}$ & No & $\mathrm{H}_{2} \mathrm{SO}_{4}$ & .01 \\
\hline
\end{tabular}

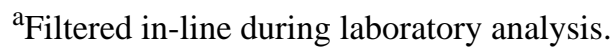

Without more current information, it is unknown what threat Crescent Lake and Wickiup Reservoir pose to water quality in Crescent Creek, the Little Deschutes River, or the upper Deschutes River.

The suggested frequency of sampling is once each winter and monthly during the springsummer season (May-October), although a minimum frequency would be twice each summer and once in the winter. Sampling for field parameters (temperature, dissolved oxygen, $\mathrm{pH}$, and specific conductance) would include a vertical water column profile from at least five depths (surface, mid-epilimnion, metalimnion, upper hypolimnion, and bottom) in the stratified lakes and two to three depths in the shallow lakes. Sampling for water chemistry would include the same general suite of parameters sampled currently, from at least three depths (midepilimnion, metalimnion, and mid-hypolimnion) plus an additional sample from the lake's withdrawal depth if different from the other three depths sampled. In-lake locations sampled would be the same as historically (near the dams) to estimate concentrations entering streams, although additional sampling at up-reservoir sites would help determine the variability of nutrient concentrations or the extent of algal blooms.

\section{Action 35: Follow USEPA Regional Nutrient Criteria development-Currently} there are few or no nutrient criteria for freshwater. There is a drinking water standard for nitratenitrogen $(10 \mathrm{mg} / \mathrm{L}$ [milligrams per liter]) that is intended for protection of human health, and there are standards to protect against toxicity from un-ionized ammonia in water; however, neither of these standards is oriented towards preventing ecological degradation. Environmentally relevant concentrations for nitrogen and phosphorus are much lower than these, typically less than $0.7 \mathrm{mg} / \mathrm{L}$ for total nitrogen and $0.05 \mathrm{mg} / \mathrm{L}$ for total phosphorus in streams (Bothwell, 1992; Dodds and others, 1997; U.S. Environmental Protection Agency, 2000). The USEPA has developed guidelines to help States set nutrient criteria for streams and lakes, on an ecoregion basis, to limit eutrophication and minimize nuisance-algal 
conditions. Provisions are made for waterbodyspecific criteria to be set where sufficient data exist. Although the process of setting criteria by States may ultimately take several more years, the resulting nutrient concentrations could be considerably lower than are currently allowed in some locations. Such an outcome could affect TMDL development, regulation of certain discharges, listings of individual streams as waterquality limited, and land use along river corridors or in some watersheds. There is little that can or should be done to make operational changes in water management in anticipation of these criteria. However, development of a sound database on nutrients and eutrophication, including reasonable estimates of reference conditions, would help make a case for criteria that are specifically tailored to the geology, hydrology, and ecology of the basin. Development of these criteria nationally can be followed on the Environmental Protection Agency's web page at http://www.epa.gov/ ostwater/standards/nutrient.html.

\subsubsection{Evaluation M onitoring}

Nutrient concentrations in streams are related to many different physical, biological, and land-management aspects of the watersheds, and indeed many of the water-quality management issues in the middle and upper Deschutes River Basin are related at least indirectly to nutrients. Evaluation of several of these issues could include consideration of their effects on nutrients, and subsequently on aquatic ecosystems, and would be applicable to such tasks as developing TMDLs or nutrient criteria. Several special studies are briefly outlined below that could be used to determine the effects of some of the more prominent waterquality management issues in the basin. As with evaluation monitoring in other portions of this report, these studies would require more thorough scoping if they are to be undertaken.

\section{Objective: Determine sources of elevated nutrient concentrations, and their effects on trophic status in selected reaches where eutrophication is indicated, and}

Objective: Determine effects of selected management activities on nutrient concentrations in streams, by:

Action 36: Conducting special studies to evaluate:

-Status of nutrient limitation, if any, by nitrogen or phosphorus in key stream reaches and during key seasons;

-Relation of nutrients to discharge, high $\mathrm{pH}$, low dissolved-oxygen concentration, algal abundance, and nutrient sources in the middle Deschutes River, to support TMDL development;

-Effects of urban and riparian development, and high flow events, on nutrient concentrations and water quality;

-Effects of different management alternatives on reservoir and downstream water quality;

-Quantity and quality of irrigation return flow to Deschutes River between Bend and Lake Billy Chinook;

-Ground-water inputs in area of La Pine and other suspected gaining reaches, and their effects on water quality; and

Action 37: Determining historical changes in reservoir water quality since construction by examination of algal records and geochemistry in lake sediments.

\subsection{Rationale and Explanation}

Action 36: Conduct special studiesMost of the special studies suggested here are related and could be conducted with somewhat similar approaches. Nutrient concentrations and ancillary information (discharge, temperature, specific conductance, $\mathrm{pH}$, dissolved oxygen, and alkalinity) would be analyzed above, below, and including suspected sources (including key tributaries, and possibly including high and low 
flows). In some cases there could be great advantage to the use of naturally occurring stable isotopes of nitrogen, carbon, or oxygen in determining sources or pathways of nutrients. Several of the suggested studies are described in more detail below.

Nutrients in the middle Deschutes-The ODEQ Water Quality Index indicates that water quality in the reach from Bend to Lake Billy Chinook is the poorest in the study area. The 303(d) listing for $\mathrm{pH}$ and temperature in this reach is an indication that algal abundance could be approaching nuisance levels in the middle Deschutes River. The metabolic cycles (photosynthesis and respiration) of benthic algal growth can cause diel variations in $\mathrm{DO}$ and $\mathrm{pH}$. Under natural conditions these cycles are moderate, and DO may respond more to physical processes such as reaeration and temperature cycling than to biological processes (for example, see Anderson and Carpenter, 1998, or Guasch and others, 1998). However, when algal growth becomes excessive these cycles are unusually strong, with maximum concentrations occurring in the evening and minimum concentrations in the morning, often causing conditions that do not meet State water-quality standards. Extreme examples of this phenomenon have been observed in many other Oregon streams with disturbances of the natural nutrient and flow regimes, including the Grande Rhonde River (Oregon Department of Environmental Quality, 2000a), South Umpqua River Basin, (Tanner and Anderson, 1996), Coast Fork Willamette River (Oregon Department of Environmental Quality, 1995), and to a lesser extent the North Umpqua and Clackamas River Basins (Anderson and Carpenter, 1998; K.D., Carpenter, unpub. data, 2000). Aside from not meeting water-quality standards, large fluctuations in $\mathrm{DO}$ and $\mathrm{pH}$ indicate possible ecological shifts away from the natural production and food webs of streams to systems that are disturbed. Such streams may become dominated by nuisance species and may not provide adequate food and habitat resources to support native species.

This study would involve at least one summertime longitudinal survey of nutrient concentrations, along with measurements of the minimums and maximums of dissolved-oxygen concentrations and $\mathrm{pH}$, and samplings of periphytic-algal biomass and speciation. Algal species data can be a useful tool in assessing water quality because they integrate long-term conditions that sometimes are not evident at the time of sampling (Lowe and Pan, 1996). The study would also make use of monitoring data from the Ambient Monitoring Program location at Lower Bridge to assess variability of nutrient concentrations over time, and would utilize data from any continuous monitors in the reach, as described elsewhere in this plan, to evaluate the timing and extent of $\mathrm{pH}$ and dissolved oxygen cycling. The findings would be used to determine the severity of $\mathrm{pH}$ and algal problems in the river, the presence of point- or nonpoint- nutrient sources, and the possible effects from different land- or water-management practices, as well as to provide data to support development of TMDLs for the river. Similar studies could also be useful for other reaches experiencing problems with $\mathrm{pH}$, dissolved oxygen, and (or) algae.

Urban and riparian development-There is evidence that the Bend reach of the Deschutes River receives nonpoint urban runoff that is leading to deterioration of water quality. OWQI results for the upper Deschutes River at Mirror Pond in Bend indicate generally good water quality, but that eutrophication in the pond is evidenced by elevated $\mathrm{pH}$, phosphorus concentrations, and biochemical oxygen demand during summer (Oregon Department of Environmental Quality, 1999d). With Deschutes County being one of the fastest growing counties in the State, considerable future urban development is anticipated in Bend, Redmond, Terrebone, La Pine, and elsewhere in the basin. Additionally, nearly all of the private lands in the riparian corridor along the upper Deschutes River, constituting roughly one-third of the land within the Wild and Scenic River and Scenic State Waterways, is subject to development (U.S. Forest Service, 1996b), and additional development is expected along the Little Deschutes River in the La Pine area and elsewhere. Recreational sites are located throughout the public lands along these corridors. Much of the existing public and private development uses septic systems for waste disposal, which can be an important source of 
nutrients to nearby streams, a potential problem that is of concern to resource management agencies in the basin (USDA Forest Service, 1996b; Deschutes County Development Department, 2000; Oregon Department of Environmental Quality, 2000b). Thus, though much of the management of the region's water resources is focussed on reservoirs, irrigation withdrawals, and public lands management, eutrophication from nonpoint sources generated by population growth or agriculture is also a noteworthy future threat to water quality. It is not known, however, what the relative effect is of development compared with the more thoroughly explored effects of reservoir operations and irrigation withdrawals.

Several types of studies could be done to assess the importance of urban runoff and other development to eutrophication in the study area. These could involve collection of nutrient samples above, within, and below urban areas such as Bend and examination of benthic communities (both algae and macroinvertebrates) as indicators of water-quality conditions in those locations. Additionally, naturally occurring stable isotopes of nitrogen or oxygen can be used as tracers of nutrient sources in a river, and caffeine can be analyzed in water to trace human sources of nonpoint pollutants (Seiler and others, 1999). A small reconnaissance study near Bend and (or) La Pine could provide additional direction for future investigations, management, and monitoring in the basin.

\section{Action 37: Reconstruct historical water} quality in reservoirs-Often it is desirable to gauge the effects of land uses on water quality by estimating water-quality conditions prior to the influence of settlers. If "hindcasting" water-quality conditions can be done successfully, reference conditions may be established that can help managers decide on appropriate goals for restoration or that can provide additional longterm data to identify trends. Typically this kind of reconstruction is problematic because of the lack of long-term records, but in lakes and reservoirs the record of water-quality change is often stored in bottom sediments as geochemical data and as the non-reactive, silicon based remains of diatom algae. Diatom species often have specific water-quality tolerances or optimum conditions, which have been characterized and catalogued, so it is possible in many lakes to infer past water-quality conditions on the basis of the species of diatoms found in different layers of sediments in combination with age-dating methods. This technique, often referred to as "paleolimnology," is coming into increasing usage (Stager and others, 1997; Dixit and others, 1999) as a cost effective method of determining the influence of past land uses, including forest clearing, lake manipulations, urbanization, and agriculture, on water quality in lakes and reservoirs.

A paleolimnological study could be undertaken in water bodies such as Crescent Lake or Davis Lake to infer historical conditions and trends, and to extend the trajectory of changes into predictions about current trends. Crane Prairie and Wickiup Reservoirs might be less amenable to this type of study because they are shallow lakes that were historically wetlands and have had more recent construction of dams, so the sedimentation dynamics and amount of organic material might preclude collection of adequate samples. Nonetheless shallow lakes have been successfully studied using sediment diatom records (Sushil Dixit, Queens University, Canada, written commun., 2000). These aspects would bear further consideration during scoping for such a project. To the extent that deterioration of water quality in the reservoirs is reflected as deterioration of water quality in downstream reaches, this type of study would help managers decide on the priority of responses to different water-quality problems in the basin, and could help define historical water quality in rivers prior to flow manipulations from reservoirs.

\subsection{Dissolved Oxygen and $\mathrm{pH}$}

As with nutrients, dissolved oxygen (DO) and $\mathrm{pH}$ data can be used as indicators of the trophic status of streams and lakes. Where diel cycles of DO and $\mathrm{pH}$ are exaggerated, or State standards are not met, it is likely that algal growth and metabolism exceeds that which would have occurred in the absence of effects from humans. Biochemical oxygen demand, from heterotrophic (bacterial) consumption of organic pollutants, can 
also contribute to lowered DO levels. Inclusion of the middle Deschutes River and the Little Deschutes River on the 303(d) list for DO or $\mathrm{pH}$ problems suggests that eutrophication of those and possibly other water bodies is a process that merits watching.

Fortunately, DO and $\mathrm{pH}$ are basic constituents in programs such as the ODEQ Ambient Monitoring Program, and the ODEQ data have been successfully used to provide indications of the status of DO and $\mathrm{pH}$ in the basin. However, data collection in the Ambient Monitoring Program is not timed to capture the extremes of diel $\mathrm{DO}$ and $\mathrm{pH}$ cycling. As for other constituents in this plan, suggested monitoring for $\mathrm{DO}$ and $\mathrm{pH}$ is largely aimed at increasing the availability, efficiency, and utility of collected data; additional suggestions are made for special studies to evaluate the role of management practices on DO and $\mathrm{pH}$. Although temperature monitoring was outlined previously (section 3.3), temperature is included below simply because it is usually measured in conjunction with $\mathrm{DO}$ and $\mathrm{pH}$. No additional temperature monitoring is proposed beyond the suggestions listed in section 3.3.

\subsubsection{Monitoring Objectives and Associated Actions}

\subsubsection{Status, Trends, and Compliance Monitoring}

\section{Objective: Determine the spatial} (longitudinal) variability, diel and seasonal variability, and long-term trends of $\mathrm{DO}$ and $\mathrm{pH}$ in the middle and upper Deschutes River Basin, and

\section{Objective: Determine if $\mathrm{DO}$ and $\mathrm{pH}$ meet State standards, including TMDL loads, by:}

Action 38: Compiling a data base of existing data and evaluating QA/QC data to determine if enough QA data are being properly collected and if data are comparable between sites and agencies;
Action 39: Analyzing existing data to establish baseline conditions and look for changes over time;

Action 40: Establishing continuous monitors, including temperature, $\mathrm{DO}, \mathrm{pH}$, specific conductance, and turbidity, at selected ODEQ ambient monitoring locations; and

Action 41: Using data from continuous monitors to account for diel variations when grab sampling for temperature, $\mathrm{DO}$ and $\mathrm{pH}$. Where reaches are included on the 303(d) list for high $\mathrm{pH}$, do grab samples in the late afternoon to test for peak $\mathrm{pH}$. If reaches are included on the 303(d) list for low DO, do grab samples in the early morning to test for low DO concentrations.

\subsection{Rationale and Explanation}

Actions 38 and 39: Compile existing data, evaluate QA/QC, and analyze data-The first two suggested monitoring actions are essentially identical to the initial actions suggested for temperature and nutrients. As with those constituents, existing data from different organizations would be gathered (fig. 6) and evaluated for its quality and utility for analysis. Analysis would include evaluation of historical conditions, establishment of current baselines, development of conceptual understanding of DO and $\mathrm{pH}$ conditions in the basin that can be used to refine the monitoring network, and where possible, statistically based optimization of the monitoring network.

\section{Action 40: Establish continuous} monitors-There is considerable temporal variability in stream $\mathrm{DO}$ and $\mathrm{pH}$ as well as temperature because of seasonal changes in climate as well as biologically mediated processes. These patterns reduce the value of individual grab samples, especially those taken during midday when conditions do not reflect the extremes possible at a given location. The State standards are written to include an accounting for these diel patterns, including measurements such as a 7-day minimum where data are from a diel 
(morning and evening) monitoring program (Oregon Department of Environmental Quality, 1999c).

Monitors that $\log \mathrm{DO}, \mathrm{pH}$, and temperature on an hourly basis provide data to more fully evaluate the status, trends, and compliance of these constituents with standards, and the processes controlling water quality in streams. Status and compliance are easily determined by querying the resulting databases for the statistics of interestfor instance, maximums, minimums and daily averages - and comparing them with reference concentrations or standards. The status and trends of $\mathrm{DO}$ and $\mathrm{pH}$ can be further evaluated by determining the magnitude of daily fluctuation; the period of lowest (or highest) values during the year; comparisons of daily variability during key seasonal periods from year to year; trends in averages, maximums, or minimums from year to year; and other metrics. Biological and physical processes, including the factors controlling DO and $\mathrm{pH}$ in a stream, also can be investigated by exploring relations of $\mathrm{DO}$ and $\mathrm{pH}$ patterns with such physical factors as temperature, streamflow, and weather; providing a record of unexpected spikes or drops that could be caused by upstream disturbances or sources; or by calculating stream primary production (Odum, 1956; Marzolf and others, 1994, 1998). Continuous data would also be useful for calibration of water-quality models, perhaps in conjunction with TMDL development. It stands to reason to combine recording monitors for $\mathrm{pH}$ and $\mathrm{DO}$ with other recording monitors suggested previously for temperature and turbidity (Actions 14 and 22), which can easily be done with currently available multiparameter recording instruments.

Proper operation of recording monitors for $\mathrm{DO}, \mathrm{pH}$, and other parameters can require a substantial commitment of resources (time and personnel), because most monitors generally need maintenance on a 2- to 4-week basis during the summer, as well as systems for quality assuring, adjusting, and storing recorded data. For instance, ODEQ protocols require daily site visits, and rigorous calibration procedures for DO using Winkler titrations, and USGS protocols require calibrations on a minimum biweekly basis. This commitment could be lessened by deploying recording monitors during select periods of the year, such as the spring and summer, when problems with $\mathrm{DO}$ and $\mathrm{pH}$ are typically the most pronounced.Reaches where such monitors would provide the greatest benefit are those that are known or suspected to have problems with $\mathrm{DO}$ and $\mathrm{pH}$, or are undergoing progressive eutrophication. This includes all of the major reaches of the Deschutes River itself from Wickiup Reservoir to Lake Billy Chinook, and the Little Deschutes River, with the reaches upstream of Bend being the most important. It would be ideal to locate monitors at some or all of the five ODEQ Ambient Monitoring stations in the basin so that these parameters can be used in conjunction with other water-quality data; however these stations do not include housing for equipment such as recorders, so vandalism and theft are potential problems. If Action 10 is enacted, the collocated ODEQ/OWRD locations would the logical places for these monitors; otherwise the OWRD stream-gaging locations could be used to house recording monitors.

\subsubsection{Evaluation Monitoring}

The inclusion of several reaches of the upper Deschutes River on the State's 303(d) list for problems with $\mathrm{DO}$ and $\mathrm{pH}$ implies that TMDLs will be required in coming years to control nutrient transport and eutrophication. This process will likely spark a need to define not just where and when water-quality standards are not being met, but also to refine the understanding of processes controlling eutrophication and better define the timing of nonattainment of waterquality standards. Such an understanding of processes will also necessitate an understanding of the effects that different management practices are having on eutrophication in the basin. This is the basis for the special study suggested below.

\section{Objective: Determine the effects that current management activities are having on $\mathrm{DO}$ and $\mathrm{pH}$, by:}

Action 42: Conducting special studies to evaluate effects of streamflow and nutrient inputs on algal or macrophyte growth, and their effects on $\mathrm{DO}$ and $\mathrm{pH}$, particularly in reaches included on the 303(d) list for $\mathrm{DO}$ and $\mathrm{pH}$, and including 
the effects of reservoirs on downstream reaches.

\subsection{Rationale and Explanation}

Action 42: Evaluate effects of streamflow and nutrient inputs-The proposed study is very similar to Action 36 , and could be accomplished along with the study proposed in that Action. A relatively simple assessment of DO and $\mathrm{pH}$ conditions and nutrient concentrations would provide important insights into the extent of problems with those constituents and their likely causes. The study would focus primarily on reaches included on the 303(d) list for DO, $\mathrm{pH}$, and nutrients (table 2), but also would include other streams for reference purposes. Such a study would include evaluation of diel cycles in $\mathrm{DO}, \mathrm{pH}$, and temperature, as well as characterization of potential nutrient sources such as water released from reservoirs, tributary and ground-water inputs, and urban runoff. It would also include at least a qualitative description of the extent of algal and (or) macrophyte coverage near the study locations. Sampling would be done with a downstream longitudinal approach, beginning at locations immediately downstream from reservoirs, and including the ODEQ ambient monitoring locations as well as selected tributaries (for instance Fall and Spring Rivers, Crescent Creek, Tumalo Creek, Squaw Creek) and other important Deschutes River locations (such as below North Unit Canal and upstream from Lake Billy Chinook). This approach would provide a snapshot of conditions along the length of the Deschutes River and would help refine the understanding of which reaches are most affected by nutrient inputs and $\mathrm{DO}$ and $\mathrm{pH}$ problems, which are less affected, and where some of the possible sources could be. It would also provide data to support the development of TMDLs.

\subsection{Esherichia coli Bacteria}

Contamination of water in the middle and upper Deschutes River Basin with bacteria has not been perceived to be a large problem. Currently, only one reach in the basin (the Little Deschutes River) has been identified on the 303(d) list as possibly having problems with bacterial contamination, but more data are needed to verify the extent of the problem, if one exists. With one exception, all municipal and domestic sewage in the basin is either treated by wetland application, ground-water injection, application to land as irrigation water with essentially no return flows, or in septic systems. Sewage is discharged directly to water (Indian Ford Creek) only from a one guest ranch near Sisters, according to ODEQ's online permit records (Oregon Department of Environmental Quality, 1999b). This lack of direct waste discharges, together with sparse rainfall, most likely contributes greatly to the lack of historical bacterial problems in the river. Nonetheless the occasional deaths elsewhere of swimmers from Esherichia coli (E. coli) contamination contracted at recreational lakes is reason enough to keep bacterial monitoring as part of any long-term monitoring program. In the Deschutes River Basin, there are potential sources of pathogenic bacteria which are worth consideration for future monitoring. These sources include increased development in riparian and floodplain areas, increased recreation in the river and in riparian areas, livestock grazing, and urbanization. Additionally, there has been very little bacterial data collected except by the ODEQ Ambient Monitoring Program and one site that the City of Bend monitors on upper Tumalo Creek near the municipal drinking-water intake, so it is possible that there are additional problem areas that have not yet been investigated. Suggested long-term monitoring for bacteria in this plan is targeted towards maintenance of the current monitoring regime, with minor additions to include data analysis and interpretation of existing data, inclusion of a few strategic locations that have not been sampled in the past, and some reconnaissance sampling to verify that bacterial contamination remains a relatively minor problem in the basin.

\subsubsection{Monitoring Objectives and Associated Actions}

\subsubsection{Status, Trends, and Compliance Monitoring}

\author{
Objective: Determine the spatial \\ (longitudinal) and seasonal \\ variability, and long-term trends \\ of $E$. coli bacteria in the middle
}


and upper Deschutes River

Basin, and

\section{Objective: Determine if E. coli exceeds}

State standards in the middle

and upper Deschutes River

Basin, by:

Action 43: Compiling data base of existing data and evaluating QA/QC data to determine if enough QA data are being properly collected and if data are comparable between sites and agencies;

Action 44: Analyzing existing data to establish baseline conditions, look for changes over time, and determine adherence to State standards; and

Action 45: Maintaining current ODEQ monitoring program, with modifications to include stations on Squaw Creek, Tumalo Creek, or other locations as indicated by analysis of existing data, data gaps, or special studies.

\subsection{Rationale and Explanation}

Action 43: Compile existing data and evaluate QA/QC data-As for other monitoring constituents, an understanding of the status of bacterial contamination in the basin could benefit from a comprehensive analysis of existing data. The first step in this analysis would be to ensure the quality and comparability of those data. For example, in 1996 the State standard for bacterial contamination changed from one based on fecal streptococci to one based on E. coli bacteria, so it would be useful to verify that those sampling for bacteria in the basin are sampling for the same strains of bacteria and using comparable methods. Bacterial samples are also particularly susceptible to contamination or mishandling that can bias the results, so it will be important to examine available datasets for blank sample results.

Action 44: Analyze existing data-Once the quality of available bacteria data has been determined, the data themselves can be analyzed. Although ODEQ data from the ambient monitoring program are published online (Oregon Department of Environmental Quality, 1999d), data specifically on bacteria are not presented. Issues that would be useful to address include whether any trends in bacteria alone are evident; if there are particular times of the year that bacterial problems are more severe than others; if there are popular swimming locations, including lakes, that are notably unrepresented in historical data collection and that merit addition to the monitoring network; if urban runoff is increasing bacterial contamination in places such as Mirror Pond in Bend; if agricultural activities are contributing significant bacterial contamination to the river system; and if there are other factors such as streamflow, nutrients, or TSS that can be related to bacterial counts at some sampling locations.

Action 45: Maintain current monitoring network-The ODEQ Ambient Monitoring network in the study area, with additional monitoring on upper Tumalo Creek by the City of Bend, provides relatively good coverage of the major reaches considered in this plan. The most significant data gaps are the tributaries to the middle Deschutes River that are also considered herein-Tumalo Creek near the mouth and Squaw Creek. With the exception of the Bureau of Reclamation's samplings at its Deschutes River Basin sites, lakes are not regularly sampled in the basin either. These could be monitored at the same general frequency as the ODEQ Ambient Monitoring sites, although a shifting of the bacterial monitoring schedule to be weighted during summer, low-flow months when recreation is the most prevalent is suggested.

\subsubsection{Evaluation Monitoring}

Objective: Determine the risks to human health from exposure to pathogenic bacteria at popular recreation areas in the middle and upper Deschutes River Basin, by:

Action 46: Conducting special studies of popular recreation areas to determine bacterial counts or incidents of illness due to bacterial exposure. 


\subsection{Rationale and Explanation}

Action 46: Evaluate recreational areasThe intent of this special study is to determine if there is a need for additional investigation into bacterial contamination. This study could be accomplished either by sampling for pathogenic bacteria at commonly used recreation sites or by conducting surveys at recreation sites to investigate any problems with rashes or other sicknesses that could be related to bacterial contamination. Because the river typically has steady velocities, with few stagnant or nonflowing areas, and there are no known sewage inputs to the river, it is unlikely that bacterial contamination in the upper Deschutes River or its major tributaries is a problem. However, with septic systems being prevalent in some areas, or in any areas that have low velocities and high amounts of recreation or animal-waste inputs (such as Mirror Pond in Bend, the Little Deschutes River along Burgess Road, the Deschutes River at Harper's Bridge, and the La Pine State Recreational area, or some locations where people swim in irrigation canals), there may be cause for localized concern. Additionally, Haystack Reservoir, though technically outside of the study area for this monitoring plan, receives most of its water directly from the upper Deschutes River irrigation system and could be a location of bacterial contamination in swimming areas. Followup investigations could be done if any areas are indicated to have especially high risks of bacterial contamination.

\subsection{Additional monitoring}

Several potentially important water-quality topics are not included above, either because they are not typically handled in a classical "monitoring" sense, with scheduled, repeated sampling over a long term, or because there is little information to suggest that they represent significant issues in the study area. Nonetheless, these topics may warrant consideration for inclusion into various parts of this monitoring plan or for reconnaissance studies, in order to ensure that they do not become significant problems without warning. These topics include monitoring for nonindigenous (introduced) species, aquatic macroinvertebrates, and potentially-toxic constituents such as trace elements or synthetic organic compounds. For each of these, potential monitoring objectives are given below along with several suggested, preliminary monitoring actions, in order to serve as a basis for future consideration; however discussion is limited to a brief introduction. If the importance of one of these topics is elevated in the future such that it warrants being incorporated more formally into a regional monitoring network, designing a monitoring approach for it will most likely require an assessment and scoping exercise at least similar to those above, if not more intensive. It would thus be premature to propose in-depth monitoring programs for these items in the absence of additional information.

\subsubsection{Nonindigenous species}

Nonindigenous, or introduced, species can have devastating effects on aquatic ecosystems by disrupting food chains, competing for food and habitat resources, and preying excessively on native species. As a result of the 1990 Aquatic Nuisance Prevention and Control Act and 1996 National Invasive Species Act, Congress established an Aquatic Nuisance Species Task Force, which has a Western Regional Panel (http:// www.wrp-ans.org/index.htm). Information on aquatic nonindigenous species can also be obtained for the State of Oregon through Dr. Mark Sytsma at Portland State University. In the middle and upper Deschutes River Basin there are known concerns with the threespine stickleback

(Gasterosteus aculeatus), which is spreading throughout the basin and can disrupt production of trout, and which is already included in fish species monitoring by the ODFW (table 4). Other fish are also causing localized management problems. East Lake, Paulina Lake, Big Lava and Little Lava Lakes, Davis Lake, and Crane Prairie and Wickiup Reservoirs are all experiencing problems with Tui chub (Gila bicolor). Crane Prairie Reservoir is also having problems with largemouth bass (Micropterus salmoides), brown bullhead (Ictalurus nebulosus), and potentially crappie (Pomoxis sp.) and bluegill (Lepomis macrochirus). Largemouth bass are also found in Davis Lake, and problems with some of these fish also exist in the Ochoco and Prineville reservoirs (Steve Marx, Oregon Department of Fish and Wildlife, written 
commun., October 1999). Some invasive species such as rainbow trout, kokanee salmon, and bass are popular gamefish and they are often managed to maintain their populations. Invasive aquatic plants such as hydrilla can dramatically alter habitat for fish and other biota. In many cases preventing the spread of invasive species can be dependent on education and the input from the public, and several of the suggested actions below are intended to make use of this fact by making the public an integral part of the monitoring process.

\subsubsection{Monitoring Objectives and Associated Actions}

\section{Objective: Keep track of the extent and distribution of nonindigenous species in the upper Deschutes River and major tributaries,}

Objective: Determine changes over time in nonindigenous species populations, and

Objective: Provide an early warning system for the invasion of new nonindigenous species, by:

Action 47: Working with the Western Regional Panel of the Aquatic Nuisance Species Task Force to maintain a list of invasive species of concern in the middle and upper Deschutes River Basin, and participating in the development of a statewide plan for control and prevention of invasive species introductions;

Action 48: Establishing a person or position in the basin for resource professionals and members of the public to contact with questions about invasive species or to report sightings;

Action 49: Working to educate the public on issues associated with invasive species through school curriculums, interpretive signs at recreational areas and river access points, fliers accompanying fishing licenses, and other mechanisms; and
Action 50: Conducting periodic surveys in areas of high risk and sensitivity, or known invasion of nonindigenous species, to estimate coverage or populations.

\subsubsection{Invertebrates}

Aquatic macroinvertebrates can be a useful tool for evaluating water-quality and streamecosystem integrity because many species have well defined tolerances. These species are, therefore, indicative of the types of water-quality and habitat conditions a stream experiences, integrated over the duration of the invertebrate community's existence at a location. For this reason, in addition to the general importance of macroinvertebrates as food resources for fish, macroinvertebrate monitoring has been used increasingly in recent years as a supplement to water-quality monitoring. As with habitat and geomorphology monitoring, there have apparently been numerous past individual studies of macroinvertebrates in streams, done for many individual reasons and with differing objectives and methods, by varying organizations. One of the more comprehensive recent studies was done by the ODEQ as part of R-EMAP in 1997-98. Waterchemistry data from that study have been reported (Oregon Department of Environmental Quality, 1999e), but macroinvertebrate and habitat data have not.

\subsubsection{Monitoring Objectives and Associated Actions}

Objective: Use macroinvertebrate community data to augment evaluation of water-quality and habitat conditions, and to evaluate adequacy of food resources for fish in the middle and upper Deschutes River Basin and major tributaries, by:

Action 51: Compiling existing macroinvertebrate community and data for the basin, including information on objectives, date of study, study area and locations, field and laboratory protocols used, level of taxonomic identification 
used, quality-assurance data available, and data storage format;

Action 52: Using existing macroinvertebrate data, if possible, to assess current conditions and changes over time in macroinvertebrate assemblages and indicated water and habitat quality; and

\section{Action 53: Using information from} macroinvertebrate analysis to refine monitoring for macroinvertebrates, habitat, and water quality if warranted.

\subsubsection{Toxics}

Two water samples from Wickiup Reservoir collected by the Bureau of Reclamation (Larry Zakrajsek, Bureau of Reclamation, written commun., December 1999) indicated that mercury was detected, at levels close to the analytical detection limit used, during 1984 and 1991. However, mercury is known to be difficult to sample accurately without special, clean techniques (Krabbenhoft and Rickert, 1995), and it is likely that these detected concentration were incidences of sample contamination. Followup sampling for mercury in fish tissues from Wickiup Reservoir revealed tissue concentrations that are similar to those in other lakes with no known mercury problems, and were well below USEPA health advisory levels (Doug Drake, Oregon Department of Environmental Quality, written commun., 2000). Because of historical problems with sample contamination, most current mercury sampling is done using fish tissue or bed sediment rather than water. Although other lakes in the Cascades, including the nearby East Lake in Newberry Crater, are known to have mercury problems originating from a variety of sources (Oregon Department of Environmental Quality, 1996), there are no known mercury deposits near Wickiup Reservoir or other upper Deschutes River Basin impoundments (Ronald Geitgy, Department of Geology and Mineral Industries, oral commun., 2000).

Currently, there is no evidence to indicate that toxic constituents in the waters of the middle and upper Deschutes River Basin are negatively effecting fish or other aquatic biota. Aside from mercury samples taken in water from East Lake (Morgan and others, 1997) and by the Bureau of Reclamation in their impoundments, no other investigations of toxic constituents are known to have been done in the basin. There are, however, several possible sources of different classes of toxic compounds to the streams, including urban runoff of metals, greases, solvents, and pesticides from Bend, Redmond, and other municipalities; vector control; and pesticide applications near homes, along rights-of-ways, golf courses, in irrigation canals, and to agricultural lands. There is only a small number of industrial permits for discharges to streams in the basin, including a wood products manufacturer near La Pine on the Little Deschutes River. Suggested monitoring actions in this section are principally reconnaissance in nature; additional monitoring beyond a reconnaissance survey would require consideration of the results of that survey before a reasonable scope of study could be decided on.

\subsubsection{Monitoring Objectives and Associated Actions}

Objective: Determine if toxic constituents are present in the water, bed sediment, or biota of the middle and upper Deschutes River Basin at concentrations that could potentially affect the health of aquatic biota or humans, or that warrant additional investigation, by:

Action 54: Assembling information on all permitted point-source discharges to rivers in the basin, including constituents discharged, estimated load, and location of discharge, and information on pesticides used historically and currently in the basin, and including irrigation canals;

Action 55: Assembling information on any previous investigations of toxic constituents done in the basin; 
Action 56: Using the information collected above, and knowledge of basin hydrology, to conduct reconnaissance samplings for trace elements in water and in sediments, dissolved pesticides in water, dissolved pharmaceuticals in water, and (or) polycyclic aromatic hydrocarbons (PAHs) in water and sediments, using the lowest practicable analytical detection limits;

Action 57: Changing the protocols used for sampling mercury in water bodies, including reservoirs, to the use of fish tissues and sediment, rather than water, as sampling media;

Action 58: Communicating the results of the above reconnaissance sampling to those charged with coordination of the regional long-term monitoring plan, the public, and other agencies in the basin; and

Action 59: Deciding on the need for additional monitoring or studies of toxic constituents on the basis of reconnaissance study results.

\subsection{Implementation}

Objectives and actions for coordinated, regional monitoring from the previous section are summarized by topic in table 6. Implementation of the monitoring plan and allocation of the monitoring actions among organizations will be a major task for the Upper Deschutes Water Quality Monitoring Committee and its members. Possible steps to implementation include the determination of logical responsibilities based on agency missions and expertise, and organization of the actions into phases that can be implemented sequentially. These steps are elaborated below.

\subsection{Summary of Proposed M onitoring Actions by Organization}

For the most part, monitoring actions were presented in this report without regard to responsibilities of individual organizations, and decisions on responsibilities will best be made by those coordinating the monitoring. There are some suggested monitoring actions, however, that could logically be done by specific organizations with jurisdiction over particular geographical areas or authority over particular water uses. A brief summary is given here to indicate the actions that might be allocated to each organization as a logical part of this monitoring program. It is emphasized that this in no way represents decisions on organizational responsibilities, but rather provides an alternative way to organize some of the suggested monitoring actions, so that involved organizations can anticipate the ways in which they can contribute to coordinated, regional monitoring. Many other suggested monitoring actions, including evaluation monitoring or special studies, would possibly be let out by contract, administered through agreements among agencies, or performed in cooperative arrangements among multiple organizations.

All involved organizations-Several generalized actions apply to most if not all of the organizations involved in monitoring. Most importantly, the organizations can work together to develop a process for coordinating and managing monitoring at a regional scale. These include primarily Actions 1-7. Additional actions having to do with assembly of existing data could be requested of most of the agencies in the basin for assembling their own data, although analysis of these datasets might be put out for contracts. Most of the organizations involved or potentially affected by this plan also have additional data activities they are involved in. Their awareness of this plan's elements, and any efforts they can make to help those activities work in conjunction with the plan, will help broaden the relevance of those activities and of this plan.

Oregon Water Resources Department-As the principal agency monitoring streamflow in the study area, most of the monitoring actions related to streamflow are likely to be the domain of OWRD. These include Actions 8-10. In addition, it is suggested that OWRD and ODEQ jointly consider ways to collocate the stream-gaging and ambient monitoring stations in order to make the 
Table 6. Summary of objectives and suggested monitoring actions for coordinated, regional water-quality monitoring in the upper Deschutes River Basin

[Suggested monitoring actions are described in more complete detail in section 3.0. Suggested phases refer to the general sequence in which actions would be initiated and are explained in table 1. OWRD, Oregon Water Resources Department; EPA, U.S. Environmental Protection Agency; ODEQ, Oregon Department of Environmental Quality; QA/QC, Quality Assurance/Quality Control; TMDL, Total Maximum Daily Loads; TSS, Total Suspended Solids]

\begin{tabular}{|c|c|c|c|c|}
\hline \multirow{2}{*}{ Monitoring type } & \multirow{2}{*}{ Objective } & \multicolumn{2}{|r|}{ Related monitoring actions } & \multirow{2}{*}{ 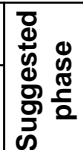 } \\
\hline & & Number & Suggested action (short description) & \\
\hline
\end{tabular}

\section{Overall Monitoring Program Management}

\begin{tabular}{|c|c|c|c|}
\hline $\begin{array}{l}\text { Integration, } \\
\text { Coordination, } \\
\text { \& Efficiency }\end{array}$ & $\begin{array}{l}\text { Integrate existing monitoring efforts among } \\
\text { participating organizations to increase efficiency, } \\
\text { minimize redundancy, and improve data quality } \\
\text { and comparability }\end{array}$ & $\begin{array}{l}\text { 1. Establish a mechanism for coordination and support of regional monitoring } \\
\text { program } \\
\text { 2. Conduct periodic reviews of monitoring program ( } 1 \text { and } 5 \text { year intervals) } \\
\text { 3. Establish common protocols to enable data comparison } \\
\text { 4. Develop Quality Assurance Plans for data collection elements } \\
\text { 5. Create a data management strategy to allow data sharing among agencies } \\
\text { 6. Work to increase availability of information, reports, and other products to other } \\
\text { agencies and the public }\end{array}$ & $\begin{array}{l}1 \\
2 \\
1 \\
1 \\
1 \\
1\end{array}$ \\
\hline Data Gaps & $\begin{array}{l}\text { Identify crucial data gaps in existing monitoring } \\
\text { efforts that can be filled with minor } \\
\text { modifications of existing programs } \\
\text { Identify data gaps or other research questions } \\
\text { which limit or prevent success of additional } \\
\text { monitoring efforts }\end{array}$ & $\begin{array}{l}\text { 7. Analyze and communicate data from previously completed studies in the } \\
\text { Deschutes Basin to help formulate baseline(s) and refine issues (see below) }\end{array}$ & $1-2$ \\
\hline \multicolumn{4}{|c|}{ Discharge } \\
\hline $\begin{array}{l}\text { Data Utility \& } \\
\text { Availability }\end{array}$ & $\begin{array}{l}\text { Increase availability of current and historical data } \\
\text { to other agencies and the public }\end{array}$ & $\begin{array}{l}\text { 8. Update streamflow records for all stations and publish data (as paper reports or } \\
\text { electronically) }\end{array}$ & 2 \\
\hline $\begin{array}{l}\text { Status \& } \\
\text { Trends } \\
\text { Monitoring }\end{array}$ & $\begin{array}{l}\text { Provide flow data that can be used in combination } \\
\text { with water-quality data for load calculations, to } \\
\text { support evaluation of sources and transport of } \\
\text { water-quality constituents } \\
\text { Improve predictive capabilities for flow entering } \\
\text { reservoirs and upper Deschutes River in order to } \\
\text { more adequately allocate water resources } \\
\text { downstream }\end{array}$ & $\begin{array}{l}\text { 9. Continue current network to measure flows in all major streams, tributaries, and } \\
\text { irrigation canals } \\
\text { 10. Collocate OWRD stream-gaging locations with ODEQ Ambient Monitoring } \\
\text { Stations in order to better combine streamflow and water-quality data } \\
\begin{array}{l}\text { 11. Develop process-based or statistical hydrologic models to increase predictability of } \\
\text { snowmelt and ground-water systems to reservoirs and to key river reaches }\end{array}\end{array}$ & All \\
\hline
\end{tabular}


Table 6. Summary of objectives and suggested monitoring actions for coordinated, regional water-quality monitoring in the upper Deschutes River Basin-Continued

[Suggested monitoring actions are described in more complete detail in section 3.0. Suggested phases refer to the general sequence in which actions would be initiated and are explained in table 1. OWRD, Oregon Water Resources Department; EPA, U.S. Environmental Protection Agency; ODEQ, Oregon Department of Environmental Quality; QA/QC, Quality Assurance/Quality Control; TMDL, Total Maximum Daily Loads; TSS, Total Suspended Solids]

\begin{tabular}{|c|c|c|c|}
\hline \multirow{2}{*}{ Monitoring type } & \multirow{2}{*}{ Objective } & Related monitoring actions & \multirow{2}{*}{ 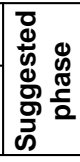 } \\
\hline & & Suggested action (short description) & \\
\hline \multicolumn{4}{|c|}{ Water Temperature } \\
\hline $\begin{array}{c}\text { Data Utility \& } \\
\text { Availability }\end{array}$ & $\begin{array}{l}\text { Increase availability of existing and future } \\
\text { temperature data and analysis }\end{array}$ & $\begin{array}{l}\text { 12. Compile databases of existing data among agencies and evaluate QA/QC data } \\
\text { 13. Analyze existing data }\end{array}$ & $\begin{array}{l}1 \\
2\end{array}$ \\
\hline $\begin{array}{l}\text { Status, Trends, } \\
\text { and } \\
\text { Compliance } \\
\text { Monitoring }\end{array}$ & $\begin{array}{l}\text { Determine the spatial variability, diel and seasonal } \\
\text { variability, and long-term trends, and } \\
\text { Provide data to determine if water temperatures } \\
\text { exceed State standards and to support } \\
\text { development of TMDLs for the basin }\end{array}$ & $\begin{array}{l}\text { 14. Collect data for temperature using continuous monitors rather than by grab } \\
\text { sampling, where possible, to account for diel and seasonal variations } \\
\text { 15. Modify existing temperature network by removing redundant monitors, and } \\
\text { installing new monitors to fill data gaps for support of TMDLs } \\
\text { 16. Develop a temperature model for } 303(\mathrm{~d}) \text { listed reaches to support development of } \\
\text { TMDLs and to determine effects of flow variations from reservoirs, irrigation } \\
\text { withdrawals, and other management actions }\end{array}$ & 2 \\
\hline $\begin{array}{l}\text { Evaluation } \\
\text { Monitoring }\end{array}$ & $\begin{array}{l}\text { Determine the effects that current management } \\
\text { activities are having on water temperature }\end{array}$ & $\begin{array}{l}\text { 17. Consider special studies to evaluate effects on water temperature from surface or } \\
\text { ground water withdrawals, floodplain and riparian development, and restoration } \\
\text { projects on stream temperatures }\end{array}$ & 3 \\
\hline
\end{tabular}

Turbidity / Sediment Transport

\begin{tabular}{|c|c|c|c|}
\hline $\begin{array}{l}\text { Status, Trends, } \\
\text { and } \\
\text { Compliance } \\
\text { Monitoring }\end{array}$ & $\begin{array}{l}\text { Determine spatial (longitudinal) variability, diel } \\
\text { and seasonal variability, and long-term trends in } \\
\text { suspended sediment concentrations } \\
\text { Determine if suspended sediment (TSS/turbidity) } \\
\text { meets State and Federal water-quality criteria } \\
\text { (including TMDL loads) }\end{array}$ & $\begin{array}{l}\text { 18. Use TSS as preferred data-collection protocol, with continuous turbidity } \\
\text { monitoring at selected locations } \\
\text { 19. Compile databases of existing data among agencies and evaluate QA/QC data } \\
\text { 20. Analyze existing data } \\
\text { 21. Establish periodic sampling for TSS at OWRD gaging stations on Deschutes River } \\
\text { below Wickiup Reservoir, and Little Deschutes River at La Pine } \\
\text { 22. Establish continuous turbidity monitoring locations, with priority stations in } \\
\text { reaches downstream of Wickiup Reservoir. }\end{array}$ & $\begin{array}{l}1 \\
2\end{array}$ \\
\hline $\begin{array}{l}\text { Evaluation } \\
\text { Monitoring }\end{array}$ & $\begin{array}{l}\text { Determine effects of variations in streamflow } \\
\text { from reservoir operations and irrigation } \\
\text { withdrawals on downstream sediment } \\
\text { concentrations, including daily and seasonal } \\
\text { effects } \\
\text { Provide data to develop sediment - discharge } \\
\text { rating curves below Wickiup Reservoir }\end{array}$ & $\begin{array}{l}\text { 23. Conduct a pilot study to refine relations between suspended sediment, TSS, and } \\
\text { turbidity in upper Deschutes down to Bend, and including Little Deschutes River } \\
\text { 24. Conduct a special study to evaluate the relationship between bedload transport and } \\
\text { changes in flow, and determine sediment sources below Wickiup Reservoir to Bend }\end{array}$ & 3-4 \\
\hline
\end{tabular}


Table 6. Summary of objectives and suggested monitoring actions for coordinated, regional water-quality monitoring in the upper Deschutes River Basin-Continued

[Suggested monitoring actions are described in more complete detail in section 3.0. Suggested phases refer to the general sequence in which actions would be initiated and are explained in table 1. OWRD Oregon Water Resources Department; EPA, U.S. Environmental Protection Agency; ODEQ, Oregon Department of Environmental Quality; QA/QC, Quality Assurance/Quality Control; TMDL, Total Maximum Daily Loads; TSS, Total Suspended Solids

\begin{tabular}{|c|c|c|c|c|}
\hline \multirow{2}{*}{ Monitoring type } & \multirow{2}{*}{ Objective } & \multicolumn{2}{|r|}{ Related monitoring actions } & \multirow{2}{*}{ 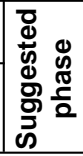 } \\
\hline & & Number & Suggested action (short description) & \\
\hline
\end{tabular}

Physical Channel Morphology/Aquatic Habitat

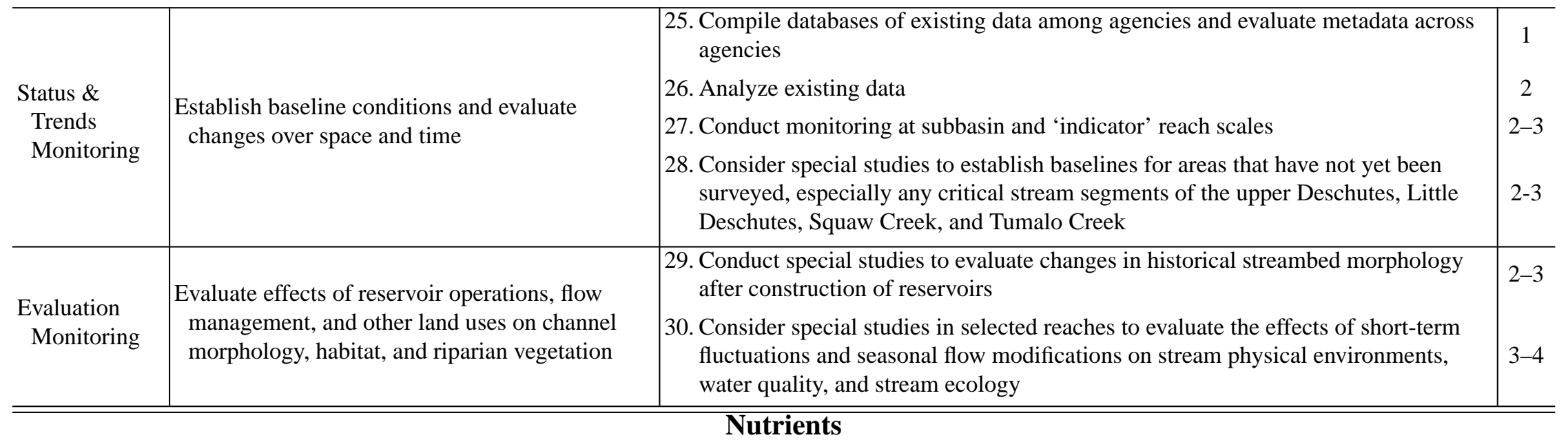

\begin{tabular}{|c|c|c|c|}
\hline $\begin{array}{l}\text { Status, Trends, } \\
\& \\
\text { Compliance } \\
\text { Monitoring }\end{array}$ & $\begin{array}{l}\text { Determine spatial (longitudinal) and seasonal } \\
\text { variability, and long-term trends, in nutrient } \\
\text { concentrations in streams } \\
\text { Determine if nutrient concentrations meet State } \\
\text { and Federal water-quality criteria (including } \\
\text { TMDLs) }\end{array}$ & $\begin{array}{l}\text { 31. Compile databases of existing data among agencies and evaluate QA/QC data } \\
\text { 32. Analyze existing data } \\
\text { 33. Use ODEQ's sample collection, preservation, and analytical protocols as preferred } \\
\text { nutrient protocols for monitoring } \\
\text { 34. Increase frequency of sampling in Wickiup Reservoir and Crescent Lake } \\
\text { 35. Maintain awareness of EPA Region 10's effort to determine regional nutrient } \\
\text { criteria for streams }\end{array}$ & $\begin{array}{l}2 \\
3\end{array}$ \\
\hline $\begin{array}{l}\text { Evaluation } \\
\text { Monitoring }\end{array}$ & $\begin{array}{l}\text { Determine effects of elevated nutrient } \\
\text { concentrations on trophic status in selected } \\
\text { reaches where eutrophication is indicated } \\
\text { Determine effects of selected management } \\
\text { activities on nutrient concentrations in streams }\end{array}$ & $\begin{array}{l}\text { 36. Conduct special studies to evaluate various aspects of nutrients, eutrophication, or } \\
\text { resource management in the study area. } \\
\text { 37. Determine historical changes in reservoir water quality since construction by } \\
\text { examination of algal record in lake sediments }\end{array}$ & $3-4$ \\
\hline
\end{tabular}


Table 6. Summary of objectives and suggested monitoring actions for coordinated, regional water-quality monitoring in the upper Deschutes River Basin-Continued

[Suggested monitoring actions are described in more complete detail in section 3.0. Suggested phases refer to the general sequence in which actions would be initiated and are explained in table 1. OWRD Oregon Water Resources Department; EPA, U.S. Environmental Protection Agency; ODEQ, Oregon Department of Environmental Quality; QA/QC, Quality Assurance/Quality Control; TMDL, Total Maximum Daily Loads; TSS, Total Suspended Solids

\begin{tabular}{|c|c|c|c|c|}
\hline \multirow{2}{*}{ Monitoring type } & \multirow{2}{*}{ Objective } & \multicolumn{2}{|r|}{ Related monitoring actions } & \multirow{2}{*}{ 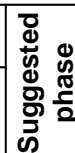 } \\
\hline & & Number & Suggested action (short description) & \\
\hline
\end{tabular}

\section{Dissolved Oxygen and pH}

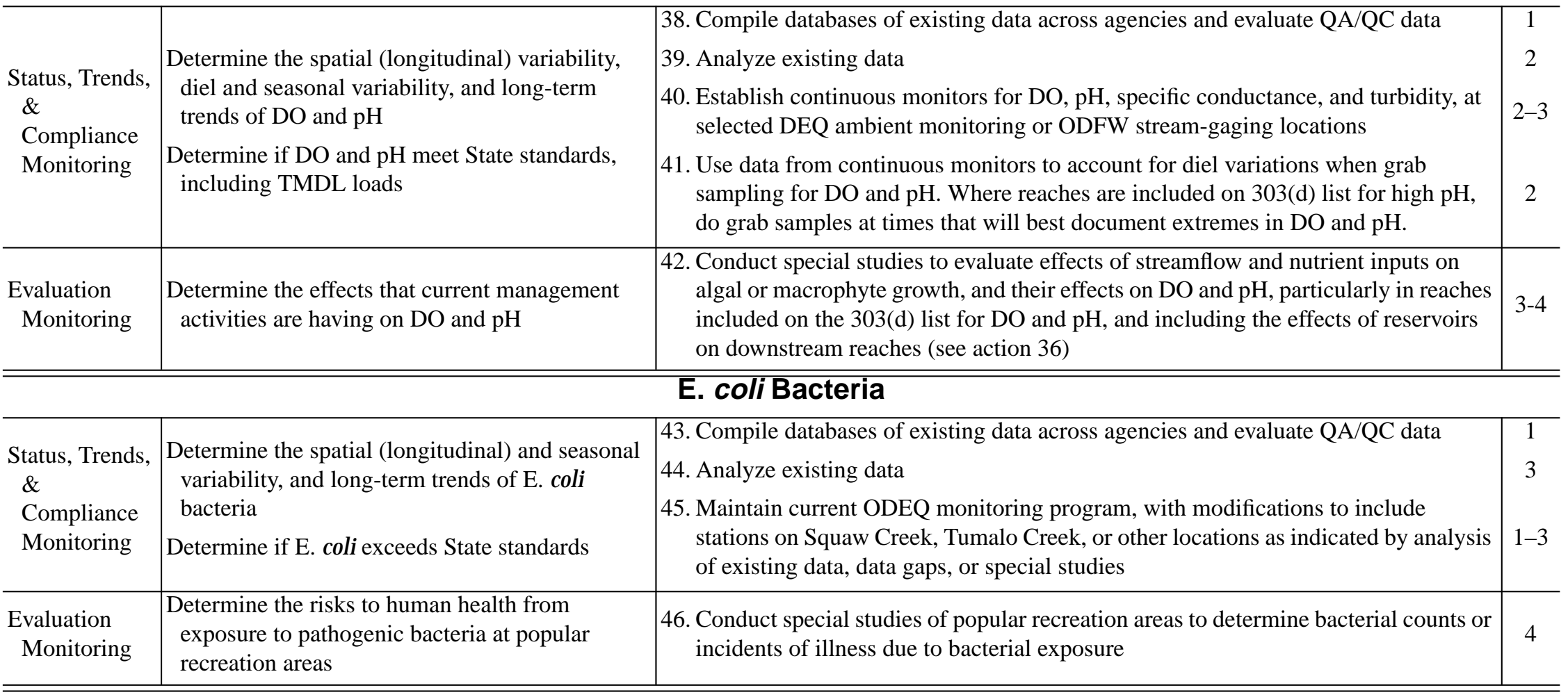


Table 6. Summary of objectives and suggested monitoring actions for coordinated, regional water-quality monitoring in the upper Deschutes River Basin

[Suggested monitoring actions are described in more complete detail in section 3.0. Suggested phases refer to the general sequence in which actions would be initiated and are explained in table 1. OWRD, Oregon Water Resources Department; EPA, U.S. Environmental Protection Agency; ODEQ, Oregon Department of Environmental Quality; QA/QC, Quality Assurance/Quality Control; TMDL, Total Maximum Daily Loads; TSS, Total Suspended Solids]

\begin{tabular}{|c|c|c|c|}
\hline Topic & Objective & Suggested actions (short description) & 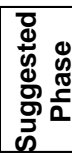 \\
\hline \multicolumn{4}{|c|}{ Additional Monitoring } \\
\hline $\begin{array}{l}\text { Nonindigenous } \\
\text { species }\end{array}$ & $\begin{array}{l}\text { Track the extent and distribution of nonindigenous } \\
\text { species in the upper Deschutes River and major } \\
\text { tributaries } \\
\text { Determine changes over time in nonindigenous } \\
\text { species populations } \\
\text { Provide an early warning system for the invasion } \\
\text { of new nonindigenous species }\end{array}$ & $\begin{array}{l}\text { 47. Work with the Western Regional Panel of the Aquatic Nuisance Species Task Force } \\
\text { to maintain a list of invasive species of concern, and participate in the development } \\
\text { of a statewide plan for control and prevention of invasive species introductions } \\
\text { 48. Establish a person or position in the basin for resource professionals and members } \\
\text { of the public to contact with questions about invasive species or to report sightings } \\
\text { 49. Work to educate the public on issues associated with invasive species } \\
\text { 50. Conduct periodic surveys to estimate coverage or populations }\end{array}$ & $\begin{array}{c}2 \\
3-4 \\
4\end{array}$ \\
\hline Invertebrates & $\begin{array}{l}\text { Use macroinvertebrate community data to } \\
\text { augment evaluation of water-quality and habitat } \\
\text { conditions, and to evaluate adequacy of food } \\
\text { resources for fish }\end{array}$ & $\begin{array}{l}\text { 51. Compile existing macroinvertebrate community data for the basin } \\
\text { 52. Use existing macroinvertebrate data, if possible, to assess current conditions and } \\
\text { changes over time in macroinvertebrate assemblages and indicated water and } \\
\text { habitat quality } \\
\text { 53. Use information from macroinvertebrate analysis to refine monitoring for } \\
\text { macroinvertebrates, habitat, and water quality if warranted }\end{array}$ & 1 \\
\hline Toxics & $\begin{array}{l}\text { Determine if toxic constituents are present in } \\
\text { water, sediments, or biota at concentrations that } \\
\text { could potentially impact the health of aquatic } \\
\text { biota or humans, or that warrant additional } \\
\text { investigation }\end{array}$ & $\begin{array}{l}\text { 54. Assemble information on all permitted point source discharges to rivers and any } \\
\text { existing information on toxics in water, sediment, or biota } \\
\text { 55. Assemble information on any previous investigations of toxic constituents } \\
\text { 56. Use existing information and knowledge of basin hydrology, to conduct } \\
\text { reconnaissance samplings for trace metals in water and in bed sediment, dissolved } \\
\text { pesticides in water, and/or polycyclic aromatic hydrocarbons (PAHs) in water and } \\
\text { sediments } \\
\text { 57. Change the protocols used for sampling mercury in water bodies, including } \\
\text { reservoirs, to the use of fish tissues and sediment, rather than water as sampling } \\
\text { media } \\
\text { 58. Communicate the results of the reconnaissance samplings } \\
\text { 59. Decide on the need for additional monitoring or studies of toxic constituents on the } \\
\text { basis of reconnaissance study results }\end{array}$ & 2 \\
\hline
\end{tabular}


best use of both streamflow and water-quality data (Action 10). If continuous water-quality and (or) turbidity monitors are installed (Actions 22 and 40 ), it would be useful to locate these monitors at OWRD gaging stations (although the monitors need not necessarily be serviced by OWRD personnel) where possible.

\section{Oregon Department of Environmental}

Quality-Most of the routine water-quality data collection in the basin is conducted by ODEQ at its Ambient Monitoring stations, so a variety of suggested actions relating to water-quality sampling could logically be carried out by ODEQ. These include decisions about collocating ambient monitoring stations and stream-gaging stations where possible (Action 10), participating in USEPA efforts to establish regional nutrient criteria (Action 35), and modifying sampling programs to better account for diel cycling of temperatures, dissolved oxygen, and $\mathrm{pH}$ (Action 41). If continuous water-quality and (or) turbidity monitors are installed anywhere, such as at ODEQ ambient monitoring locations or OWRD gaging stations, ODEQ might be well positioned to operate those monitors. At the least, they would be appropriate to provide training and to oversee the installation and operation of the monitors.

\section{Oregon Department of Fish and}

Wildlife-The parts of this monitoring plan that overlap with ODFW missions include collecting aquatic habitat data (Actions 27-29), particularly on State lands, and several aspects involving endangered or nonindigenous species (Actions 4750). Habitat and geomorphology monitoring might also be performed by the Forest Service or the BLM, especially in lands that are under Federal jurisdiction, so it is likely that agreements among these agencies would be employed to provide coordinated monitoring of habitat.

\section{U.S. Forest Service and Bureau of Land} Management-The Forest Service and the BLM collect data on temperature, turbidity and sediment, and stream habitat /channel geometry at a variety of locations within the study area. As indicated above, habitat and channel geometry monitoring under this plan, including creating an inventory and database of existing information, would likely be conducted jointly between ODFW, the Forest Service, and the BLM (Actions 25-28). Because the reaches immediately downstream of
Wickiup Reservoir are predominantly managed by the Forest Service, that agency might also administer special studies to evaluate the effects of reservoir management on turbidity (Actions 23 and 24), channel morphology and sedimentation (Actions 29 and 30), nutrients (Action 36), and DO and $\mathrm{pH}$ (Action 42). There are some temperature monitoring stations maintained by the Forest Service and BLM that are redundant with those of other organizations, and which could provide more information if they were moved to different locations to help fill data gaps (Action 15).

Bureau of Reclamation-The major impoundments of the upper Deschutes River Basin, Wickiup and Crane Prairie Reservoirs and Crescent Lake, are managed by the BOR, and any in-reservoir monitoring actions suggested in this plan would likely be administered by the BOR. Although most of the focus of this plan is on the reaches downstream of the reservoirs, information on reservoir water quality is important because of their large influence on streamflow, water quality, and transport processes in the upper Deschutes River. More frequent reservoir monitoring (Action 34) would most likely be undertaken by or in cooperation with the BOR, as would a possible study using sediment diatom records to reconstruct the water-quality history of the reservoirs (Action 37). The BOR could also be an important partner in studies of the downstream effects of reservoir management (Actions 23 and 24, 29 and 30, 36, and 42).

U.S. Geological Survey-At present, the primary involvement of the USGS in routine monitoring in the study area is the operation of one gaging station at the Deschutes River near Culver (fig. 3). Most other gages are operated by OWRD. The USGS could most effectively contribute to water-quality monitoring in the Deschutes River Basin by providing input on protocol development or quality assurance, or designing and conducting selected special studies in cooperation with local agencies and (or) the monitoring committee.

\subsection{Phased Implementation of Monitoring Actions}

A phased approach to initiate the suggested monitoring actions is proposed below. Allocation of these monitoring actions into individual phases 
would be dependent on a combination of funding, agency priorities or mandates, and the importance of the individual issue regionally. Each phase would build upon the previous one, although some programs, especially the larger special studies, might extend into subsequent phases. Descriptions of the possible phases are as follows:

Phase 1 would focus primarily on program management and implementation, including the creation of institutional agreements. It might involve actions that could be done principally within the auspices of the individual organizations and with existing resources. No changes to current monitoring programs would be made, but compilation of datasets among agencies and analysis of quality- assurance data in preparation of data analysis in Phase 2 could be initiated.

Phase 2 would include minor modifications to existing monitoring programs and the analysis of data compiled in the previous phase. Other actions would be initiated on which future monitoring will depend. Critical special studies to fill data gaps, or those that would provide data to support important programs (such as allocation of TMDL), would also be initiated.

Phase 3 would mark the beginning of more substantial modifications to existing programs, such as addition or relocation of monitoring sites. It would also include special studies to evaluate land use or resource management or that target important resource issues. By the end of this phase much of the monitoring plan would have been implemented.

Phase 4 would include the largest changes to existing programs, along with actions on issues deemed less important regionally or that are relatively expensive.

An example of the phased approach for the suggested monitoring actions is shown in table 1. The final decisions on phasing of monitoring actions and the priority or order of implementation are beyond the scope of this report. Furthermore, the items scheduled to be initiated in each phase could change as the plan is reevaluated periodically and local issues change in importance. This is particularly true for the latter phases because the results from earlier phases could cause shifts in the understanding and priority of different issues.

\subsection{References}

1. American Public Health Association, 1985, Standard methods for the examination of water and wastewater, 16th Edition: Washington, D.C., American Public Health Association.

2. Anderson, C.W., and Carpenter, K.D., 1998, Water quality and algal conditions in the North Umpqua River Basin, Oregon, 1992-95, and implications for resource management: U.S. Geological Survey Water-Resources Investigations Report 98-4125, 78 p., 1 pl.

3. Bauer, S.B., and Ralph, S.C., 1999, Aquatic habitat indicators and their application to water quality objectives within the Clean Water ActExecutive Summary: Seattle, Washington, US Environmental Protection Agency, Region 10, EPA 910-R-99-014, 8 p.

4. Bothwell, M.L., 1992, Eutrophication of rivers by nutrients in treated kraft pulp mill effluent: Canadian Journal of Water Pollution Research, v. 27, no. 3, p. 447-472.

5. Caldwell, R.R., 1998, Chemical study of regional ground-water flow and ground-water/surfacewater interaction in the upper Deschutes River Basin, Oregon: U.S. Geological Survey Water Resources Investigations Report 97-4233, 49 p., $1 \mathrm{pl}$.

6. Cameron, K.A., and Major, J.J., 1987, Reconnaissance investigation of sediment distribution, erosion, and transport in the upper Deschutes River, Deschutes County, Oregon, November 1986: Water-Resources Investigations Report 87-4114, 24 p.

7. Columbia River Inter-Tribal Fish Commission, 1996, Wy-kan-us-mi Wa-kish-wit: The Columbia River anadromous fish restoration plan of the Nez Perce, Umatilla, Warm Springs, and Yakima tribes-Volume I: Portland, Oregon, Columbia River Inter-Tribal Fish Commission, variously paged.

8. Deschutes County Development Department, 2000, La Pine National On-site Demonstration Project: Environmental Health Division web page, url <http://newberry.deschutes.org/cddweb/ envhealth/envhealth.htm>, accessed April 2000.

9. Dixit, S.S., Smol, J.P., Charles, D.F., Hughes, R.M., Paulsen, S.G., and Collins, G.B., 1999, Assessing water quality changes in the lakes of the northeastern United States using sediment 
diatoms: Canadian Journal of Fisheries and Aquatic Sciences, v. 56, p. 131-152.

10. Dodds, W.K., Smith, V.H., and Zander, B., 1997, Developing nutrient targets to control benthic chlorophyll levels in streams: Water Research, v. 31 , no. 7, p. 1738-1750.

11. E\&S Environmental Chemistry, 1997, Limnology of Lake Billy Chinook and Lake Simtustus, Oregon: Corvallis, E\&S Environmental Chemistry, Pelton Round Butte Limnology Study Project Number 2030, Final Report, variously paged.

12. Edwards, T.K., and Glysson, D.G., 1999, Field methods for measurement of fluvial sediment: Techniques of Water-Resources Investigations of the U.S. Geological Survey, Book 3, Chapter C2, $89 \mathrm{p}$.

13. Gannett, M.W. , Lite, K.E., Morgan, D.S. , and Collins, C.A., in press, Ground-Water Hydrology of the Upper Deschutes Basin, Oregon: U.S. Geological Survey Water-Resources Investigations Report 00-4162.

14. Gray, J.R., Glysson, G.D., Turcios, L.M., and Schwarz, G.E., 2000, Comparability of suspended-sediment concentration and total suspended solids data: U.S. Geological Survey Water-Resources Investigations Report 00-4191, $20 \mathrm{p}$.

15. Guasch, H., Armengol, J., Marti, E., and Sabater, S., 1998, Diurnal variation in dissolved oxygen and carbon dioxide in two low-order streams: Water Research, v. 32, no. 4, p. 1067-1074.

16. Hankin, D.G., and Reeves, G.H., 1988, Estimating total fish abundance and total habitat area in small streams based on visual estimation methods: Canadian Journal of Fisheries and Aquatic Sciences, v. 45, p. 834-844.

17. Harrelson, C.C., Rawlins, C.L., and Potyondy, J.P., 1994, Stream channel reference sites-An illustrated guide to field technique: Fort Collins, Colorado, U.S. Department of Agriculture. Forest Service, General Technical Report RM-245, 61 p.

18. Horowitz, A.J., Demas, C.R., Fitzgerald, K.K., Miller, T.M., and Rickert, D.A., 1994, U.S. Geological Survey protocol for the collection and processing of surface-water samples for the subsequent determination of inorganic substances in filtered water: U.S. Geological Survey OpenFile Report 94-539, 57 p.

19. Houslet, B., 1998, Temperature modeling of Squaw Creek from the Squaw Creek Irrigation District dam to the Crooked River Grasslands: Sisters,
Oregon, U.S. Department of Agriculture, Forest Service, Sisters Ranger District, 9 p.

20. Interorganizational Resource Information Coordinating Council, 1999, Clarification and update to Phase I common data standards for aquatic inventory and stream identification: Report of the Interorganizational Resource Information Coordinating Council Fish Hydrography Strike Team, Revised May 1999, Accessed on Bureau of Land Management Intranet at http://web.or.blm.gov/or930/ on December 1, 1999, $51 \mathrm{p}$.

21. Johnson, D. M., Petersen, R.P., Lycan, D.R. Sweet, J.W., Neuhaus, M.E., and Schaedel, A.L., 1985, Atlas of Oregon lakes: Corvallis, Oregon State University Press, 317 p.

22. Joy, J., and Patterson, B., 1997, A suspended sediment and DDT total maximum daily load evaluation report for the Yakima River: Washington Department of Ecology, Publication No. 97-321, 105 p.

23. Krabbenhoft, D.P., and Rickert, D.A., 1995, Mercury contamination of aquatic ecosystems: U.S. Geological Survey Fact Sheet FS-216-95, $4 \mathrm{p}$.

24. Lowe, R.L., and Pan, Y., 1996, Benthic algal communities as biological monitors, in Stevenson, J.R., Bothwell, M.L., and Lowe, R.L., eds., Algal ecology, freshwater benthic ecosystems: San Diego, California, Academic Press, Inc., p. 705-739.

25. Lower Columbia River Estuary Program, 1998, Lower Columbia River Estuary Plan-Volume 2-Aquatic ecosystem monitoring strategy for the lower Columbia River, and Information Management Strategy: Portland, Oregon, Lower Columbia River Program, p. B1-B22, available at <http://www.lcrep.org/reports.htm>.

26. Lower Columbia River Estuary Program, 1999, Interagency long term monitoring plan to assess water quality, sediment quality, aquatic health, and biological integrity in the lower Columbia River: Portland, Oregon, Lower Columbia River Estuary Program, Interagency Subcommittee Report, $161 \mathrm{p}$.

27. Manga, M., 1996, Hydrology of spring dominated streams in the Oregon Cascades: Water Resources Research, v. 32, no. 8, p. 2435-2439.

28. Manga, M., 1997, A model for discharge in springdominated streams and implications for the transmissivity and recharges of quaternary 
volcanics in the Oregon Cascades: Water

Resources Research, v. 33, no. 8, p. 1813-1822.

29. Marzolf, E.R., Mulholland, P.J., and Steinman, A.D., 1994, Improvements to the diurnal upstream-downstream dissolved oxygen change technique for determining whole-stream metabolism in small streams: Canadian Journal of Fisheries and Aquatic Sciences, v. 51, no. 15911599.

30. Marzolf, E.R., Mulholland, P.J., and Steinman, A.D., 1998, Reply: Improvements to the diurnal upstream-downstream dissolved oxygen change technique for determining whole-stream metabolism in small streams: Canadian Journal of Fisheries and Aquatic Sciences, v. 55, p. 17861787.

31. Moffat, R.L., Wellman, R.E., and Gordon, J.M., 1990, Statistical summaries of streamflow data in Oregon: Volume 1-Monthly and annual streamflow, and flow-duration values: U.S. Geological Survey Open-File Report 90-118, $413 \mathrm{p}$.

32. Morgan, D.S., Tanner, D.Q., and Crumrine, M. D., 1997, Hydrologic and water-quality conditions at Newberry Volcano, Deschutes County, Oregon, 1991-95: U.S. Geological Survey WaterResources Investigations Report 97-4088, 66 p.

33. Odum, H.T., 1956, Primary production in flowing waters: Limnology and Oceano-graphy, v. 1., no 2., p. 102-117

34. Oregon Department of Environmental Quality, 1988, 1988 Oregon assessment of nonpoint source water pollution: Portland, Oregon Department of Environmental Quality, 182 p., appendixes.

35. Oregon Department of Environmental Quality, 1994, DEQ laboratory field sampling reference guide, revision 4.0: Portland, Oregon Department of Environmental Quality Laboratory, 76 p.

36. Oregon Department of Environmental Quality, 1995, Coast Fork TMDL Development: Portland, Oregon Department of Environmental Quality, variously paged.

37. Oregon Department of Environmental Quality, 1996, Mercury in Oregon Lakes, 1993-1994: Portland, Oregon Depart-ment of Environmental Quality, variously paged.

38. Oregon Department of Environmental Quality, 1999a, Water Quality Limited Streams 303(d) List Web page: <http:// waterquality.deq.state.or.us/wq/303dlist/ 303dpage.htm>, accessed November 1999.

39. Oregon Department of Environmental Quality, 1999b, WQ Facility Information System Web page: <http://waterquality.deq.state.or.us/ SISData/FacilityHome.asp>, accessed November 1999.

40. Oregon Department of Environmental Quality, 1999c, Listing criteria for Oregon's 1998 303(d) list of water quality limited water bodies: <http:// waterquality.deq.state.or.us/WQLData/ ListingCriteria.htm>, accessed December 1999.

41. Oregon Department of Environmental Quality, 1999d, Oregon Water Quality Index for the Deschutes River Basin Web page: <http:// www.deq.state.or.us/lab/WQM/WQI/deschood/ deshood3.htm>, accessed December 1999.

42. Oregon Department of Environmental Quality, 1999e, Upper Deschutes River Basin R-EMAP: 1997-1998 Water Chemistry Summary: Portland, Oregon Department of Environmental Quality, Laboratory Division, Technical Report BIO9904, $29 \mathrm{p}$.

43. Oregon Department of Environmental Quality, 2000a, Upper Grande Ronde River Sub-basin Total Maximum Daily Load (TMDL) and Water Quality Management Plan (WQMP): Portland, Oregon Department of Environmental Quality, available online at url <http:// waterquality.deq.state.or.us/wq/TMDLs/ TMDLs.htm>, 65 p. plus appendixes.

44. Oregon Department of Environmental Quality, 2000b, La Pine National Demonstration Project Web page: <http://waterquality.deq.state.or.us/ wq/OnSite/LaPine.htm>, accessed April, 2000.

45. Oregon Department of Fish and Wildlife, 1996, Upper Deschutes River Fish Management Plan: Portland, Oregon Department of Fish and Wildlife, 1996, $385 \mathrm{p}$.

46. Oregon Department of Fish and Wildlife, 1999, Oregon Wildlife Diversity Plan: Salem, Oregon Department of Fish and Wildlife, variously paged.

47. Pacific Northwest Ecosystem Research Consortium, 1998, Willamette River Basin-A planning atlas, version 1.0: Corvallis, Oregon State University Institute for Sustainable Development, $72 \mathrm{p}$.

48. Paerl, H.W., and Downs, M. T., 1978, Biological availability of low versus high molecular weight reactive phosphorus: Journal of the Fisheries Research Board of Canada, v. 35, p. 1639-1643. 
49. Pogue, T.R., and Anderson, C.W., 1995, Processes controlling dissolved oxygen and $\mathrm{pH}$ in the Upper Willamette River Basin, Oregon, 1994: U.S. Geological Survey Water-Resources Investigations Report 95-4205, 71 p.

50. Roper, B.B., and Scarnecchia, D.L., 1995, Observer variability in classifying habitat types in stream surveys: American Journal of Fisheries Management, v. 15, p. 49-53.

51. San Francisco Estuary Project, 1993, Regional Monitoring Strategy: Oakland, California, 44 p., 3 appendixes.

52. Seiler, R.L., Zaugg, S.D., Thomas, J.M., and Howcroft, D.L., 1999, Caffeine and pharmaceuticals as indicators of waste water contamination in wells: Ground Water, v. 37, no. 3 , p. $405-410$.

53. Stager, J.C., Leavitt, P.R., and Dixit, S.S., 1997, Assessing impacts of past human activity on the water quality of Upper Saranac Lake, New York: Journal of Lake and Reservoir Management, v. 13, no. 2, p. 175-184.

54. State of Oregon, 1997, Coastal Salmon Restoration Initiative-The Oregon Plan: Salem, Oregon Department of Fish and Wildlife, also available online at <http://www.oregon-plan.org/>, variously paged.

55. Tanner, D.Q., and Anderson, C.W., 1996, Assessment of water quality, nutrients, algal productivity, and management alternatives for low-flow conditions, South Umpqua River Basin, Oregon, 1990-92: U.S. Geological Survey WaterResources Investigations Report 96-4082, 71 p.

56. Triska, F.J., Sedell, J.R., Cromack, K.J., Gregory, S.V., and McCorison, F.M., 1984, Nitrogen budget for a small coniferous forest stream: Ecological Monographs, v. 54, no. 1, p. 119-140.

57. Tuchman, N., 1996, The roll of heterotrophy in algae, in Stevenson, J.R., Bothwell, M.L., and Lowe, R.L., eds., Algal ecology, freshwater benthic ecosystems: San Diego, California, Academic Press, Inc., p. 299-319.

58. U.S. Department of Agriculture, Forest Service, 1990, Land and resource management plan, Deschutes National Forest, Chapter 5Implementation of the Forest Plan: Bend, Oregon, USDA Forest Service, variously paged.

59. U.S. Department of Agriculture, Forest Service, 1991, Land and resource management plan-Part 1-Ochoco National Forest: Prineville, Oregon, U.S. Department of Agriculture, Forest Service, Pacific Northwest Region, variously paged.
60. U.S. Department of Agriculture, Forest Service, 1994, Upper Deschutes Basin instream flow assessment: Bend, U.S. Department of Agriculture Forest Service, Deschutes National Forest, $45 \mathrm{p}$.

61. U.S. Department of Agriculture, Forest Service, 1995, Inland native fish strategy, Environmental Assessment-Decision notice and finding of no significant impact. Intermountain, Northern, and Pacific Northwest Regions: Coeur d'Alene, Idaho, U..S. Department of Agriculture Forest Service, variously paged.

62. U.S. Department of Agriculture Forest Service, 1996a, Upper Deschutes Wild and Scenic River and State Scenic Waterway-Comprehensive Management Plan: Bend, Oregon, U.S. Department of Agriculture Forest Service, Deschutes National Forest, variously paged.

63. U.S. Department of Agriculture, Forest Service, 1996b, Upper Deschutes Wild and Scenic River and State Scenic Waterway-Record of Decision and Final Environmental Impact Statement: Bend, Oregon, U.S. Department of Agriculture Forest Service, Deschutes National Forest, variously paged.

64. U.S. Department of Agriculture, Forest Service, 1998, Sisters/Why-chus Watershed Analysis: Sisters, Oregon, U.S. Department of Agriculture Forest Service, Deschutes National Forest, Sisters Ranger District, variously paged.

65. U.S. Department of the Interior, Bureau of Land Management and U.S. Depart-ment of Agriculture Forest Service, 1992, Middle Deschutes/Lower Crooked Wild and Scenic Rivers' Management Plan: Prineville, Oregon, U.S. Department of the Interior Bureau of Land Management, $57 \mathrm{p}$.

66. U.S. Environmental Protection Agency, 2000, Nutrient criteria technical guidance manual: rivers and streams: U.S. Environmental Protection Agency EPA-822-D-99-003

67. Wilde, F.D., Schertz, T.L., and Radtke, D.B., 1999, Quality control samples, in National field manual for the collection of water-quality data, Wilde, F.D., Radtke, D.B., Gibs, J., and Iwatsubo, R.T. (eds.), National field manual for the collection of water-quality data, Chapter A4-Collection of water samples, U.S. Geological Survey Techniques of Water Resources Investigations, Book 9, Handbooks for Water-Resources Investigations, variously paged. 


\subsection{Glossary}

303(d) List

\section{alluvial}

baseline conditions

benthic
BLM
BOR
EPA
$f^{3} / s$
GIS
indicator reach

IRICC

LWD

$\mathrm{mg} / \mathrm{L}$

nonindigenous species

NPDES
NRIS
ODFW
ODEQ
OWRD
OWQI
PGE
QA
QC
reference conditions
run-of-the-river
TMDLs

$\mu \mathbf{m}$

USEPA

USFS

USGS
A statewide list of streams or stream reaches that do not meet water quality standards for specified constituents, and for which load allocations must be set. The list is mandated under section 303(d) of the Clean Water Act.

Describes rivers with beds and channels composed largely of clastic and detrital materials that can be transported or deposited

Conditions at some point in time from which changes can be documented. This is considered different from "Reference

Conditions", which are more related to conditions in the absence of human influence.

Of, relating to, or occurring at the bottom of a body of water

U.S. Department of Interior, Bureau of Land Management

U.S. Department of Interior, Bureau of Reclamation

U.S. Environmental Protection Agency

cubic feet per second, a measure of streamflow

Geographical Information System

A reach of river that is visited periodically in order to take samples or make measurements and for which conditions are expected to reflect those in reaches with similar structure and functioning Interorganizational Resource Information Coordinating Council Large Woody Debris

milligrams per liter (parts per million)

Species that are not native to a specified area and which often have no natural predators in that area. They can often disrupt local food chains, habitat, or resource availability.

National Pollutant Discharge Elimination System

Natural Resource Inventory System, a computer database developed by the U.S. Forest Service

Oregon Department of Fish and Wildlife

Oregon Department of Environmental Quality

Oregon Water Resources Department

Oregon's Water Quality Index, calculated from data collected by the ODEQ Ambient Monitoring Program

Portland General Electric

Quality Assurance

Quality Control

Conditions found in a given stream prior to alteration by humans Having low hydraulic retention time or pool volume

Total Maximum Daily Loads, a load allocation determined for a given constituent and stream for which water quality standards are not met. TMDLs are mandated as part of the Clean Water Act (see 303(d) list).

micrometer $\left(10^{-6}\right.$ meters $)$

U.S. Environmental Protection Agency

U.S. Forest Service

U.S. Geological Survey 

APPENDIXES 

Table A-1. Water-quality monitoring objectives and recommendations from previous management plans, by topic, and their proposed priority for coordinated longterm monitoring in the upper and middle Deschutes River Basin

[Note that proposed priorities only apply to interagency, coordinated monitoring and do not reflect the importance of a specific issue locally, or the needs of specific agencies. CRITFC, Columbia River IntertribalIntertribal Fish Commission; ODFW, Oregon Department of Fish and Wildlife; OWRD, Oregon Water Resources Department; BLM, Bureau of Land Management; USFS, U.S. Forest Service; WQ, water quality; temp., temperature; TSS, total suspended solids; turb., turbidity; LDR, Little Deschutes River; ab, above; Br, Bridge; DR, Deschutes River; blw, below; UDB, Upper Deschutes Basin; $\mathrm{ft}^{3}$ /s, cubic feet per second; IGDO, Intergravel Dissolved Oxygen; NG, None given; FREQUENCY DEFINITIONS: C, continuous; W, Weekly; Q, quarterly; A, annual; A $N$, every $N$ years; O, one time effort; E, Evaluate frequency after testing effectiveness; V, Varies according to project specific details; MONITORING TYPE DEFINITIONS: ST, Status \& Trends, CO, Compliance, EV, Evaluation; RE, Reconnaissance; <, less than; >, greater than; $\geq$, greater than or equal to; Reference number, numbered citations in Reference section]

\begin{tabular}{|c|c|c|c|c|c|c|c|}
\hline 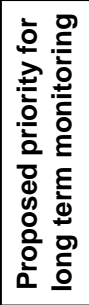 & Water issue & Entity & Monitoring objective & Recommended monitoring & 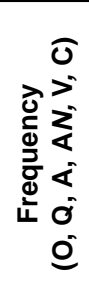 & 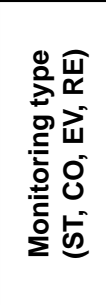 & 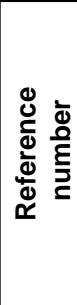 \\
\hline \multicolumn{8}{|c|}{ Water-Quantity Related Monitoring } \\
\hline $\mathrm{H}$ & Streamflow & $\begin{array}{l}\text { Forest Service, 1996, UDR } \\
\text { Comprehensive Management } \\
\text { Plan }\end{array}$ & $\begin{array}{l}\text { Correlate flows with trends in } \\
\text { resource condition }\end{array}$ & $\begin{array}{l}\text { OWRD add (?) stations below } \\
\text { reservoirs, at Benham Falls, below } \\
\text { Bend }\end{array}$ & $\mathrm{C}$ & $\begin{array}{l}\text { ST, } \\
\text { CO, }\end{array}$ & 62 \\
\hline $\mathrm{H}$ & \multirow{6}{*}{$\begin{array}{l}\text { Instream Flow- } \\
\text { Wickiup Dam to Fall River }\end{array}$} & \multirow{6}{*}{$\begin{array}{l}\text { Flow Team, 1994, UDR Instream } \\
\text { Flow Assessment }\end{array}$} & Water Quality (turbidity) & $\begin{array}{l}\text { Storage Season- } 500 \mathrm{ft}^{3} / \mathrm{s} \\
\text { Irrigation Season-< }-1,200 \mathrm{ft}^{3} / \mathrm{s} \\
\text { Enhanced Flow-600-900 ft } 3 / \mathrm{s}\end{array}$ & A & $\begin{array}{l}\mathrm{CO}, \\
\mathrm{ST}\end{array}$ & 60 \\
\hline $\mathrm{H}$ & & & Brown Trout and other fish & $\begin{array}{l}\text { Storage Season-300 } \mathrm{ft}^{3} / \mathrm{s} \\
\text { Irrigation Season-< } 1,200 \mathrm{ft}^{3} / \mathrm{s} \\
\text { Enhanced Flow - 600-900 } \mathrm{ft}^{3} / \mathrm{s}\end{array}$ & $\mathrm{A}$ & $\begin{array}{l}\mathrm{CO}, \\
\mathrm{ST}\end{array}$ & 60 \\
\hline $\mathrm{H}$ & & & Riparian vegetation & $\begin{array}{l}\text { Storage Season- } 500 \mathrm{ft}^{3} / \mathrm{s} \\
\text { Irrigation Season-< }-1,200 \mathrm{ft}^{3} / \mathrm{s} \\
\text { Enhanced Flow-600-900 ft } 3 / \mathrm{s}\end{array}$ & A & $\begin{array}{l}\mathrm{CO}, \\
\mathrm{ST}\end{array}$ & 60 \\
\hline $\mathrm{H}$ & & & Wildlife & $\begin{array}{l}\text { Storage Season- } 500 \mathrm{ft}^{3} / \mathrm{s} \\
\text { Irrigation Season-< }-1,200 \mathrm{ft}^{3} / \mathrm{s} \\
\text { Enhanced Flow-600-900 ft } 3 / \mathrm{s}\end{array}$ & $\mathrm{A}$ & $\begin{array}{l}\mathrm{CO}, \\
\mathrm{ST}\end{array}$ & 60 \\
\hline $\mathrm{H}$ & & & Scenic Value & $\begin{array}{l}\text { Storage Season- } 500 \mathrm{ft}^{3} / \mathrm{s} \\
\text { Irrigation Season-< }-1,200 \mathrm{ft}^{3} / \mathrm{s} \\
\text { Enhanced Flow-600-900 ft } 3 / \mathrm{s}\end{array}$ & $\mathrm{A}$ & $\begin{array}{l}\mathrm{CO}, \\
\mathrm{ST}\end{array}$ & 60 \\
\hline $\mathrm{H}$ & & & Recreation & $\begin{array}{l}\text { Storage Season-250 } \mathrm{ft}^{3} / \mathrm{s} \\
\text { Irrigation Season-< }<1,150 \mathrm{ft}^{3} / \mathrm{s} \\
\text { Enhanced Flow } \\
\quad \text { canoeing-600-800 } \mathrm{ft}^{3} / \mathrm{s} \\
\text { rafting-100-1,300 } \mathrm{ft}^{3} / \mathrm{s}\end{array}$ & $\mathrm{A}$ & $\begin{array}{l}\mathrm{CO}, \\
\mathrm{ST}\end{array}$ & 60 \\
\hline \multicolumn{8}{|c|}{ General Water-Quality Issues } \\
\hline $\mathrm{H}$ & $\begin{array}{l}\text { Critical WQ Parameters } \\
\text { (Temp., DO, pH, TSS, turbidity) }\end{array}$ & $\begin{array}{l}\text { Forest Service, 1996, UDR } \\
\text { Comprehensive Management } \\
\text { Plan }\end{array}$ & $\begin{array}{l}\text { Determine trends resulting } \\
\text { from management actions and } \\
\text { other changes within the river } \\
\text { corridor }\end{array}$ & $\begin{array}{l}\text { DEQ monitor WQ at ambient } \\
\text { monitoring sites, including } 2 \text { new sites } \\
\text { (LDR ab. Harper Br. \& DR blw. } \\
\text { Wickiup) }\end{array}$ & Q & $\begin{array}{l}\text { ST, } \\
\text { EV, } \\
\text { CO }\end{array}$ & 62 \\
\hline
\end{tabular}


Table A-1. Water-quality monitoring objectives and recommendations from previous management plans, by topic, and their proposed priority for coordinated longterm monitoring in the upper and middle Deschutes River Basin-Continued

[Note that proposed priorities only apply to interagency, coordinated monitoring and do not reflect the importance of a specific issue locally, or the needs of specific agencies. CRITFC, Columbia River IntertribalIntertribal Fish Commission; ODFW, Oregon Department of Fish and Wildlife; OWRD, Oregon Water Resources Department; BLM, Bureau of Land Management; USFS, U.S. Forest Service; WQ, water quality; temp., temperature; TSS, total suspended solids; turb., turbidity; LDR, Little Deschutes River; ab, above; Br, Bridge; DR, Deschutes River; blw, below; UDB, Upper Deschutes Basin; $\mathrm{ft} \%$ s, cubic feet per second; IGDO, Intergravel Dissolved Oxygen; NG, None given; FREQUENCY DEFINITIONS: C, continuous; W, Weekly; Q, quarterly; A, annual; AN, every $N$ years; O, one time effort; E, Evaluate frequency after testing effectiveness; V, Varies according to project specific details; MONITORING TYPE DEFINITIONS: ST, Status \& Trends, CO, Compliance, EV, Evaluation; RE, Reconnaissance; <, less than; >, greater than; $\geq$, greater than or equal to; Reference number, numbered citations in Reference section]

\begin{tabular}{|c|c|c|c|c|c|c|c|}
\hline 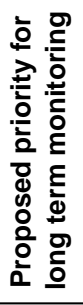 & Water issue & Entity & Monitoring objective & Recommended monitoring & 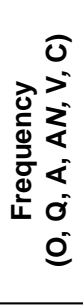 & 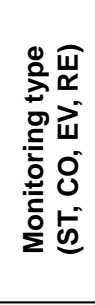 & 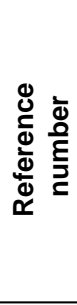 \\
\hline \multicolumn{8}{|c|}{ General Water-Quality Issues_Continued } \\
\hline$L^{d}$ & Water Temperature & $\begin{array}{l}\text { Forest Service, 1990, Land \& } \\
\text { Resource Management Plan, } \\
\text { Deschutes National Forest }\end{array}$ & $\begin{array}{l}\text { Increases from management } \\
\text { kept within desired range of a } \\
\text { benefiting resource (fish, water } \\
\text { supply) }\end{array}$ & $\begin{array}{l}\text { Monitor for specific projects, for at } \\
\text { least } 1 \text { year before and } 3 \text { years after } \\
\text { project completion. }\end{array}$ & $\mathrm{A}$ & $\begin{array}{l}\mathrm{CO}, \\
\mathrm{EV}\end{array}$ & 58 \\
\hline $\mathrm{H}$ & Fecal Coliform ${ }^{a}$ & \multirow{5}{*}{$\begin{array}{l}\text { BLM and Forest Service, } 1992, \\
\text { Middle Deschutes/Lower } \\
\text { Crooked Management Plan }\end{array}$} & \multirow{5}{*}{$\begin{array}{l}\text { Maintain State water-quality } \\
\text { standards b,c }\end{array}$} & $\begin{array}{l}\text { Take grab samples during spring, } \\
\text { summer, and fall }\end{array}$ & $\mathrm{A}$ & $\mathrm{CO}$ & 65 \\
\hline $\mathrm{H}$ & Temperaturea & & & Monitor temperature continuously & $\mathrm{C}$ & $\mathrm{CO}$ & 65 \\
\hline $\mathrm{H}$ & Turbidity & & & $\begin{array}{l}\text { Monitor with autosamplers during } \\
\text { flushing flows in fall, winter, and } \\
\text { spring, + during June-August }\end{array}$ & $\mathrm{A}$ & $\mathrm{CO}$ & 65 \\
\hline $\mathrm{H}$ & $\mathrm{pH}$ & & & $\begin{array}{l}\text { Monitor with autosampler, use same } \\
\text { frequency as for turbidity }\end{array}$ & $\mathrm{A}$ & $\mathrm{CO}$ & 65 \\
\hline $\mathrm{H}$ & Dissolved Oxygen & & & $\begin{array}{l}\text { Monitor with autosampler } \\
\text { (during summer) }\end{array}$ & $\mathrm{W}$ & $\mathrm{CO}$ & 65 \\
\hline $\mathrm{H}$ & $\begin{array}{l}\text { Water Quality- } \\
\text { Water Temperature }\end{array}$ & $\begin{array}{l}\text { CRITFC, 1996, Columbia } \\
\text { River anadromous fish } \\
\text { restoration plan }\end{array}$ & $\begin{array}{l}\text { Maintain maximum daily water } \\
\text { temperature }>60 \mathrm{deg} . \\
\text { Fahrenheit. }^{\text {a }}\end{array}$ & NG & NG & $\begin{array}{l}\mathrm{EV} \\
\mathrm{CO}\end{array}$ & 7 \\
\hline $\mathrm{H}$ & $\begin{array}{l}\text { Water Quality- } \\
\text { Miscellaneous Pollutants }\end{array}$ & $\begin{array}{l}\text { CRITFC, 1996, Columbia } \\
\text { River anadromous fish } \\
\text { restoration plan }\end{array}$ & $\begin{array}{l}\text { Maintain WQ to meet current } \\
\text { WQ standards. Review and } \\
\text { revise current state and federal } \\
\text { WQ standards to adequately } \\
\text { protect salmon. }\end{array}$ & $\begin{array}{l}\text { Monitor WQ parameters for which } \\
\text { there are standards (temperature, DO, } \\
\text { pH, turbidity, bacteria), where there is } \\
\text { potential for pollution. }\end{array}$ & NG & $\begin{array}{l}\mathrm{EV}, \\
\mathrm{CO}\end{array}$ & 7 \\
\hline $\mathrm{H}$ & $\begin{array}{l}\text { Water Quality- } \\
\text { Riparian Reserves }\end{array}$ & $\begin{array}{l}\text { CRITFC, 1996, Columbia R. } \\
\text { anadromous fish restoration } \\
\text { plan }\end{array}$ & $\begin{array}{l}\text { Maintain riparian reserves } \geq \\
300 \mathrm{ft} \text { slope distance from } \\
\text { floodplains or to topographic } \\
\text { divide (whichever is less) }\end{array}$ & Monitor water temperature & NG & $\begin{array}{l}\mathrm{EV}, \\
\mathrm{CO}\end{array}$ & 7 \\
\hline
\end{tabular}


Table A-1. Water-quality monitoring objectives and recommendations from previous management plans, by topic, and their proposed priority for coordinated longterm monitoring in the upper and middle Deschutes River Basin-Continued

[Note that proposed priorities only apply to interagency, coordinated monitoring and do not reflect the importance of a specific issue locally, or the needs of specific agencies. CRITFC, Columbia River IntertribalIntertribal Fish Commission; ODFW, Oregon Department of Fish and Wildlife; OWRD, Oregon Water Resources Department; BLM, Bureau of Land Management; USFS, U.S. Forest Service; WQ, water quality; temp., temperature; TSS, total suspended solids; turb., turbidity; LDR, Little Deschutes River; ab, above; Br, Bridge; DR, Deschutes River; blw, below; UDB, Upper Deschutes Basin; $\mathrm{ft}^{3}$ /s, cubic feet per second; IGDO, Intergravel Dissolved Oxygen; NG, None given; FREQUENCY DEFINITIONS: C, continuous; W, Weekly; Q, quarterly; A, annual; AN, every $N$ years; O, one time effort; E, Evaluate frequency after testing effectiveness; V, Varies according to project specific details; MONITORING TYPE DEFINITIONS: ST, Status \& Trends, CO, Compliance, EV, Evaluation; RE, Reconnaissance; <, less than; >, greater than; $\geq$, greater than or equal to; Reference number, numbered citations in Reference section]

\begin{tabular}{|c|c|c|c|c|c|c|c|}
\hline 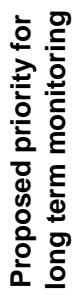 & Water issue & Entity & Monitoring objective & Recommended monitoring & 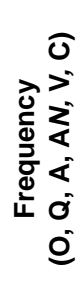 & 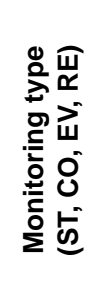 & 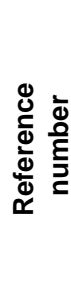 \\
\hline \multicolumn{8}{|c|}{ General Water-Quality Issues-Continued } \\
\hline$L^{d}$ & $\begin{array}{l}\text { TMDLs, 303(d) planning } \\
\text { in Squaw Creek }\end{array}$ & \begin{tabular}{|l} 
Forest Service, 1998, Sisters \\
Why-chus Watershed Analysis
\end{tabular} & $\begin{array}{l}\text { Improve fish \& aquatic habitat } \\
\text { and riparian vegetation by } \\
\text { increasing summer flows }\end{array}$ & $\begin{array}{l}\text { Monitor temperature, DO, and } \\
\text { discharge }\end{array}$ & NG & EV & 64 \\
\hline$L^{d}$ & $\begin{array}{l}\text { Rehabilitation of specific } \\
\text { locations in Squaw Creek } \\
\text { Basin (Pole Creek, Trout Creek, } \\
\text { Three Creeks, Indian Ford Creek) }\end{array}$ & $\begin{array}{l}\text { Forest Service, 1998, Sisters } \\
\text { Why-chus Watershed Analysis }\end{array}$ & $\begin{array}{l}\text { Improve soil moisture, reduce } \\
\text { erosion, increase riparian } \\
\text { vegetation, and increase habitat } \\
\text { by increasing discharge }\end{array}$ & $\begin{array}{l}\text { Monitor temperature and flows in } \\
\text { Squaw Creek, conduct erosion surveys } \\
\text { using photography }\end{array}$ & NG & $\mathrm{EV}$ & 64 \\
\hline \multicolumn{8}{|c|}{ Turbidity-related Monitoring } \\
\hline $\mathrm{H}$ & $\begin{array}{l}\text { Turbidity, Fish Stranding } \\
\text { associated with ramping }\end{array}$ & $\begin{array}{l}\text { Forest Service, 1996, UDR } \\
\text { Comprehensive Management } \\
\text { Plan }\end{array}$ & $\begin{array}{l}\text { Determine effect of } \\
\text { experimental ramping rate } \\
\text { changes }\end{array}$ & $\begin{array}{l}\text { ODFW \& USFS measure turbidity in } \\
\text { releases below Wickiup from spring } \\
\text { until flows reach } 1,800 \mathrm{ft}^{3} / \mathrm{s} \text {. Evaluate } \\
\text { usefulness }\end{array}$ & A & $\begin{array}{l}\text { RE, } \\
\text { EV }\end{array}$ & 62 \\
\hline \multicolumn{8}{|c|}{ Channel Morphology and Habitat Related Monitoring } \\
\hline M & Channel Morphology & $\begin{array}{l}\text { Forest Service, 1996, UDR } \\
\text { Comprehensive Management } \\
\text { Plan }\end{array}$ & $\begin{array}{l}\text { Determine long term trends in } \\
\text { morphology and instream flow } \\
\text { levels }\end{array}$ & $\begin{array}{l}\text { ODFW \& USFS do cross sectional } \\
\text { profiles at ITFM sites; use aerial photos } \\
\text { for large-scale changes }\end{array}$ & A5 & $\begin{array}{l}\text { ST, } \\
\text { EV, }\end{array}$ & 62 \\
\hline M & $\begin{array}{l}\text { Changes in Channel } \\
\text { Morphology and } \\
\text { Hydrologic Condition }\end{array}$ & $\begin{array}{l}\text { Forest Service, 1996, UDR } \\
\text { Comprehensive Management } \\
\text { Plan }\end{array}$ & $\begin{array}{l}\text { Determine effectiveness of fish } \\
\text { habitat projects }\end{array}$ & $\begin{array}{l}\text { USFS, ODFW measure cross sectional } \\
\text { profiles at } 2 \text { sites within each project } \\
\text { area (?) }\end{array}$ & $\begin{array}{l}\mathrm{O}, \\
\mathrm{A} 5\end{array}$ & $\begin{array}{l}\mathrm{RE}, \\
\mathrm{EV}\end{array}$ & 62 \\
\hline$L^{d}$ & $\begin{array}{l}\text { Channel Morphology } \\
\text { and Low Flows }\end{array}$ & $\begin{array}{l}\text { Forest Service, } 1990, \text { Land \& } \\
\text { Res. Management Plan, } \\
\text { Deschutes National Forest }\end{array}$ & $\begin{array}{l}\text { Maintain no changes in } \\
\text { channel structure or reductions } \\
\text { in low flows resulting from } \\
\text { management actions }\end{array}$ & $\begin{array}{l}\text { Measure channel profiles and low flows } \\
\text { on indicator streams and river segments }\end{array}$ & A2 & $\begin{array}{l}\mathrm{CO}, \\
\mathrm{EV}\end{array}$ & 58 \\
\hline M & $\begin{array}{l}\text { Channel Morphology- } \\
\text { Large Woody Debris (LWD) }\end{array}$ & $\begin{array}{l}\text { CRITFC, 1996, Columbia R. } \\
\text { anadromous fish restoration } \\
\text { plan }\end{array}$ & $\begin{array}{l}\text { Maintain according to land } \\
\text { management standards (no } \\
\text { numeric standard) }\end{array}$ & Monitor LWD & NG & $\begin{array}{l}\mathrm{EV}, \\
\mathrm{CO}\end{array}$ & 7 \\
\hline
\end{tabular}


Table A-1. Water-quality monitoring objectives and recommendations from previous management plans, by topic, and their proposed priority for coordinated longterm monitoring in the upper and middle Deschutes River Basin-Continued

[Note that proposed priorities only apply to interagency, coordinated monitoring and do not reflect the importance of a specific issue locally, or the needs of specific agencies. CRITFC, Columbia River IntertribalIntertribal Fish Commission; ODFW, Oregon Department of Fish and Wildlife; OWRD, Oregon Water Resources Department; BLM, Bureau of Land Management; USFS, U.S. Forest Service; WQ, water quality; temp., temperature; TSS, total suspended solids; turb., turbidity; LDR, Little Deschutes River; ab, above; Br, Bridge; DR, Deschutes River; blw, below; UDB, Upper Deschutes Basin; $\mathrm{ft}^{3}$ /s, cubic feet per second; IGDO, Intergravel Dissolved Oxygen; NG, None given; FREQUENCY DEFINITIONS: C, continuous; W, Weekly; Q, quarterly; A, annual; AN, every $N$ years; O, one time effort; E, Evaluate frequency after testing effectiveness; V, Varies according to project specific details; MONITORING TYPE DEFINITIONS: ST, Status \& Trends, CO, Compliance, EV, Evaluation; RE, Reconnaissance; <, less than; >, greater than; $\geq$, greater than or equal to; Reference number, numbered citations in Reference section]

\begin{tabular}{|c|c|c|c|c|c|c|c|}
\hline 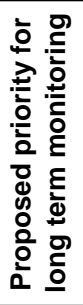 & Water issue & Entity & Monitoring objective & Recommended monitoring & 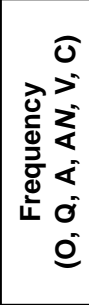 & 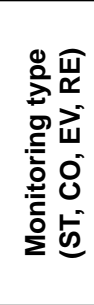 & 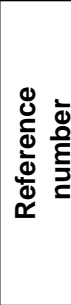 \\
\hline \multicolumn{8}{|c|}{ Channel Morphology and Habitat Related Monitoring-Continued } \\
\hline $\mathrm{M}$ & $\begin{array}{l}\text { Channel Morphology- } \\
\text { Pool frequency and volume }\end{array}$ & $\begin{array}{l}\text { CRITFC, 1996, Columbia R. } \\
\text { anadromous fish restoration } \\
\text { plan }\end{array}$ & $\begin{array}{l}\text { Maintain according to land } \\
\text { management standards (no } \\
\text { numeric standard) }\end{array}$ & NG & NG & $\begin{array}{l}\mathrm{EV}, \\
\mathrm{CO}\end{array}$ & 7 \\
\hline $\mathrm{M}$ & $\begin{array}{l}\text { Channel Morphology- } \\
\text { Residual Pool Volume }\end{array}$ & $\begin{array}{l}\text { CRITFC, 1996, Columbia R. } \\
\text { anadromous fish restoration } \\
\text { plan }\end{array}$ & $\begin{array}{l}\text { Achieve increasing trend in } \\
\text { residual pool volume (no } \\
\text { numeric standard) }\end{array}$ & NG & NG & $\begin{array}{l}\mathrm{EV} \\
\mathrm{CO}\end{array}$ & 7 \\
\hline M & $\begin{array}{l}\text { Channel Morphology- } \\
\text { Bank Stability }\end{array}$ & $\begin{array}{l}\text { CRITFC, 1996, Columbia R. } \\
\text { anadromous fish restoration } \\
\text { plan }\end{array}$ & $\begin{array}{l}\text { Maintain } \geq 90 \text { percent stability, } \\
\text { no decrease in bank stability } \\
\text { when }>90 \text { percent. Do not } \\
\text { mechanically stabilize banks } \\
\text { (e.g. riprap). }\end{array}$ & NG & NG & $\begin{array}{l}\mathrm{EV}, \\
\mathrm{CO}\end{array}$ & 7 \\
\hline$L^{d}$ & $\begin{array}{l}\text { Stream Morphology- } \\
\text { Bank Stability, Squaw Creek }\end{array}$ & $\begin{array}{l}\text { Forest Service, 1998, Sisters } \\
\text { Why-chus Watershed Analysis }\end{array}$ & $\begin{array}{l}\text { Maintain stream bank stability, } \\
\text { limit down cutting, and } \\
\text { increase scouring of historic } \\
\text { floodplains for regeneration of } \\
\text { native vegetation by allowing } \\
\text { more flooding }\end{array}$ & $\begin{array}{l}\text { Survey streams for percent of stable } \\
\text { and unstable banks }\end{array}$ & NG & EV & 64 \\
\hline M & $\begin{array}{l}\text { Channel Substrate- } \\
\text { Fine sediment in spawning gravel }\end{array}$ & $\begin{array}{l}\text { CRITFC, 1996, Columbia R. } \\
\text { anadromous fish restoration } \\
\text { plan }\end{array}$ & $\begin{array}{l}\text { Monitor to depth of egg } \\
\text { deposition. No numerical } \\
\text { standard. }\end{array}$ & NG & NG & $\begin{array}{l}\mathrm{EV} \\
\mathrm{CO}\end{array}$ & 7 \\
\hline M & \multirow[t]{2}{*}{$\begin{array}{l}\text { Channel Substrate- } \\
\text { Fine surface sediment }\end{array}$} & \multirow{2}{*}{$\begin{array}{l}\text { CRITFC, 1996, Columbia R. } \\
\text { anadromous fish restoration } \\
\text { plan }\end{array}$} & $\begin{array}{l}\text { Maintain surface area of } \\
\text { sediment covered by fine } \\
\text { sediment } \leq 20 \text { percent in } \\
\text { spawning habitat; no increase } \\
\text { where already } \geq 20 \text { percen } \tau\end{array}$ & NG & $\mathrm{NG}$ & $\begin{array}{l}\mathrm{EV}, \\
\mathrm{CO}\end{array}$ & 7 \\
\hline $\mathrm{H}$ & & & $\begin{array}{l}\text { Maintain fine sediment } \\
\text { delivery } \leq 20 \text { percent over } \\
\text { natural }\end{array}$ & NG & NG & $\begin{array}{l}\mathrm{EV}, \\
\mathrm{CO}\end{array}$ & 7 \\
\hline
\end{tabular}


Table A-1. Water-quality monitoring objectives and recommendations from previous management plans, by topic, and their proposed priority for coordinated longterm monitoring in the upper and middle Deschutes River Basin-Continued

[Note that proposed priorities only apply to interagency, coordinated monitoring and do not reflect the importance of a specific issue locally, or the needs of specific agencies. CRITFC, Columbia River IntertribalIntertribal Fish Commission; ODFW, Oregon Department of Fish and Wildlife; OWRD, Oregon Water Resources Department; BLM, Bureau of Land Management; USFS, U.S. Forest Service; WQ, water quality; temp., temperature; TSS, total suspended solids; turb., turbidity; LDR, Little Deschutes River; ab, above; Br, Bridge; DR, Deschutes River; blw, below; UDB, Upper Deschutes Basin; $\mathrm{ft}^{3} / \mathrm{s}$, cubic feet per second; IGDO, Intergravel Dissolved Oxygen; NG, None given; FREQUENCY DEFINITIONS: C, continuous; W, Weekly; Q, quarterly; A, annual; AN, every $N$ years; O, one time effort; E, Evaluate frequency after testing effectiveness; V, Varies according to project specific details; MONITORING TYPE DEFINITIONS: ST, Status \& Trends, CO, Compliance, EV, Evaluation; RE, Reconnaissance; <, less than; >, greater than; $\geq$, greater than or equal to; Reference number, numbered citations in Reference section]

\begin{tabular}{|c|c|c|c|c|c|c|c|}
\hline 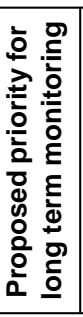 & Water issue & Entity & Monitoring objective & Recommended monitoring & 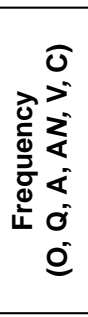 & 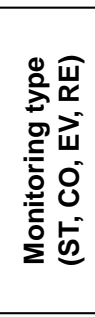 & 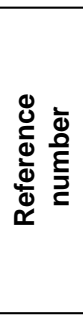 \\
\hline \multicolumn{8}{|c|}{ Channel Morphology and Habitat Related Monitoring-Continued } \\
\hline $\mathrm{M}$ & $\begin{array}{l}\text { Fish Habitat- } \\
\text { Sedimentation }\end{array}$ & $\begin{array}{l}\text { Forest Service, 1990, Land \& } \\
\text { Resource Management Plan, } \\
\text { Deschutes National Forest }\end{array}$ & $\begin{array}{l}\text { Maintain indicator segments of } \\
\text { streams having spawning and } \\
\text { rearing habitat }^{\mathrm{e}}\end{array}$ & $\begin{array}{l}\text { Conduct assessments of sediment and } \\
\text { emergence success }\end{array}$ & A2 & $\begin{array}{l}\mathrm{CO} \\
\mathrm{EV}\end{array}$ & 58 \\
\hline $\mathrm{M}$ & $\begin{array}{l}\text { Spawning Gravel } \\
\text { condition and use }\end{array}$ & $\begin{array}{l}\text { Forest Service, 1996, UDR } \\
\text { Comprehensive Management } \\
\text { Plan }\end{array}$ & $\begin{array}{l}\text { Determine effectiveness of } \\
\text { artificially introducing gravel } \\
\text { and effects of management } \\
\text { actions on those gravels }\end{array}$ & $\begin{array}{l}\text { ODFW \& USFS conduct fine sediment } \\
\text { sampling and IGDO readings where } \\
\text { new gravel has been introduced }\end{array}$ & A3 & $\begin{array}{l}\mathrm{RE}, \\
\mathrm{EV}\end{array}$ & 62 \\
\hline $\mathrm{M}$ & \multirow{3}{*}{ Fish Habitat Conditions } & \multirow{3}{*}{$\begin{array}{l}\text { Forest Service, 1996, UDR } \\
\text { Comprehensive Management } \\
\text { Plan }\end{array}$} & $\begin{array}{l}\text { Determine changes in fish } \\
\text { habitat and hydrological } \\
\text { features }\end{array}$ & $\begin{array}{l}\text { ODFW \& USFS conduct stream survey } \\
\text { of entire UDB using USFS and ODFW } \\
\text { protocols }\end{array}$ & A10 & $\begin{array}{l}\text { ST, } \\
\text { EV }\end{array}$ & 62 \\
\hline $\mathrm{M}$ & & & $\begin{array}{l}\text { Determine suitability of } \\
\text { existing gravel for } \\
\text { macroinvertebrates and as } \\
\text { spawning habitat for fish }\end{array}$ & $\begin{array}{l}\text { ODFW \& USFS sample fine sediments } \\
\text { at } 3 \text { stations (Bull Bend, Besson, } \\
\text { Meadow), \& measure IGDO }\end{array}$ & A2 & $\begin{array}{l}\text { ST, } \\
\text { EV }\end{array}$ & 62 \\
\hline $\mathrm{M}$ & & & $\begin{array}{l}\text { Determine spawning and } \\
\text { incubation gravel quality }\end{array}$ & $\begin{array}{l}\text { ODFW \& USFS measure IGDO at } \\
\text { spawning areas near Wickiup, for 1- } \\
\text { year initially }\end{array}$ & $\mathrm{O}$ & $\mathrm{RE}$ & 62 \\
\hline $\mathrm{H}$ & Fish Populations & $\begin{array}{l}\text { Forest Service, 1996, UDR } \\
\text { Comprehensive Management } \\
\text { Plan }\end{array}$ & $\begin{array}{l}\text { Determine effectiveness of fish } \\
\text { habitat projects }\end{array}$ & $\begin{array}{l}\text { ODFW do redd counts, habitat } \\
\text { characterization, electroshocking }\end{array}$ & $\begin{array}{l}\mathrm{O}, \\
\mathrm{A} 1-5\end{array}$ & $\begin{array}{l}\mathrm{RE}, \\
\mathrm{EV}\end{array}$ & 62 \\
\hline $\mathrm{M}$ & \multirow{3}{*}{ Fish Habitat } & \multirow{3}{*}{$\begin{array}{l}\text { BLM and Forest Service, 1992, } \\
\text { Middle Deschutes/Lower } \\
\text { Crooked Management Plan }\end{array}$} & $\begin{array}{l}\text { Spawning Gravel-Maintain } \\
\text { quality and quantity. Use } 1993 \\
\text { data as baseline }\end{array}$ & $\begin{array}{l}\text { Measure substrate embeddedness and } \\
\text { pebble counts }\end{array}$ & $\mathrm{A}, 3^{\mathrm{f}}$ & $\mathrm{CO}$ & 65 \\
\hline $\mathrm{M}$ & & & $\begin{array}{l}\text { Rearing Habitat - Maintain } \\
\text { pool and habitat quality and } \\
\text { quantity. Use } 1993 \text { data as } \\
\text { baseline }\end{array}$ & Survey habitat & A, $3^{f}$ & $\mathrm{CO}$ & 65 \\
\hline $\mathrm{M}$ & & & $\begin{array}{l}\text { Fish Species-Maintain } \\
\text { species composition using data } \\
\text { from ODFW as baseline }\end{array}$ & $\begin{array}{l}\text { Count fish species, coordinate with } \\
\text { ODFW }\end{array}$ & $\mathrm{A}$ & $\mathrm{CO}$ & 65 \\
\hline
\end{tabular}


Table A-1. Water-quality monitoring objectives and recommendations from previous management plans, by topic, and their proposed priority for coordinated longterm monitoring in the upper and middle Deschutes River Basin-Continued

[Note that proposed priorities only apply to interagency, coordinated monitoring and do not reflect the importance of a specific issue locally, or the needs of specific agencies. CRITFC, Columbia River IntertribalIntertribal Fish Commission; ODFW, Oregon Department of Fish and Wildlife; OWRD, Oregon Water Resources Department; BLM, Bureau of Land Management; USFS, U.S. Forest Service; WQ, water quality; temp., temperature; TSS, total suspended solids; turb., turbidity; LDR, Little Deschutes River; ab, above; Br, Bridge; DR, Deschutes River; blw, below; UDB, Upper Deschutes Basin; $\mathrm{ft}^{3}$ /s, cubic feet per second; IGDO, Intergravel Dissolved Oxygen; NG, None given; FREQUENCY DEFINITIONS: C, continuous; W, Weekly; Q, quarterly; A, annual; AN, every $N$ years; O, one time effort; E, Evaluate frequency after testing effectiveness; V, Varies according to project specific details; MONITORING TYPE DEFINITIONS: ST, Status \& Trends, CO, Compliance, EV, Evaluation; RE, Reconnaissance; <, less than; >, greater than; $\geq$, greater than or equal to; Reference number, numbered citations in Reference section]

\begin{tabular}{|c|c|c|c|c|c|c|c|}
\hline 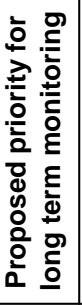 & Water issue & Entity & Monitoring objective & Recommended monitoring & 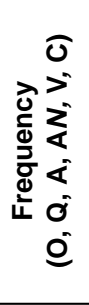 & 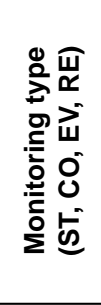 & 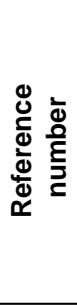 \\
\hline \multicolumn{8}{|c|}{ Channel Morphology and Habitat Related Monitoring-Continued } \\
\hline $\mathrm{L}$ & $\begin{array}{l}\text { Fish Resource and Habitat } \\
\text { - Type of Fishery and } \\
\text { Capacity }\end{array}$ & $\begin{array}{l}\text { Forest Service, 1990, Land \& } \\
\text { Resource Management Plan, } \\
\text { Deschutes National Forest }\end{array}$ & $\begin{array}{l}\text { Objectives defined variously in } \\
\text { stream, lake, and river } \\
\text { inventories and evaluations }\end{array}$ & $\begin{array}{l}\text { Conduct habitat surveys, analysis, and } \\
\text { recreational fisheries goad evaluation } \\
\text { for projects on important fish streams/ } \\
\text { lakes }^{\mathrm{g}} \text {. Use ODFW Creel surveys too. }\end{array}$ & $\mathrm{V}$ & EV & 58 \\
\hline $\mathrm{M}$ & $\begin{array}{l}\text { Fish Habitat- } \\
\text { Improvement Target }\end{array}$ & $\begin{array}{l}\text { Forest Service, 1990, Land \& } \\
\text { Resource Management Plan, } \\
\text { Deschutes National Forest }\end{array}$ & $\begin{array}{l}\text { Maintain 3-year average within } \\
25 \text { percent of target }\end{array}$ & $\begin{array}{l}\text { Compile annual accomplishment } \\
\text { reports }\end{array}$ & A & $\begin{array}{l}\mathrm{CO} \\
\mathrm{EV}\end{array}$ & 58 \\
\hline $\mathrm{M}$ & \multirow[t]{2}{*}{$\begin{array}{l}\text { Habitat Inventory and } \\
\text { Monitoring }\end{array}$} & \multirow[t]{2}{*}{$\begin{array}{l}\text { ODFW, 1999, Oregon Wildlife } \\
\text { Diversity Plan }\end{array}$} & \multirow[t]{2}{*}{$\begin{array}{l}\text { Identify and monitor habitats } \\
\text { needed to maintain Oregon's } \\
\text { wildlife diversity }\end{array}$} & $\begin{array}{l}\text { Determine quantity, distribution, and } \\
\text { condition of dominant plant } \\
\text { communities and major habitat } \\
\text { elements }\end{array}$ & NG & EV & 46 \\
\hline $\mathrm{M}$ & & & & Monitor changes and trends in habitats & NG & ST & 46 \\
\hline $\mathrm{M}$ & Stream morphology & $\begin{array}{l}\text { Forest Service, 1991, Land \& } \\
\text { Resource Management Plan, } \\
\text { Ochoco National Forest }\end{array}$ & $\begin{array}{l}\text { Maintain or show improvement } \\
\text { in stream conditions. }\end{array}$ & $\begin{array}{l}\text { Survey stream morphology using } \\
\text { established survey points on selected } \\
\text { streams }\end{array}$ & A5 & ST & 59 \\
\hline M & \multirow[b]{2}{*}{ Vegetation Condition } & \multirow{2}{*}{$\begin{array}{l}\text { Forest Service, 1996, UDR } \\
\text { Comprehensive Management } \\
\text { Plan }\end{array}$} & $\begin{array}{l}\text { Determine changes in amount } \\
\text { and condition of aquatic } \\
\text { vegetation }\end{array}$ & $\begin{array}{l}\text { USFS complete as part of fish habitat } \\
\text { monitoring, also correlate with flow } \\
\text { levels. }\end{array}$ & NG & $\begin{array}{l}\text { EV, } \\
\text { ST }\end{array}$ & 62 \\
\hline $\mathrm{M}$ & & & $\begin{array}{l}\text { Determine changes in amount } \\
\text { and condition of riparian } \\
\text { vegetation }\end{array}$ & $\begin{array}{l}\text { USFS, ODFW complete comparisons } \\
\text { using aerial photos during monitoring } \\
\text { for channel morphology and fish } \\
\text { habitat }\end{array}$ & A2-5 & $\begin{array}{l}\text { EV, } \\
\text { ST }\end{array}$ & 62 \\
\hline $\mathrm{M}$ & Riparian Vegetation & $\begin{array}{l}\text { BLM and Forest Service, 1992, } \\
\text { Middle Deschutes/Lower } \\
\text { Crooked Management Plan }\end{array}$ & $\begin{array}{l}\text { Riparian Vegetation-Maintain } \\
\text { or enhance functioning and } \\
\text { ecological condition. } \\
\text { Determine baseline level first }\end{array}$ & $\begin{array}{l}\text { Conduct inventories (including } \\
\text { infra-red photos). }\end{array}$ & $\begin{array}{l}\text { A3 } \\
\text { A5 }\end{array}$ & $\mathrm{CO}$ & 65 \\
\hline
\end{tabular}


Table A-1. Water-quality monitoring objectives and recommendations from previous management plans, by topic, and their proposed priority for coordinated longterm monitoring in the upper and middle Deschutes River Basin-Continued

[Note that proposed priorities only apply to interagency, coordinated monitoring and do not reflect the importance of a specific issue locally, or the needs of specific agencies. CRITFC, Columbia River IntertribalIntertribal Fish Commission; ODFW, Oregon Department of Fish and Wildlife; OWRD, Oregon Water Resources Department; BLM, Bureau of Land Management; USFS, U.S. Forest Service; WQ, water quality; temp., temperature; TSS, total suspended solids; turb., turbidity; LDR, Little Deschutes River; ab, above; Br, Bridge; DR, Deschutes River; blw, below; UDB, Upper Deschutes Basin; $\mathrm{ft}^{3}$ /s, cubic feet per second; IGDO, Intergravel Dissolved Oxygen; NG, None given; FREQUENCY DEFINITIONS: C, continuous; W, Weekly; Q, quarterly; A, annual; AN, every $N$ years; O, one time effort; E, Evaluate frequency after testing effectiveness; V, Varies according to project specific details; MONITORING TYPE DEFINITIONS: ST, Status \& Trends, CO, Compliance, EV, Evaluation; RE, Reconnaissance; <, less than; >, greater than; $\geq$, greater than or equal to; Reference number, numbered citations in Reference section]

\begin{tabular}{|c|c|c|c|c|c|c|c|}
\hline 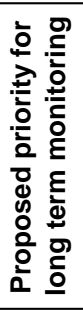 & Water issue & Entity & Monitoring objective & Recommended monitoring & 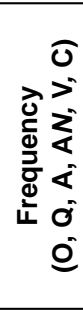 & 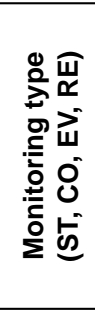 & 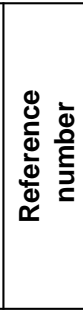 \\
\hline \multicolumn{8}{|c|}{ Channel Morphology and Habitat Related Monitoring-Continued } \\
\hline $\mathrm{M}$ & \multirow{7}{*}{$\begin{array}{l}\text { Riparian Habitat- } \\
\text { Interim Riparian Management } \\
\text { Objectives (RMO's) }\end{array}$} & \multirow{7}{*}{$\begin{array}{l}\text { Forest Service, 1995, Inland } \\
\text { Native Fish Strategy } \\
\text { Environmental Assessment }\end{array}$} & $\begin{array}{l}\text { Pool Frequencies -Maintain } \\
\text { according to channel widths, as } \\
\text { defined in Environmental } \\
\text { Assessment (EA) }\end{array}$ & $\mathrm{NG}^{\mathrm{h}}$ & NG & $\begin{array}{l}\mathrm{EV} \\
\mathrm{CO} ?\end{array}$ & 61 \\
\hline $\mathrm{H}$ & & & $\begin{array}{l}\text { Water Temperature-Maintain } \\
\text { to standards as specified in EA }\end{array}$ & $\mathrm{NG}^{\mathrm{h}}$ & NG & $\begin{array}{l}\mathrm{EV}, \\
\mathrm{CO} ?\end{array}$ & 61 \\
\hline $\mathrm{M}$ & & & $\begin{array}{l}\text { Large Woody Debris (forested } \\
\text { systems) -Maintain as } \\
\text { specified in EA }\end{array}$ & $\mathrm{NG}^{\mathrm{h}}$ & NG & $\begin{array}{l}\mathrm{EV} \\
\mathrm{CO} ?\end{array}$ & 61 \\
\hline $\mathrm{M}$ & & & $\begin{array}{l}\text { Bank stability (nonforested } \\
\text { systems)-Maintain } 80 \text { percent } \\
\text { stable }\end{array}$ & $\mathrm{NG}^{\mathrm{h}}$ & NG & $\begin{array}{l}\mathrm{EV} \\
\mathrm{CO}\end{array}$ & 61 \\
\hline M & & & $\begin{array}{l}\text { Lower Bank Angle } \\
\text { (nonforested systems)_- } \\
\text { Maintain } 75 \text { percent of banks } \\
\text { with }<90 \text { degree angle } \\
\text { (undercut) }\end{array}$ & $\mathrm{NG}^{\mathrm{h}}$ & NG & $\begin{array}{l}\mathrm{EV}, \\
\mathrm{CO} ?\end{array}$ & 61 \\
\hline M & & & $\begin{array}{l}\text { Width/Depth Ratio-Maintain } \\
<10\end{array}$ & $\mathrm{NG}^{\mathrm{h}}$ & NG & $\begin{array}{l}\mathrm{EV} \\
\mathrm{CO} ?\end{array}$ & 61 \\
\hline $\mathrm{M}$ & & & $\begin{array}{l}\text { Riparian Habitat Conservation } \\
\text { Areas (RHCA's) - Maintain } \\
\text { widths and manage according } \\
\text { to stream types as specified in } \\
\text { EA }\end{array}$ & $\mathrm{NG}^{\mathrm{h}}$ & $\mathrm{NG}$ & $\begin{array}{l}\mathrm{EV}, \\
\mathrm{CO} ?\end{array}$ & 61 \\
\hline $\mathrm{M}$ & $\begin{array}{l}\text { Water Quality- } \\
\text { Stream shading }\end{array}$ & $\begin{array}{l}\text { CRITFC, 1996, Columbia } \\
\text { River anadromous fish } \\
\text { restoration plan }\end{array}$ & $\begin{array}{l}\text { Maintain according to land } \\
\text { management standards (no } \\
\text { numeric standard) }\end{array}$ & NG & NG & $\begin{array}{l}\mathrm{EV}, \\
\mathrm{CO}\end{array}$ & 7 \\
\hline
\end{tabular}


Table A-1. Water-quality monitoring objectives and recommendations from previous management plans, by topic, and their proposed priority for coordinated longterm monitoring in the upper and middle Deschutes River Basin-Continued

[Note that proposed priorities only apply to interagency, coordinated monitoring and do not reflect the importance of a specific issue locally, or the needs of specific agencies. CRITFC, Columbia River IntertribalIntertribal Fish Commission; ODFW, Oregon Department of Fish and Wildlife; OWRD, Oregon Water Resources Department; BLM, Bureau of Land Management; USFS, U.S. Forest Service; WQ, water quality; temp., temperature; TSS, total suspended solids; turb., turbidity; LDR, Little Deschutes River; ab, above; Br, Bridge; DR, Deschutes River; blw, below; UDB, Upper Deschutes Basin; $\mathrm{ft}^{3} / \mathrm{s}$, cubic feet per second; IGDO, Intergravel Dissolved Oxygen; NG, None given; FREQUENCY DEFINITIONS: C, continuous; W, Weekly; Q, quarterly; A, annual; AN, every $N$ years; O, one time effort; E, Evaluate frequency after testing effectiveness; V, Varies according to project specific details; MONITORING TYPE DEFINITIONS: ST, Status \& Trends, CO, Compliance, EV, Evaluation; RE, Reconnaissance; <, less than; >, greater than; $\geq$, greater than or equal to; Reference number, numbered citations in Reference section]

\begin{tabular}{|c|c|c|c|c|c|c|c|}
\hline 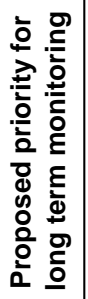 & Water issue & Entity & Monitoring objective & Recommended monitoring & 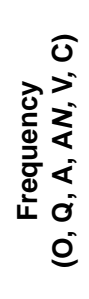 & 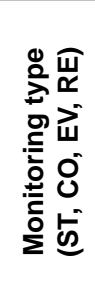 & 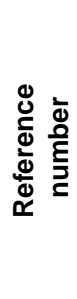 \\
\hline \multicolumn{8}{|c|}{ Aquatic Biota } \\
\hline $\mathrm{L}$ & Fish Populations & $\begin{array}{l}\text { Forest Service, 1996, UDR } \\
\text { Comprehensive Management } \\
\text { Plan }\end{array}$ & $\begin{array}{l}\text { Determine fish population } \\
\text { trends }\end{array}$ & $\begin{array}{l}\text { ODFW measure spawner abundance by } \\
\text { redd counts }\end{array}$ & $\mathrm{A}$ & $\begin{array}{l}\text { ST, } \\
\text { EV }\end{array}$ & 62 \\
\hline $\mathrm{M}$ & $\begin{array}{l}\text { Aquatic Sediment- } \\
\text { Macroinvertebrates }\end{array}$ & $\begin{array}{l}\text { Forest Service, 1990, Land \& } \\
\text { Resource Management Plan, } \\
\text { Deschutes National Forest }\end{array}$ & $\begin{array}{l}\text { Maintain }<20 \text { percent negative } \\
\text { change in abundance of good } \\
\text { water-quality indicator species } \\
\text { (mayflies, stoneflies) }^{\mathrm{e}}\end{array}$ & $\begin{array}{l}\text { Perform macroinvertebrate population } \\
\text { trend analysis (no specific methods } \\
\text { given) at indicator streams and river } \\
\text { segments }\end{array}$ & A2 & $\begin{array}{l}\mathrm{CO} \\
\mathrm{EV}\end{array}$ & 58 \\
\hline $\mathrm{L}$ & \multirow[t]{2}{*}{ Species Populations } & \multirow{2}{*}{$\begin{array}{l}\text { ODFW, 1999, Oregon Wildlife } \\
\text { Diversity Plan }\end{array}$} & \multirow{2}{*}{$\begin{array}{l}\text { Assess, conserve, and } \\
\text { enhance populations of native } \\
\text { species at self-sustaining } \\
\text { levels throughout their } \\
\text { natural geographic range }\end{array}$} & $\begin{array}{l}\text { Monitor populations of threatened, } \\
\text { endangered, and other species requiring } \\
\text { special management attention }\end{array}$ & NG & ST & 46 \\
\hline $\mathrm{L}$ & & & & $\begin{array}{l}\text { Monitor populations of common } \\
\text { species }\end{array}$ & NG & ST & 46 \\
\hline $\mathrm{L}$ & $\begin{array}{l}\text { Macroinvertebrate } \\
\text { Community Structure }\end{array}$ & $\begin{array}{l}\text { Forest Service, 1996, UDR } \\
\text { Comprehensive Management } \\
\text { Plan }\end{array}$ & $\begin{array}{l}\text { Determine short-term changes } \\
\text { in water-quality and long-term } \\
\text { trends in fish food supply }\end{array}$ & $\begin{array}{l}\text { Sample macroinvertebrates at } 3 \text { stations } \\
\text { (Bull Bend, Besson, Meadow) }\end{array}$ & A2 & ST & 62 \\
\hline
\end{tabular}

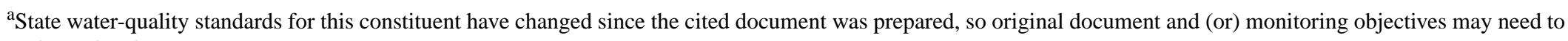
be updated.

${ }^{\mathrm{b}}$ See ODEQ for relevant standards.

${ }^{\mathrm{c}}$ No sampling or monitoring locations specified.

${ }^{\mathrm{d}}$ Although issue may be of high priority, the monitoring indicated is short term, limited in space, and is project oriented. It therefore may fall outside the scope of regional monitoring. Agencies conduct project specific monitoring.

${ }^{\text {e}}$ Specific water bodies and locations defined in Appendix 11 of Forest Plan.

${ }_{\mathrm{f}}$ Measure annually for first 5 years, then every 3 years thereafter.

${ }^{\mathrm{g}}$ Important water bodies defined in Appendix 13 of Forest Plan.

${ }^{\mathrm{h}}$ Monitoring of activities affecting Riparian Habitat Conservation Areas (RHCA's) are determined on a case-by-case basis after completion of a screening test. Refers to PACFISH, section 7 for baseline values. 


\section{APPENDIX B. QUALITY-ASSURANCE TERMS}

Quality-assurance (QA) programs will be critical to the success of monitoring. Good quality- control (QC) data, and assessments of those data, can allow the comparison of data among agencies and over time, whereas poor quality-control data can prevent such comparisons. Final development of QA plans will not be possible until additional monitoring decisions have been made. As part of the implementation of the Monitoring Plan, detailed QA plans will need to be developed and put into practice as appropriate for each component of the plan, based on the principles outlined previously. It is the goal of all QA programs to provide environmental data, using multiple sampling crews and analytical laboratories, that have quantifiable bias, variability, and representativeness, along with detection levels that will allow all data to be comparable within a single dataset and a quality to meet the objectives of the monitoring plan.The following presents a generalized description of important elements and aspects of quality assurance.

There are three facets to any quality-assurance program of a monitoring plan. They are (1) qualityassurance elements, (2) quality-control data, and (3) quality assessment. These are the planned and systematic procedures necessary to provide adequate confidence that monitoring data will satisfy established requirements for quality.

Quality-Assurance elements are the procedures used to control those unmeasurable components of a monitoring program, such as sampling the wrong site or area, sampling at the wrong time, using the wrong sampling equipment or materials, applying an inappropriate method or sequence of procedures for sample processing or sample analysis, and sample switching or incorrectly identifying samples. Examples of QA elements include work plans identifying sampling locations and times, and protocols specifying equipment, sample processing and analytical methods, and supplies. Protocols may become standard operating procedures to establish adequate data quality. Examples of the types of activities that could be included in these elements are: ensuring that maintenance logs and calibration records are available for every scientific instrument, specifying the type of materials acceptable for equipment and supplies, and ensuring that the monitoring protocols are followed. Although not measurable, many monitoring decisions and processes can be controlled through application of QA elements.

Quality-Control data are the data generated to estimate the magnitude of bias, variability and representativeness in processes for obtaining environmental data. These processes include field processes of sample collection, field processing, shipping, storage, and laboratory analysis.

Quality Assessment is the overall process of assessing the quality of the environmental data by reviewing (1) the application of the QA elements and (2) the analysis of the QC data. Quality assessment encompasses both the measurable and unmeasurable factors affecting the quality of the environmental data. Assessment of these factors may indicate limitations that require modifications to protocols or to standard operating procedures for sample collection and analysis or affect the desired interpretation and use of the environmental data.

Definitions of terms used in this Monitoring Plan are provided below. It is suggested that assessments and reports for the plan use these same terms when discussing QA/QC procedures.

Bias-A systematic error inherent in a method or caused by some artifact or idiosyncrasy of the measurement system. Bias may be either positive or negative.

Variability - The degree of variation in independent measurements as the result of repeated application of the process under specific conditions.

Accuracy - The degree of agreement of a measured value with the true or expected value of the quality concern.

Precision-The degree of mutual agreement characteristic of independent measurements as a result of repeated application of the process under specified conditions. 
Representativeness - A measure of how well a point of measurement is representative of a crosssectional average normalized for discharge or velocity.

Completeness-A measure of the data collected, compared to the data identified for collection in the monitoring plan.

Detection limits-A minimum concentration or value for which a constituent can be measured with known reliability.

Precision is inversely related to variability (the greater the variability, the smaller the precision). Accuracy is a measure that incorporates both bias and variability.

The Monitoring Plan is designed to answer specific questions that have been established by the plan objectives. QC data are used to estimate the bias and (or) variability of environmental data. The QC sampling program should, therefore, help to (1) qualify the interpretation of the environmental data and (2) to identify the sources and magnitude of bias or variability in the environmental data. Examples of QC samples are listed below:

Field blanks measure contamination in the sampling, field processing, shipping, holding area, and analytical method. Contamination biases sample results.

Laboratory blanks measure sources of contamination in the laboratory.

Field blind standards/reference material measure bias due to field processing, shipping, holding area, and analytical method. Standards are best used to measure bias between different laboratories because the quantity of chemical in the sample is known (avoids the finger pointing exercise). Multiple uses of a standard can be used to measure variability.

Laboratory standards/reference material verify rating curves of analytical methods.

Field spikes determine if field spiking, shipping, storing, or analytical methods used can recover the quantity of spike added. To use this sample, the concentration in the environmental sample must be known. This QC sample detects matrix interferences, breakdown of chemicals between time of spiking and analysis, and other processes that can result in gains or losses of contaminants. When standards are not in the concentration range of interest, this may be used to supplement standards. Differences between laboratory spikes and field spikes can identify chemicals that are breaking down between the times of spiking in the field and spiking in the laboratory. Multiple field spikes sometimes can be more useful when measuring variability if most of the contaminants of interest are at concentrations less than the detection limit.

Field splits determine variability due to the field processing, shipping, holding, and analysis after splitting or if there is a bias between laboratories. It should be recognized that if two laboratories have differing answers, the true answer is not known, only the difference between the two results. (See field blind standards above).

Laboratory splits measure variability in the laboratory.

Field concurrent replicates measure variability due to sampling, field processing, shipping, storing, and analysis.

Cross-section sampling and point sampling determine how representative a single sample is of the whole river. A depth and width integrated isokinetic (velocity weighted) sampling of the cross section (Wilde and others., 1999) is the preferred sampling field procedure for suspended material. When the concentration of suspended material is small or the constituents of interest are not affected by suspended material, depth and width integrated sampling is less important. When there is a long reach (25- to 100-foot widths, depending on the depth of stream and roughness of channel) with no significant input of new waters or contaminants, a single sample at the centroid 
of the stream may be representative. For long-term monitoring of a fixed station over many years, it may be cost efficient to determine if a stream is mixed during various hydrologic conditions so as to allow single point sampling rather than the more expensive cross-section composite sampling each time. For example, the Washington Department of Ecology determined for total suspended solids that the error in the Yakima River was minimal and that single-point depth-integrated sampling data were comparable with data from cross-sectional composited samples (Joy and Patterson, 1997).

For more information on QC samples and their use, see Wilde and others (1999) and Horowitz and others (1994). 

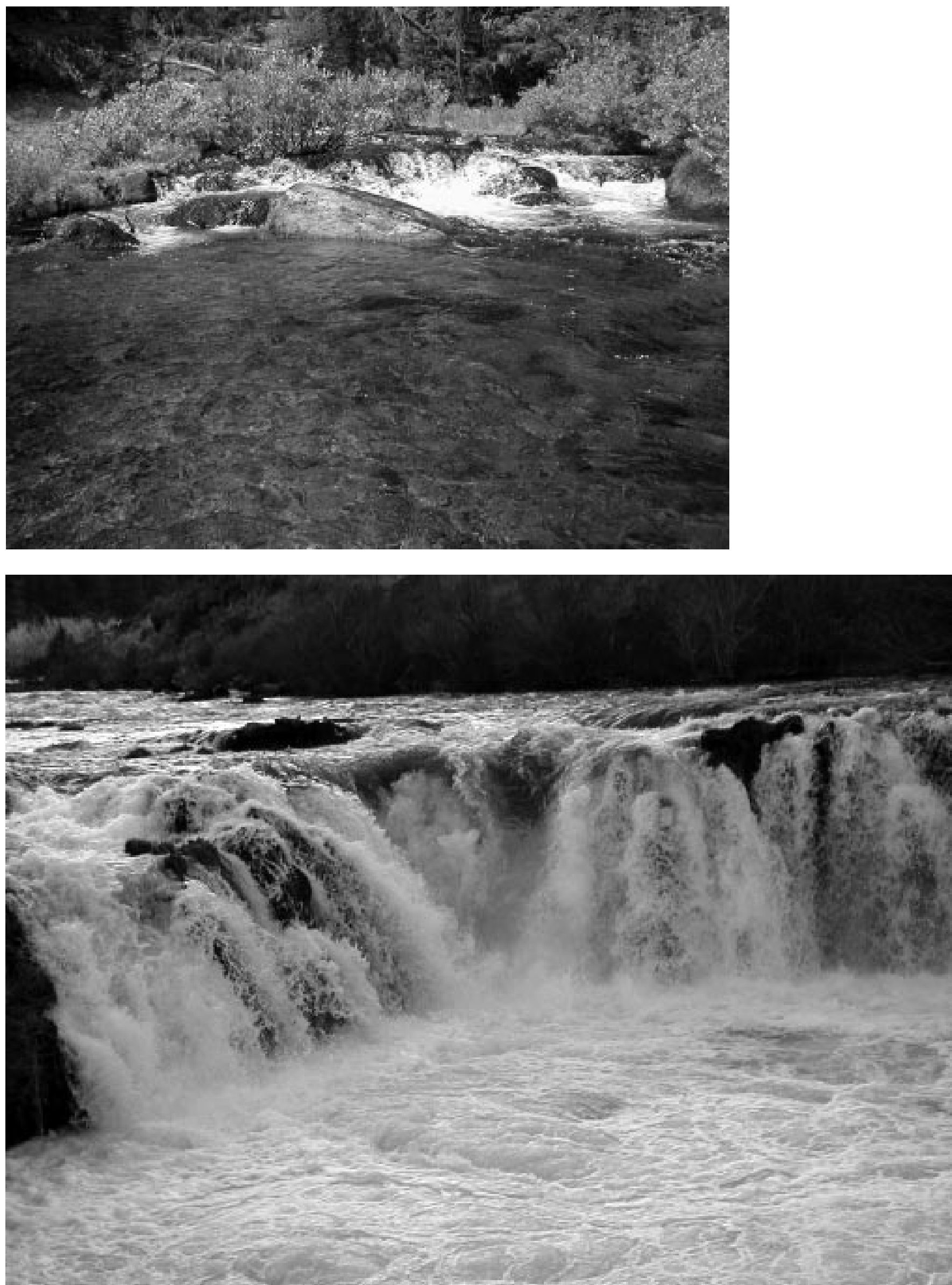